УДК 8:372.8

ISSN 2500-2953

Rhema. Рема

3.2018

УЧРЕДИТЕЛЬ:

Издается с 2002 г.

Московский

педагогический

государственный

университет

Выходит 4 раза в год

ПИ № ФС 77-67769

Подписной индекс журнала

от 17.11.2016 г.

по Объединенному каталогу

«Пресса России»- 85006

Адрес редакции:

Сайт: rhema-journal.com

109240, Москва,

E-mail: rhema.pema@gmail.com

ул. В. Радищевская,

д. 16-18, комн. 223

(C) МПГУ, 2018 


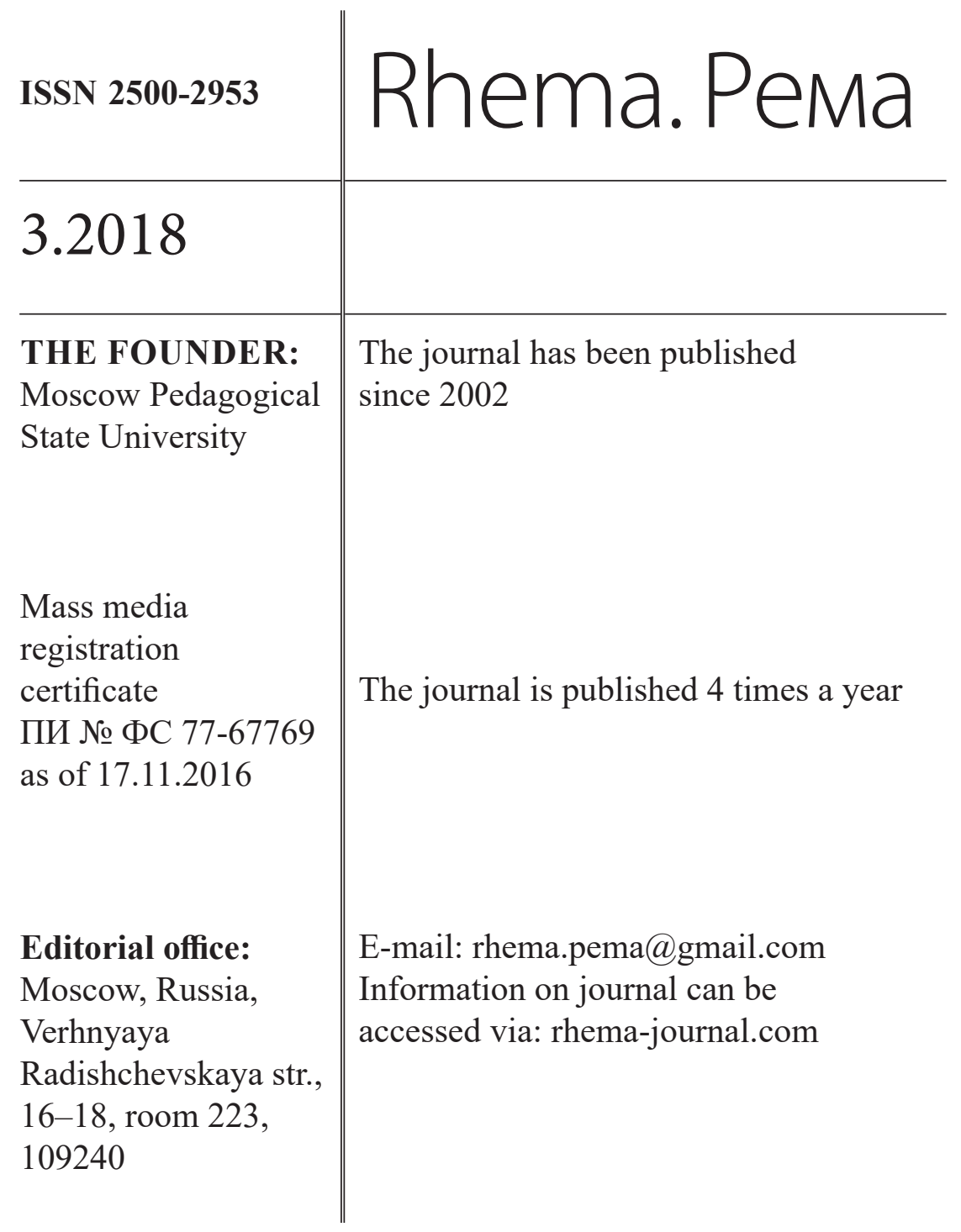

(C) МПГУ, 2018 


\section{Редакционная коллегия}

\section{Главный редактор}

Антон Владимирович Циммерлинг - доктор филологических наук; научный руководитель Института современных лингвистических исследований Московского педагогического государственного университета; профессор кафедры общего языкознания и русского языка Государственного института русского языка имени А.С. Пушкина; профессор кафедры компьютерной лингвистики и формальных моделей языка Московского педагогического государственного университета; ведущий научный сотрудник сектора типологии Института языкознания РАН.

\section{Заместитель главного редактора}

Екатерина Анатольевна Лютикова - доктор филологических наук, доцент; доцент кафедры теоретической и прикладной лингвистики филологического факультета МГУ имени М.В. Ломоносова; заведующая лабораторией общей лингвистики и теории грамматики Института современных лингвистических исследований, профессор кафедры компьютерной лингвистики и формальных моделей языка Московского педагогического государственного университета.

\section{Ответственный секретарь}

Павел Валерьевич Гращенков - доктор филологических наук; доцент кафедры теоретической и прикладной лингвистики филологического факультета МГУ имени М.В. Ломоносова; старший научный сотрудник отдела языков народов Азии и Африки Института востоковедения РАН; старший научный сотрудник лаборатории общей лингвистики и теории грамматики Института современных лингвистических исследований Московского педагогического государственного университета.

Татьяна Михайловна Воителева - доктор педагогических наук, професcop; профессор кафедры методики преподавания русского языка и литературы Московского государственного областного университета.

Наталья Дмитриевна Гальскова - доктор педагогических наук, профессор; профессор кафедры лингводидактики Московского государственного областного университета.

Елена Валентиновна Гетманская - доктор педагогических наук; профессор кафедры методики преподавания литературы Института филологии Московского педагогического государственного университета.

Атле Грённ - профессор кафедры литературы, страноведения и европейских языков Университета Осло, Норвегия.

Сурен Тигранович Золян - доктор филологических наук, профессор; ведущий научный сотрудник отдела теоретической философии Института философии, социологии и права Национальной Академии наук Армении, г. Ереван, Армения; профессор Института гуманитарных наук Балтийского федерального университета имени Иммануила Канта, г. Калининград, Россия.

Илона Кишш - PhD (филология); главный редактор журнала «Русский квартал» Будапештского университета имени Лоранда Этвёша, Венгрия; профессор кафедры всемирной литературы Института филологии Московского педагогического государственного университета; старший научный сотрудник Института перспективных исследований Московского педагогического государственного университета. 


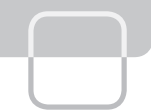

Алексей Александрович Коренев - кандидат педагогических наук, старший преподаватель кафедры теории преподавания иностранных языков факультета иностранных языков и регионоведения МГУ имени М.В. Ломоносова.

Павел Лавринец - доктор гуманитарных наук, доцент; заведующий кафедрой русской филологии Вильнюсского университета, Литва.

Анатолий Симонович Либерман - доктор филологических наук; профессор кафедры немецкого, нидерландского и скандинавских языков Университета Миннесоты, г. Миннеаполис, США.

Сильвия Лураги - профессор факультета гуманитарных наук, Университет Павии, Италия.

Михаил Николаевич Михайлов - $\mathrm{PhD}$ (филология); профессор переводоведения (русский и финский языки) Института языков, перевода и литературы Университета Тампере, Финляндия.

Игорь Алексеевич Пильщиков - доктор филологических наук; ведущий научный сотрудник Института мировой культуры МГУ имени М.В. Ломоносова; главный редактор Фундаментальной электронной библиотеки «Русская литература и фольклор», г. Москва, Россия.

Нерея Мадарьяга Писано - PhD (филология); доцент кафедры классических языков (секция славянской филологии) Университета Страны Басков, г. Витория, Испания.

Владимир Александрович Плунгян - доктор филологических наук, профессор, академик РАН; заместитель директора Института русского языка им. В.В. Виноградова РАН; заведующий сектором типологии Института языкознания РАН; профессор кафедры теоретической и прикладной лингвистики МГУ имени М.В.Ломоносова.

Велка Александрова Попова - кандидат филологических наук; доцент кафедры болгарского языка, сотрудник лаборатории прикладной лингвистики факультета гуманитарных наук Шуменского университета имени Епископа Константина Преславского, Болгария.

Наталья Вадимовна Сердобольская - кандидат филологических наук; доцент Учебно-научного центра лингвистической типологии Института лингвистики Российского государственного гуманитарного университета; заведующая лабораторией лингвистической типологии Института современных лингвистических исследований Московского педагогического государственного университета.

Андрей Стоянович - доктор филологических наук, профессор; заведующий кафедрой иностранных языков Белградского университета, Сербия.

Младен Ухлик - доктор филологических наук, профессор; заведующий кафедрой русского языка Отделения славянских языков философского факультета Университета Любляны, Словения.

Александр Иосифович Федута - доктор филологических наук; редактор биографического альманаха «Асоба і час» («Личность и время»), г. Минск, Республика Беларусь.

Любовь Георгиевна Чапаева - доктор филологических наук; профессор кафедры общего и прикладного языкознания Московского педагогического государственного университета. 


\section{Editorial Board}

\section{Editor-in-Chief}

Anton V. Zimmerling - Dr. Phil. Hab.; head of the Institute for Modern Linguistic Research, Moscow Pedagogical State University; principal research fellow at the Institute of Linguistics, Russian Academy of Sciences; professor at the Department of General Linguistics and Russian Language, Pushkin State Russian Language; professor at the Department of Computational Linguistics and Formal Models of Language, Moscow Pedagogical State University.

\section{Deputy chief editor}

Ekaterina A. Lyutikova - Dr. Phil. Hab.; associate professor at the Department of Theoretical and Applied Linguistics, Lomonosov Moscow State University; head of the Laboratory of General Linguistics and Grammatical Theory, Institute for Modern Linguistic Research, professor at the Department of Computational Linguistics and Formal Models of Language, Moscow Pedagogical State University.

\section{Executive secretary}

Pavel V. Grashchenkov - Dr. Phil. Hab.; associate professor at the Department of Theoretical and Applied Linguistics, Faculty of Philology, Lomonosov Moscow State University; research fellow at the Institute of Oriental Studies, Russian Academy of Sciences; senior research fellow of the Laboratory of General Linguistics and Grammatical Theory, Institute for Modern Linguistic Research, Moscow Pedagogical State University.

Lyubov G. Chapaeva - Dr. Phil. Hab; professor at the Department of General and Applied Linguistics, Institute of Philology and Foreign languages, Moscow Pedagogical State University.

Aleksandr Feduta - Dr. Phil. Hab.; editor-in-chief of the biographical almanac «Personality and Time», Minsk, Belarus.

Natalia D. Galskova - Dr. Ped. Hab.; professor at the Department of Linguodidactics, Moscow Region State University.

Elena V. Getmanskaya - Dr. Ped. Hab.; professor at the Department of Methods of Teaching Literature, Moscow Pedagogical State University.

Atle Grønn - Dr. Phil. Hab.; professor at ILOS - Department of Literature, Area Studies and European Languages, University of Oslo, Norway.

Ilona Kiss - PhD in Philology; chief editor of the Russian Quarter journal of Budapest Eötvös Loránd University; professor at the Department of the Worlds' Literatures, Moscow Pedagogical State University, senior fellow at the Russian Institute for Advanced Studies, Moscow Pedagogical State University.

Alexey A. Korenev - $\mathrm{PhD}$ in Pedagogy; senior lecturer at the Department of Foreign Language Teaching Theory, Faculty of Foreign Languages and Area Studies, Lomonosov Moscow State University.

Pavel Lavrinec - PhD in Philology; associate professor, head of the Department of Russian Philology, Vilnius University, Lithuania.

Anatoly Liberman - Dr. Phil. Hab.; professor at the Department of German, Dutch and Scandinavian, University of Minnesota, USA. 


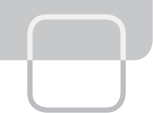

Silvia Luraghi - $\mathrm{PhD}$ in Philology; associate professor at the Department of Humanities, Section of General and Applied Linguistics, University of Pavia, Italy.

Mikhail Mikhailov - PhD in Philology; professor at the School of Language, Translation and Literary Studies, University of Tampere, Finland.

Igor A. Pilshikov - Dr. Phil. Hab.; senior research fellow at the Institute of the World Culture, Lomonosov Moscow State University; editor-in-chief of the Fundamental digital library «Russian literature and folklore».

Nerea Madariaga Pisano - $\mathrm{PhD}$ in Philology; associate professor at the Department of Classical Studies (Section of Slavic Philology), University of the Basque Country, Vitoria, Spain.

Vladimir A. Plungian - Dr. Phil. Hab., full member of the Russian Academy of Sciences; deputy director of the Vinogradov Institute of Russian Language, Russian Academy of Sciences; head of the Sector of Typology, Institute of linguistics, Russian Academy of Sciences; professor at the Department of Theoretical and Applied Linguistics, Lomonosov Moscow State University.

Velka A. Popova - PhD in Philology; associate professor at the Department of Bulgarian, research fellow at the Laboratory of Applied Linguistics, Faculty of Humanities, the Constantin of Preslav Bishop Shumen University, Bulgaria.

Natalia V. Serdobolskaya - PhD in Philology; associate professor at the Training and Research Center for Linguistic Typology, Institute of Linguistics, Russian State University for the Humanities; head of the Laboratory of Linguistic Typology, Institute for Modern Linguistic Research, Moscow Pedagogical State University.

Andrej Stojanović - Dr. Phil. Hab., full professor; head of the Department of Foreign Languages, University of Belgrade, Serbia.

Mladen Uhlik - Dr. Phil. Hab., professor; head of the Department of Russian, Institute of Slavic Languages, Faculty of Philosophy, University of Ljubljana, Slovenia.

Tatiana M. Voiteleva - Dr. Ped. Hab., professor at the Department of the Methods of Teaching Russian Language and Literature, Moscow Region State University.

Suren T. Zolyan - Dr. Phil. Hab., professor; leading research fellow at the Department of Theoretical Philosophy, Institute of Philosophy, Sociology and Law Studies, National Academy of Sciences, Yerevan, Armenia; professor at the Institute for the Humanities, Immanuel Kant Baltic Federal University, Kaliningrad, Russia. 


\section{Содержание № 3.2018}

\section{ФИЛОЛОГИЯ. ТЕКСТОЛОГИЯ}

\section{И.Б. Иткин}

Старый доктор в обветшалой тоге... :

об одном «неоконченном» стихотворении

Георгия Шенгели . . . . . . . . . . . . . . . . . . . . . . . . . . . . . .9

Е.В. Николаева

Переписка Л.Н. Толстого и Н.Н. Страхова . . . . . . . . . . . . . . . 15

И.В. Софронова

Поэтические особенности четверостиший

в литературе народов Поволжья . . . . . . . . . . . . . . . . . . . . . 39

\section{ЛИНГВИСТИКА}

\section{Е.Л. Рудницкая}

Особенности причастий

в современном эвенкийском устном языке

(по корпусу рассказов 2005-2011 гг.) . . . . . . . . . . . . . . . . . . . 49

A.H. Сахарусов

К вопросу об особенностях функционирования

швабского территориального диалекта

в официально-деловой сфере (анализ разговоров

во время радиодебатов в г. Штутгарт) . . . . . . . . . . . . . . . . . . 69

С.Г. Татевосов

Событийно-структурная морфология в ненецком языке . . . . . . . . 88

О.Д. Черепанова

Фонетические особенности немецкого и русского языков

через призму скороговорок . . . . . . . . . . . . . . . . . . . . . . . . . 119

\section{МЕТОДИКА}

\section{Н.В. Казанская}

Общие проблемы преподавания фонетики русского языка народам абхазо-адыгской группы: преодоление и устранение фонетической интерференции в условиях билингвизма . . . . . . . 136 


\section{PHILOLOGY AND TEXTOLOGY}

\section{I.B.Itkin}

"The old doctor in a decrepit toga...":

on an "unfinished" poem of Georgy Shengeli . . . . . . . . . . . . . . . .9

E.V. Nikolaeva

Correspondence of L.N. Tolstoy and N.N. Strakhov . . . . . . . . . . . . 15

I.V. Sofronova

Poetic features of the quatrains in the literature

of the peoples of the Volga region . . . . . . . . . . . . . . . 39

\section{LINGUISTICS}

\section{E.L. Rudnitskaya}

Special features of participles

in modern oral Evenki

(based on the corpus of oral stories from 2005-2011) . . . . . . . . . . 49

\section{A.N. Saharusov}

On functional characteristics of Swabian regional dialect

in the official area . . . . . . . . . . . . . . . . . . . . . . . . 69

S.G. Tatevosov

Event-structural morphology in Tundra Nenets . . . . . . . . . . . 88

O.D. Cherepanova

Contrastive phonetic analysis

of Russian and German tongue twisters . . . . . . . . . . . . . . . . . 119

\section{TEACHING THEORY}

\section{N.V. Kazanskaya}

General problems of teaching phonetics

of the Russian Language to Northwest Caucasian students:

Overcoming and eliminating phonetic interference

in the bilingual education conditions . . . . . . . . . . . . . . . 136 
Филология.

Текстология

10.31862/2500-2953-2018-3-9-14

\section{И.Б. Иткин}

Институт востоковедения РАН, 107031 г. Москва, Российская Федерация;

Школа лингвистики, Национальный исследовательский университет «Высшая школа экономики», 105066 г. Москва, Российская Федерация

\section{Старый доктор в обветшалой тоге... : об одном «неоконченном» Стихотворении Георгия Шенгели}

Настоящая заметка представляет собой дополнение к комментариям, включенным в I том вышедшего в 2017 г. двухтомного издания стихотворений и поэм Георгия Шенгели. Показано, что написанное в августе 1943 г. четверостишие «Старый доктор в обветшалой тоге...», которое составитель сборника рассматривает как неоконченное, в действительности представляет собой вполне целостный экспромт - переделку заключительной строфы стихотворения Николая Гумилева «Болонья». Выдвигается предположение о том, что первая строка четверостишия Шенгели содержит также отсылку к первой строке другого стихотворения Гумилева - «Заклинание». Рассматривается взаимосвязь между данным четверостишием и написанным Шенгели полтора месяца спустя стихотворением «В шаге легком и упругом...».

Ключевые слова: поэзия Георгия Шенгели, поэзия Николая Гумилева, реминисценции. 


\section{I.B. Itkin}

Institute of Oriental Studies, RAS, Moscow, 107031, Russian Federation;

School of Linguistics, National Research University "Higher School of Economics", Moscow, 105066, Russian Federation

\section{"The old doctor in a decrepit toga...": on an "unfinished" poem of Georgy Shengeli}

This small article is an addition to the commentaries included in the first volume of the two volume edition of rhymes and poems by Georgy Shengeli published in 2017. We show that the quatrain "Старый доктор в обветшалой тоге..." ("The old doctor in the decrepit toga...") written in August 1943, which the compiler of the volume regards as unfinished, is in a fact a quite holistic extempore rhyme - the remake of a final strophe of Nikolay Gumilyov's rhyme "Bologna". We bring forward the hypothesis that the first line of the Shengeli's quatrain contains an allusion to the first line of another Gumilyov's rhyme "The spell" and we examine the connection between this quatrain and the rhyme "В шаге легком и упругом..." ("In the light and springy stride...") written a month and a half later.

Key words: Georgy Shengeli's poetry, Nikolay Gumilyov's poetry, reminiscentia.

Выход двухтомника «Стихотворения и поэмы», включающего в себя наряду с хорошо известными множество неопубликованных или разбросанных по труднодоступным периодическим изданиям произведений яркого поэта, блестящего переводчика и замечательного ученого-стиховеда Георгия Аркадьевича Шенгели (1894-1956) [Шенгели, 2017], представляет собой заметное событие как для любителей поэзии, так и для литературоведов.

Всесторонняя оценка этого труда с точки зрения полноты, текстологической точности, критического аппарата и т.д., безусловно, должна быть делом специалистов как непосредственно по творчеству Георгия Шенгели, так и по истории русской литературы первой половины XX в. Мы ни в коем случае не относим себя ни к тем, ни к другим, однако о некоторых аспектах работы составителя и комментатора сборника В.А. Резвого, как представляется, вправе судить и неспециалист. 
Так, комментарии к I тому занимают более 100 страниц [Шенгели, 2017, c. 610-723]: цифра, внушающая уважение. Тем не менее, при чтении книги бросается в глаза, что комментатор уделяет явно недостаточно внимания разного рода цитатам и аллюзиям, встречающимся во многих стихотворениях. Конечно, какие-то пояснения на этот счет в комментариях даются, но нет сомнений, что применительно к Георгию Шенгели - поэту подчеркнуто «литературному» и «книжному» - их должно было бы быть существенно больше. Отсутствие же таких пояснений не только значительно обедняет читательское восприятие многих произведений, но и иногда служит основой для прямо неверных выводов. В настоящей заметке мы позволим себе ограничиться одним, но чрезвычайно ярким примером.

В I томе двухтомника впервые опубликовано (по автографу, хранящемуся в Российском государственном архиве литературы и искусства) следующее стихотворение:

$$
* * *
$$

Старый доктор в обветшалой тоге:

Ничего уже ему не надо,

Но и он порой волочит ноги

По весельмм стогнам Ашхабада.

$$
<11 . \text { III.1943> [Шенгели, 2017, с. 580] }
$$

В.А. Резвый относит это стихотворение в раздел «Неоконченное». На наш взгляд, это решение выглядит спорным даже само по себе: приведенное четверостишие явно обладает смысловой завершенностью. Однако главная причина, по которой «Старый доктор...» никак не может считаться неоконченным, лежит не в плоскости субъективных оценок. Четверостишие Шенгели представляет собой вариацию (причем вариацию, очень близкую к исходному тексту) заключительной строфы стихотворения Николая Гумилева «Болонья» $(<1913>$; вошло в сборник «Колчан» (1916)):

Старый доктор сгорблен в красной тоге,

Он законов ищет в беззаконьи,

Но и он порой волочит ноги

По веселым улииам Болоньи.

Четверостишие Шенгели - мрачно-иронический автопортрет в первые дни после приезда поэта в Ашхабад, где он жил с августа 1943 по октябрь 1944 г. [Шенгели, 2017, с. 680]. 11 августа поэт включил это стихотворение в письмо жене, Нине Леонтьевне Манухиной [Там же, с. 722], разумеется, нисколько не сомневаясь, что та узнает цитату. 
На этом можно было бы поставить точку, однако работа Шенгели над исходным текстом Гумилева, как кажется, обнаруживает самостоятельный интерес. Рассмотрим ход этой работы от конца четверостишия к его началу.

В четвертой строке биографически необходимая замена Болоньи на Ашхабад потребовала отказа от слова улищы. Выбранное Шенгели слово стогны - одно из немногих, подходящих по размеру и смыслу, попутно создает комический эффект своей архаичностью.

Третья строка осталась дословно той же.

Вторая строка нуждалась в переделке не только в связи с изменившейся рифмой, но и по содержанию (в стихотворении Гумилева речь идет о докторе права, т.е. о юристе, которым Шенгели не был). Слова Ничего уже ему не надо свидетельствуют едва ли не об отчаянии; к счастью, в таком состоянии поэт, по-видимому, пребывал недолго (см. ниже).

Что касается первой строки, то Шенгели отредактировал ее неожиданно сильно. Теоретически он мог вообще никак ее не менять, если же ему важно было подчеркнуть непритязательность своего эвакуационного одеяния, вполне подошло бы нечто вроде «Старый доктор сгорблен в ветхой тоге...». Между тем Шенгели счел нужным вообще исключить из этой строки предикат, так что вся конструкция приобрела легкий налет аграмматичности, который поэт постарался смягчить двоеточием.

Конечно, Шенгели мог выбрать для первой строки своего экспромта именно этот вид «просто так»; более того, нельзя даже исключать, что он неточно помнил текст Гумилева и считал, что сохраняет в неизменном виде обе нечетных строки. Мы, однако, предполагаем, что поэт придал этой строке такую структуру вполне осознанно - с целью сделать ее полностью изоморфной первой строке более раннего стихотворения Гумилева «Заклинание» (<1907>; вошло в сборник «Романтические цветы» (1908)): Юный маг в пурпуровом хитоне. Если это действительно так, предпринятая Шенгели литературная игра приобретает дополнительную глубину и блеск: путем одновременной отсылки к двум разным стихотворениям Гумилева поэт смог выразить не только очевидный смысл «Я бедный, состарившийся, уставший от жизни человек», но и другой, не столь лежащий на поверхности: «Когда-то я был молодым прекрасным волшебником».

...27 сентября 1943 г. Шенгели пишет на ашхабадскую тему еще одно стихотворение: 


$$
* * *
$$

В шаге легком и упругом

По сухому камню плит

К жизни вызванная югом

Снова молодость звенит.

Мне опять остро и быстро, Метко, пристально, светло; Мне опять бряцанье систра Бронзы в голос налило.

Синевой изюмной сизо

По ущельям осиян, Древний кряж Паропамиза

Стонет арфами парфян.

Впрочем, нет; парфян не надо:

Хорошо мне и без них

Здесь, на стогнах Ашхабада,

Разгрызать весельй стих.

Жаркий полдень дунул мелом

В каждый китель, в каждый дом:

Люди в белом, город в белом,

Только небо в голубом.

[Шенгели, 2017, с. 493-494] ${ }^{1}$

Это стихотворение, особенно его первая и четвертая строфы, выглядит как развернутый, «по пунктам», ответ самому себе на четверостишие полуторамесячной давности. Вместо неспешного пятистопного хорея - стремительный четырехстопный. Вместо Старый доктор... Снова молодость звенит. Вместо волочит ноги - В шаге легком и упругом.... Вместо Ничего уже ему не надо - Хорошо мне.. разгрызать весельй стих ${ }^{2}$. Стогны Аихабада, изначально выступавшие просто как замена улиц Болоньи, в новом стихотворении приобретают вполне самостоятельную ценность. Гумилевский эпитет весельй, в августовском экспромте выглядевший откровенно издевательски, теперь относится к стиху и употреблен совершенно всерьез.

${ }^{1}$ Выражаю искреннюю благодарность И.А. Пильщикову, обратившему мое внимание на связь между этим стихотворением и стихотворением «Старый доктор сгорблен в красной тоге...». В комментариях к I тому «Стихотворений и поэм» наличие такой связи не отмечено.

${ }^{2}$ Под «разгрызанием стиха», возможно, имеется в виду работа по изучению туркменского стихосложения: во время своего пребывания в Ашхабаде Шенгели написал по заданию местной Академии наук статью о туркменском стихе, укороченный вариант которой использовал в предисловии к «Избранным стихам» Махтумкули [Переяслов, 2018]. 
В той мере, в какой позднейшие исследователи вправе восстанавливать душевное состояние поэта по его стихам, мы можем говорить о том, что через считаные недели после приезда Георгия Шенгели в Ашхабад от владевшего им чувства уныния и безысходности, отразившегося в «Старом докторе», не осталось и следа.

\section{Библиографический список / References}

Переяслов, 2018 - Переяслов Н.В. Маяковский и Шенгели: схватка длиною в жизнь. M., 2018. [Pereyaslov N.V. Mayakovskii and Shengeli: skhvatka dlinoyu v zhizn' [Mayakovskii and Shengeli: A life-long battle]. Moscow, 2018.]

Шенгели, 2017 - Шенгели Г.А. Стихотворения и поэмы: в 2 т. / Сост., подгот. текста, комм. В.А. Резвого, биограф. очерк В.Э. Молодякова. М., 2017. [Shengeli G.A. Stikhotvoreniya i poemy [Rhymes and poems]. In 2 volumes. V.A. Rezvyi (ed. and comm.), V.E. Molodyakova (bio sketch). Moscow, 2017.]

Статья поступила в редакцию 3.08 .2018

The article was received on 3.08 .2018

Иткин Илья Борисович - кандидат филологических наук; старший научный сотрудник отдела языков народов Азии и Африки, Институт востоковедения PAН; доцент факультета гуманитарных наук Школы лингвистики, Национальный исследовательский университет «Высшая школа экономики», г. Москва

Itkin Ilya B. - PhD in Philology; senior researcher at the Department of Asian and African Languages, Institute of Oriental Studies, RAS; associate professor at the Faculty of Humanities of the School of Linguistics, National Research University "Higher School of Economics", Moscow

E-mail: ilya.borisovich.itkin@gmail.com 


\section{Е.В. Николаева}

Московский педагогический государственный университет, 119991 г. Москва, Российская Федерация

\section{Переписка Л.Н. Толстого и Н.Н. Страхова'}

В статье рассматривается переписка Л.Н. Толстого с одним из немногих постоянных его корреспондентов - известным литературным критиком, философом и публицистом Н.Н. Страховым. Переписка, длившаяся четверть века, бросает новый свет на многие стороны интеллектуальной и творческой деятельности Толстого. В настоящей статье она рассматривается как своего рода интеллектуальный эпистолярный роман.

Ключевые слова: Л.Н. Толстой, Н.Н. Страхов, Ф.М. Достоевский, эпистолярное наследие.

\section{E.V. Nikolaeva}

Moscow Pedagogical State University, Moscow, 119991, Russian Federation

\section{Correspondence of L.N. Tolstoy and N.N. Strakhov²}

In contrast to Tolstoy's fiction, his epistolary has not been studied enough. This article deals with Lev Tolstoy's correspondence with one of his permanent correspondents - a notable literary critic, philosopher and journalist Nikolai Strakhov. An exchange of letters between them, which lasted a quarter of a century, throws new light on many aspects of Tolstoy's intellectual and creative activity.

\footnotetext{
${ }^{1}$ Статья подготовлена при поддержке РГНФ (грант № 11-04-00191а).

2 The study has been supported by the Russian Foundation for the Humanities, grant 11-04-00191a.
} 
In this article, their correspondence is considered as an intellectual epistolary novel sui generis.

Key words: Lev Tolstoy, Nikolai Strakhov, Fedor Dostoevsky, epistolary writing

13 февраля 1906 г. Л.Н. Толстой в письме к Петру Алексеевичу Сергеенко, собиравшему письма писателя для издания, сообщил: «Недавно думал про вас и, желая помочь вашему делу, вспомнил о том, что у меня было два (кроме А.А. Толстой, это третье) лица, к которым я много писал писем, и, сколько я вспоминаю, интересных для тех, кому может быть интересна моя личность. Это: Страхов и кн. Сергей Семенович Урусов. Может быть, вы бы могли найти эти письма для своей работы» [Толстой, т. 76, с. 98].

Николая Николаевича Страхова Толстой особо выделяет среди своих корреспондентов спустя годы после окончания их эпистолярного диалога, который длился около четверти века. Неслучайно среди томов переписки, изданных усилиями Общества Толстовского Музея и вышедших вскоре после смерти писателя, один том был отдан неполно опубликованной переписке с Александрой Андреевной Толстой [Толстовский Музей, 1911], а другой был посвящен также далеко не полному изданию переписки с Н.Н. Страховым [Толстовский Музей, 1914].

Фигура Николая Николаевича Страхова, обладавшего разносторонними знаниями, выступавшего в печати и как литературный критик, и как публицист, и как философ, нуждается на современном этапе изучения литературы XIX в. в серьезнейшем внимании исследователей. Его литературно-критическое, публицистическое, философское и эпистолярное наследие требует глубокого монографического изучения не только в силу его знакомства, сотрудничества, творческих связей и переписки с выдающимися современниками, среди которых Л.Н. Толстой, Ф.М. Достоевский, И.С. Аксаков, Н.Я. Данилевский и другие. Н.Н. Страхов является достаточно значительным и крупным деятелем своего времени, интеллектуалом и достойным сотоварищем и сотрудником своих более знаменитых современников, но при этом он оказался в их тени.

Убедительным примером, отражающим такое положение вещей, является давняя значительная и не утратившая своего интереса работа Б.И. Бурсова «Личность Достоевского» [Бурсов, 1974]. Жанр своего труда автор определил как роман-исследование и построил его с опорой не только на биографические данные и творчество великого писателя, но и на широкий историко-литературный контекст. Показательно, что один из героев этого романа-исследования - Н.Н. Страхов - является по сути дела персонажем, лишь иллюстрирующим и раскрывающим 
этот историко-литературный контекст. Наступило время пересмотра, переосмысления и собирания существующих сведений, знаний и представлений об этой яркой личности. Изучение наследия Н.Н. Страхова, как широко востребованного (его литературно-критические работы), так и полузабытого, а также эпистолярного наследия, как представляется, может дать наиболее объективные результаты именно в историко-культурном контексте эпохи.

Постепенно появляются публикации, так или иначе связанные с личностью и творчеством Н.Н. Страхова. Значительный вклад в разработку этой актуальной научной проблемы внесен Группой славянских исследований при университете Оттавы (Канада) в сотрудничестве с Государственным музеем Л.Н. Толстого в Москве, являющимся обладателем и хранителем рукописного наследия писателя, а также с Институтом мировой литературы им. А.М. Горького Российской академии наук. Ими подготовлен ряд изданий, среди которых «Л.Н. Толстой и С.А. Толстая. Переписка с Н.Н. Страховым» [Толстая, 2000], «И.С. Аксаков и Н.Н. Страхов. Переписка» [Аксаков, 2007], «Л.Н. Толстой и Н.Н. Страхов. Эпистолярный диалог о жизни и литературе» [Донсков, 2008] и, главное, двухтомное издание «Л.Н. Толстой и Н.Н. Страхов. Полное собрание переписки» [Переписка, 2003].

Переписка Л.Н. Толстого и Н.Н. Страхова занимает значительное место в эпистолярном наследии обоих корреспондентов. Толстой оставил нам несколько весьма значительных по объему эпистолярных диалогов. Прежде всего, это переписки с тремя женщинами, оказавшими на него значительное влияние и занимавшими важное место в его жизни. Хронологически первым сложился диалог в письмах с одной из его воспитательниц и дальней родственницей Татьяной Александровной Ергольской, у которой писатель во многом и учился премудростям эпистолярного этикета. Затем завязался диалог в письмах с другом, также родственницей и поистине неординарной личностью своего времени Александрой Андреевной Толстой, с которой писатель делился многими дорогими для него мыслями и творческими замыслами. Третьей по времени возникновения стала переписка с женой, Софьей Андреевной Толстой. Эпистолярному наследию Л.Н. Толстого исследователи, к сожалению, уделяли очень мало внимания, хотя наблюдения не только над содержанием, но и над формой его эпистолярия могут дать неоценимый материал для изучения русской эпистолярной культуры ХІХ в. в целом.

Ко времени начала переписки со Страховым Толстой совершенно свободно обращался к эпистолярной форме и в зависимости от необходимости не только на русском языке. От прежней неуверенности 
и боязни неверно выразить свои мысли и чувства на бумаге не осталось и следа.

Обстоятельства жизни и творческой работы Толстого складывались таким образом, что он, постоянно живя в Ясной Поляне, находился в кругу своих родных. Это, безусловно, не могло не ощущаться яркой творческой личностью как дефицит углубленного интеллектуального общения. Об этом свидетельствуют некоторые признания писателя, часто оброненные им вскользь, но вполне осознанные.

До начала переписки и знакомства со Страховым Толстой многие из волновавших его мыслей и суждений о литературе доверял А.А. Фету. Довольно частое личное общение с Фетом - значительная страница в биографиях писателей, а их переписка - одна из важнейших в эпистолярном наследии обоих. В 1866 г., в разгар работы над «Войной и миром», Толстой благодарит Фета в письме от 7 ноября за высказанные им замечания по первой части романа-эпопеи, в частности, по поводу образа князя Андрея, объясняет исторический характер реализуемого им творческого замысла и тут же признается: «Пожалуйста, пишите мне, милый друг, все, что вы думаете обо мне, т.е. моем писании, - дурного. Мне всегда это в великую пользу, а кроме вас у меня никого нет» [Толстой, т. 61, с. 149].

Через несколько месяцев Толстой пишет, но не отправляет письмо Ю.Ф. Самарину. Учитывая напряженный характер работы писателя над романом, можно предположить особенно острый недостаток в собеседнике, равном в интеллектуальном отношении: «Юрий Федорович! Не знаю, как и отчего это сделалось, но вы мне так близки в мире нравственном - умственном, как ни один человек. Я с вами мало сблизился, мало говорил, но почему-то мне кажется, что вы тот самый человек, которого мне нужно (ежели я не ошибся, то я вам нужен), которого мне недостает - человек самобытно умный, любящий многое, но более всего - правду и ищущий ее. Я такой же человек» [Там же, с. 156-157].

Вполне возможно, что это письмо осталось неотправленным в силу того, что в нем слишком откровенно Толстой исповедует свое умственное и нравственное одиночество. Можно заметить, что состояние Толстого усугубилось по сравнению с тем же мотивом, что звучит в письме к Фету.

Несколько лет спустя, уже в письме к Страхову, Толстой расскажет о встрече на железной дороге с Ф.И. Тютчевым. В этом письме вновь прозвучит мысль о возможном интеллектуальном диалоге, но уже не будет выражено острого чувства одиночества.

На фоне остро осознанной Толстым потребности в интеллектуально равном собеседнике и друге появляется Н.Н. Страхов, знакомство 
с которым завязалось по переписке в 1870 г., а через год превратилось в регулярное личное общение и сотрудничество в нескольких творческих работах.

В воспоминаниях старших сыновей Толстого сохранились сведения об этом общении и характеристика личности Страхова, данная как бы глазами семьи Толстого, членами которой Страхов, безусловно, был уважаем. Довольно краткие, но ценные в контексте данной темы сведения содержат «Мои воспоминания» Ильи Львовича Толстого: «Все без исключения, и взрослые и дети, любили его, и я не могу себе представить случая, чтобы он был кому-нибудь неприятен. <..> Страхову принадлежат первые и лучшие критические работы по поводу “Войны и мира" и “Анны Карениной”.

Когда издавались “Азбука” и “Книги для чтения”, Страхов помогал отцу в их издании. Но не одна только критическая работа сблизила Страхова с отцом. <..> В Страхове он больше всего ценил глубокого и вдумчивого мыслителя. Даже в разговорах, когда, бывало, отец задавал ему какой-нибудь научный вопрос (Страхов был по образованию естественник), я помню, с какой необыкновенной точностью и ясностью он излагал свой ответ. Как урок хорошего учителя < ..> Страхов был “настоящим другом” моего отца (как он назвал его сам), и я о нем вспоминаю с глубоким уважением и любовью» [Толстой, 1987, с. 142-144].

Глубоким уважением и дружеской привязанностью пользовался Страхов и со стороны Софьи Андреевны Толстой, которая так же, как и ее муж, состояла в переписке с ним.

Старший сын писателя, Сергей Львович Толстой, посвятил другу и корреспонденту отца специальный очерк «Николай Николаевич Страхов», который предназначался для его книги воспоминаний «Очерки былого». Там он вспоминает о первом появлении Страхова в Ясной Поляне, о его пребывании в самарском имении Толстых, о своих посещениях критика в Петербурге. Сергей Львович вспоминает и о последних годах общения писателя со своим другом и постоянным корреспондентом: «Взаимные отношения моего отца с Страховым остались дружественными до его смерти, несмотря на перелом в мировоззрении отца. В письме 18 ноября 1891 г. отец ему написал в ответ на жалобы Страхова на его одинокую жизнь: "Прощайте, милый друг; от души любя, целую вас. Не считайте себя одиноким. Вас любят, и я первый”.

Однако между ними уже не было прежнего единомыслия. После одного разговора отец так выразился о нем: “Страхов как трухлявое дерево, ткнешь палкой, думаешь, будет упорка, ан нет - она насквозь проходит, куда ни ткни, - точно в нем нет середины, - вся съедена наукой и философией”. Разумеется, это было сказано в дурную минуту, но из этих слов 
видно, как различны были их характеры: Л.Н. Толстой, ищущий правду в жизни, а не в книгах, деятельный и убежденный, и Н.Н. Страхов, не деятель, а зритель в жизни, не уверенный в себе, составивший свои убеждения преимущественно из книг» [Толстой, 1984, с. 128-135].

Сергей Львович Толстой, общавшийся со Страховым не только летом в Ясной Поляне, но и в привычной для критика петербургской среде, отмечает многие черты характера, особенности суждений, жизненные привычки и вкусы, обнаруживающие в нем человека очень рационального, поглощенного своими занятиями, умеющего хорошо организовывать свой труд, но отличающегося подчас достаточно странными вкусами и суждениями.

В эпистолярном диалоге со Страховым Толстой получил, наконец, возможность общения с интеллектуально соответствующим ему и высокообразованным собеседником. Их переписку можно рассматривать как подлинно интеллектуальный роман в письмах. На протяжении двух с половиной десятилетий в этом романе сложилось множество сюжетных линий, которые были в равной степени интересны обоим корреспондентам.

Еще до начала переписки в семье Толстых были известны критические статьи Страхова о «Войне и мире». Вероятно, критик верно понял и оценил многое в книге Толстого, что расположило к нему автора и послужило одной из побудительных причин начала переписки, а затем и личного знакомства. Уже в первом неотправленном письме к Страхову Толстой касается одной из важнейших в ту пору для него тем, чувствуя своего рода созвучие настроений и мысли. Все дальнейшее содержание их интеллектуального эпистолярного диалога во многом будет определено теми «узлами», которые завязались в этой переписке еще в 1870 -е гг.

Непростые 1870-е гг. были отмечены в жизни Толстого творческим, мировоззренческим и религиозным кризисами, работой над «Азбукой» и «Новой азбукой», в которой Н.Н. Страхов принимал самое деятельное участие, несколькими неосуществленными, но важными для писателя замыслами, а также вызреванием и формированием будущего романа «Анна Каренина». В первом письме Л.Н. Толстого к Н.Н. Страхову от 19 марта 1870 г. из Ясной Поляны речь идет о статье Страхова «Женский вопрос», написанной им по поводу книги Джона Стюарта Милля «Подчиненность женщины» [Страхов, 1870]. Статья впоследствии вошла в книгу Страхова «Борьба с Западом в нашей литературе». Толстой пишет, что с большим удовольствием прочел статью и под всеми выводами полностью подписывается. В этом же письме он высказывает две важных для себя и взаимосвязанных мысли. Первая из них - та, 
что «род человеческий развивается только в семье», где для каждой женщины является необозримое поле деятельности, даже если эта женщина сама одинока и лишь помощница в чужой семье. Вторая также остро волновала Толстого в связи с контекстом книги Милля по поводу существования и роли в обществе «магдалин». В связи с обсуждением этого вопроса Толстой высказывается по поводу семейных отношений: «Допустить свободную перемену жен и мужей (как этого хотят пустобрехи либералы) - это тоже не входило в цели Провидения по причинам ясным для нас - это разрушало семью» [Переписка, 2003, с. 1-2]. К этому следует добавить, что еще в декабре 1868 г. Толстой написал «Заметку о браке и призвании женщины», где также были высказаны мысли писателя о значении брака и воспитания детей.

В начале 1873 г. Л.Н. Толстой написал А.А. Толстой письмо, в котором объединены его суждения о «Войне и мире» и «Азбуке». В ответ на ее сообщение о чтении «Войны и мира» Толстой пишет: «...мне Война и мир теперь отвратительна вся. Мне на днях пришлось заглянуть в нее для решения вопроса о том, исправить ли для нового издания, и не могу вам выразить чувство раскаянья, стыда, которое я испытал, переглядывая многие места! Чувство вроде того, которое испытывает человек, видя следы оргии, в которой он участвовал. - Одно утешает меня, что я увлекался этой оргией от всей души, думал, что кроме этого нет ничего.

Азбуку мою, пожалуй, не смотрите. Вы не учили маленьких детей, вы далеко стоите от народа и ничего не увидите в ней. Я же положил на нее труда и любви больше, чем на все, что я делал, и знаю, что это одно дело моей жизни важное. Ее оценят лет через 10 те дети, которые по ней выучатся» [Толстой, т. 62, с. 8-9].

Признавая «Азбуку» единственно важным делом своей жизни, писатель, в сущности, выявляет ее узловое значение по отношению ко всему периоду творческой жизни конца 1860-х - 1870-х гг. Неудовлетворенность «Войной и миром» - лишь одна из нитей, сплетающихся в этот узел. Эта неудовлетворенность приведет Толстого к поискам и творческому кризису, выход из которого будет найден во многом благодаря работе над «Азбукой» и языком детских рассказов, недаром он отмечал: «Если будет какое-нибудь достоинство в статьях азбуки, то оно будет заключаться в простоте и ясности рисунка и штриха, т.е. языка» [Там же, т. 61, с. 274].

Более всего содержание и результаты творческого кризиса Толстого отразились в переписке с Н.Н. Страховым. В этих письмах замечания о текущих делах по подготовке «Азбуки» перемежаются с суждениями писателя о состоянии современной литературы и оценкой своей 
работы. 3 марта 1872 г. Толстой пишет знаменитое и часто цитируемое письмо, из которого здесь приведена оценка языка «Азбуки» и которое продолжено размышлениями о связи творчества с народной основой: «Заметили ли вы в наше время в мире русской поэзии связь между двумя явлениями, находящимися между собой в обратном отношении: упадок поэтического творчества всякого рода - музыки, живописи, поэзии, и стремление к изучению русской народной поэзии всякого рода музыки, живописи /и украшения, / и поэзии. Мне кажется, что это даже не упадок, а смерть с залогом возрождения в народности. Последняя волна поэтическая - парабола была при Пушкине на высшей точке, потом Лермонтов, Гоголь, мы грешные, и ушла под землю. Другая линия пошла в изучение народа и выплывет, Бог даст, а Пушкинский период умер совсем, сошел на нет. $-<\ldots>$

Вы поймете, вероятно, что я хочу сказать. -

Счастливы те, кто будут участвовать в выплывании. Я надеюсь» [Толстой, т. 61, с. 274-275].

Именно со Страховым писатель откровенно делится своими размышлениями, надеясь на полное взаимопонимание. В ответном письме Страхов дважды заговаривает о своем «предчувствии», «что дело идет о слиянии с народною поэзиею», но оставляет эту тему, описывая непосредственные обстоятельства своей совместной работы с Толстым [Переписка, 2003, с. 22]. Толстой же в следующем письме от 22-25 марта 1872 г. разъясняет свои позиции: «Правда, что ни одному французу, немцу, англичанину не придет в голову, если он не сумашедший (написание Толстого. - E.H.), остановиться на моем месте и задуматься о том - не ложные ли приемы, не ложный ли язык тот, которым мы пишем и я писал; а русский, если он не безумный, должен задуматься и спросить себя: продолжать ли писать, поскорее свои драгоценные мысли стенографировать, или вспомнить, что и Бедная Лиза читалась с увлечением кем-то и хвалилась, и поискать других приемов и языка. И не потому, что так рассудил, а потому что противен этот наш теперешний язык и приемы, а к другому языку и приемам (он же и случился народный) влекут мечты невольные» [Толстой, т. 61, с. 277]. «Бедная Лиза» Карамзина, по словам Толстого, «выжимала слезы, и ее хвалили, а ведь никто никогда уже не прочтет, а песни, сказки, былины - все простое будут читать, пока будет русский язык» [Там же, с. 278].

Подбирая материал для «Азбуки», писатель много внимания уделял устному народному творчеству, памятникам древнерусской литературы, что укрепляло его в поисках того языка, «которым говорит народ и в котором есть звуки для выражения всего, что только может желать сказать поэт... Язык этот, кроме того - и это главное - есть лучший 
поэтический регулятор» [Толстой, т. 61, с. 278]. Отстаивая направление своих поисков, писатель отрицает не только «Войну и мир», «Бедную Лизу», но пишет, что он «изменил приемы своего писания и язык, но, повторяю, не потому, что рассудил, что так надобно. А потому, что даже Пушкин мне смешон, не говоря уж о наших элукубрациях, а язык, которым говорит народ и в котором есть звуки для выражения всего, что только может желать сказать поэт, - мне мил. Язык этот, кроме того и это главное - есть лучший поэтический регулятор. Захоти сказать лишнее, напыщенное, болезненное - язык не позволит, а наш литературный язык без костей; так набалован, что хочешь мели - все похоже на литературу [Там же, с. 277-278].

В процитированных корреспонденциях Толстого особое внимание обращено на устное народное творчество, в том числе на былины, в которых в то время он черпал творческое вдохновение не только в связи с работой над «Азбукой», но и в связи с замыслом создания романа о русских богатырях. Совместная со Страховым работа над «Азбукой» - отдельная и специальная тема исследования.

Обдумывая после окончания «Войны и мира» темы возможных будущих творческих работ, которые способны были бы по-настоящему увлечь, Толстой обращается к героям и материалу былин. В отличие от намерения написать роман о декабристах или об эпохе Петра, от этого замысла не осталось ни множества вариантов начала, ни сколько-нибудь проработанного материала в записных книжках, ни ясных записей в дневнике, позволяющих судить об основной идее произведения или о его основных сюжетных линиях. Следом толстовского замысла остался лишь своеобразный план, в котором для памяти писатель отмечает одним-двумя словами не сюжетную линию, а лишь намек на нее, отсылающий к текстам былин или собственным добавлениям. Весь план разбит на части, озаглавленные именами былинных богатырей. Этот план при публикации в Юбилейном собрании сочинений писателя получил условное название «Заметки к роману о русских богатырях» [Там же, т. 90, с. 109-110].

Герои предполагаемого романа представлялись Толстому людьми современными, но носителями характеров былинных богатырей. И только тогда, когда явственным для писателя стал образ героини будущего романа, все мужские типы, ранее представлявшиеся Толстому в связи с неосуществленным замыслом, легко сгруппировались вокруг нее. Так же, как в роман вошла тема положения женщины в обществе, семейных отношений. Все это органически преобразуется в содержании и проблематике романа «Анна Каренина».

Характер переписки Л.Н. Толстого и Н.Н. Страхова на рубеже 1870-1880-х гг. свидетельствует о доверительности и искренности 
отношений и, следовательно, общего тона писем обоих корреспондентов. Пережив творческий, мировоззренческий, возрастной и религиозный кризисы на протяжении 1870-х гг., Толстой готовился, если можно так определить, к новому вступлению в литературу, с новых мировоззренческих и религиозных позиций.

На лето 1879 г. Толстой задумывал две поездки: в Соловецкий монастырь и в Киев. В письме от 1-2 мая 1879 г. Толстой, извиняясь за возможную некорректность в предыдущем письме, в котором он «не звал» своего корреспондента на лето в Ясную Поляну, сообщает Страхову: «Подразумевал же я то, что в моей к вам дружбе вы не можете сомневаться, а что я, сбираясь работать летом, именно вас-то и боюсь. Боюсь, потому что работа моя состоит в том, чтобы высказать свои мысли, заставив их полюбить, всем; когда же я с вами, я знаю, что вы любите мои мысли и высказывать мне их легко кое-как, намеком, и я порчу свою работу. А удержаться не могу, потому что мне ваше сочувствие очень дорого» [Переписка, 2003, с. 514]. Думается, что это письмо во многих отношениях может быть оценено как этапное. Начиная с этого письма, Толстой будет по-прежнему много писать Страхову по поводу своей творческой работы, в том числе о религиозных и философских сочинениях, над которыми он работал в 1880-е гг. Однако писатель скупее будет в выражении своих мыслей и чувств. Вероятно, он особенно дорожил мыслями, перекликающимися с заключенными в его религиознофилософских сочинениях.

Совершенно иную картину представляют собой письма Страхова с точки зрения выраженных в них чувств, мыслей и настроений самого задушевного толка. Страхов продолжает делиться со своим корреспондентом в том числе и размышлениями о духовной стороне своей жизни. В конце декабря того же 1879 г. Страхов гостит в Ясной Поляне, а уже в первом в 1880 г. письме (от 8 января) он фактически исповедуется Толстому, видимо продолжая личные беседы, состоявшиеся при встрече и разделяя высказанные в этих беседах мысли писателя: «Скажу Вам откровенно, что меня прежде смущало и отчего для меня так нова Ваша теперешняя мысль. Мне всегда казалось непонятным и диким личное бессмертие в той форме, в которой его обыкновенно представляют; точно также мне был всегда противен мистический восторг, до которого старались доходить большинство религиозных людей, говоривших почти так, как Вы. Но Вы избежали и того, и другого; как ни горячи движения Вашей души, но Вы ищете спасения не в самозабвении и замирании, а в ясном и живом сознании» [Там же, с. 552]. В тоне и содержании этого письма видны и преклонение Страхова перед личностью Толстого, и полная доверительность их общения. 
В письме упомянуты слишком важные для религиозного человека темы разговоров: о бессмертии души и о мистическом восторге религиозных людей. Для Толстого вопрос о бессмертии души стоял как актуальный еще во время смерти старшего брата Николая. В дневнике и письмах 1860 г. и ближайших лет сначала ставится вопрос о Боге и о невозможности принять мысль о том, что после смерти ничего не остается от Николая. Для Страхова «спастись» было совершенно конкретным понятием: в контексте этого письма он намеревается «спастись» на пути, предлагаемом Толстым.

С уверенностью можно утверждать, что эпистолярный роман «Толстой - Страхов» из романа интеллектуального в начале 1880-х г2. преврашается также и в психологический. Однако психологическая составляющая содержания этого романа представляется своеобразной и достаточно односторонней: как уже было сказано, наиболее открытым в высказывании своих мыслей и выражении своих настроений остается Страхов, хотя Толстой продолжает делиться со своим другом и корреспондентом дорогими ему мыслями.

Исповедальное содержание в письмах обоих корреспондентов - одна из сюжетных линий этого интеллектуально-психологического романа в письмах.

Вторая сюжетная линия эпистолярного романа - как всегда, как сложилось это с самого начала переписки, освещение творческой работы, текущих творческих планов, их постепенного осуществления, переживание и осмысление критических отзывов на эти работы.

Третьей сюжетной линией, отчетливо просматривающейся в переписке Страхова с Толстым, является постоянно присутствующее в их взаимоотношениях сотрудничество: от Толстого с завидной регулярностью и постоянством отсылаются письма с поручениями о приискании и присылке необходимых писателю для работ книг. Надо отметить, что Страхов практически всегда четко и быстро выполняет эти поручения, понимая степень важности творческой работы и интеллектуального поиска Толстого.

Другими сюжетными линиями романа являются также постоянно присутствующие темы: Н.Я. Данилевский, его личность и творческое наследие; В.С. Соловьёв и философские вопросы, обсуждаемые в переписке, что может и должно явиться темой самостоятельного и отдельного исследования.

Особые сюжетные линии этого интеллектуально-психологического романа - личность и произведения Ф.М. Достоевского и заметно изменяющиеся на протяжении 1880-х гг. отношения между Толстым и Страховым, отразившиеся в содержании и характере их писем. 
С конца 1880 г. становится заметной некоторая психологическая неуверенность Страхова, сказывающаяся в некоторых письмах и не всегда заметная при первом прочтении или теряющаяся среди вполне серьезных проблем, обсуждаемых в письмах.

Во второй половине 1880 г. Страхов начинает письмо так: «Ваше письмо, бесценный Лев Николаевич, сделало меня счастливым на несколько дней. По своему малодушию я все боялся, что уж наскучил Вам, или что Вы недовольны. Стасов прибежал с писком и радостью.

- Я получил письмо от Толстого!

«И я получил!»

- Ну, давайте мне свое, а я Вам дам свое.

И мы принялись читать. А до тех пор, бывало, каждый раз как встретимся, спрашиваем: Ничего нет? - Ничего? - и разойдемся.

И как Вы милы! О деньгах ничего не пишете, а написали то, что мне приятно и полезно.

И приятно и полезно мне напоминание об моей статье. Полезно и очень важно предостережение от суеты мыслли» [Переписка, 2003, с. 584].

В ответ - письмо-записка от Толстого в несколько строк и именно о деньгах. На этом этапе в переписке становится заметна некоторая перемена в тоне писем. Толстой постепенно, а во второй половине 1880-х гг. это становится особенно заметно, отвечает благосклонно и заинтересованно, но пишет много короче, чем раньше, значительно реже и, в основном, в письмах содержатся различного рода поручения к Страхову.

В письмах Страхова к Толстому также постепенно, но все чаще и настойчивее появляются упоминания о посещениях Кузминских. В тоне и самом факте постоянных упоминаний о ближайших родственниках писателя, возможно, для Страхова слышался некий «отзвук» жизни в Ясной Поляне.

Неоднократно письма к Страхову от Толстого представляли собой на самом деле письмо, написанное Софьей Андреевной, в котором сообщались необходимые сведения, а Толстой делал лишь небольшую приписку. Надо отметить, что Софья Андреевна всегда была неизменно внимательна и ласкова к Страхову, особенно ценя его помощь.

В начале июля 1885 г. Страхов пишет Толстому после подробного отчета по поручениям последнего: «Простите меня, дорогой Лев Николаевич! Мне чего-то недостает после нынешнего проживания в Ясной Поляне. Я очень радовался, видя, как живо идет Ваша деятельность; но не послало мне небо ни одного задушевного разговора, после которого прибывает у меня сил. Сам виноват; для таких минут нужно быть более добрым и менее тупым, чем я теперь. Итак, простите меня; не забывайте только неизменной любви Вашего Н. Страхова» [Там же, с. 686-687]. 
Незадолго до высказанного здесь Страховым сожаления в тоне писем Толстого чувствуется небольшое охлаждение к Страхову: он все более и более из корреспондента, с которым делятся самыми сокровенными мыслями, превращается в неизменно аккуратного и распорядительного исполнителя поручений писателя. Надо также заметить, что с 1883 г. в окружении Л.Н. Толстого появляется В.Г. Чертков, который вскоре займет самое близкое к писателю место.

Едва ли заметное самому Толстому охлаждение в отношении к своему корреспонденту, сказавшееся в тоне и содержании его писем, не остается незамеченным Страховым. Характер его приписок, отражающих развитие «психологического сюжета» этого романа в письмах, становится все более очевидным.

Одна из самых психологически напряженных сюжетных линий в переписке 1880-х гг. связана с Ф.М. Достоевским. Оставляя за пределами рассмотрения весь объем фактов, связанных с взаимным интересом Толстого и Достоевского друг к другу, укажем лишь на факт несостоявшегося знакомства писателей в 1878 г., в чем, как известно, решающую роль сыграл Страхов, знавший о их желании познакомиться и не представивший их друг другу. В это время Страхов не только сотрудник и корреспондент обоих писателей, но и человек, который с полным правом может называть себя другом Толстого, как тот сам его аттестует в письмах. Рискнем предположить, что, знакомя двух гениев, Н.Н. Страхов рисковал остаться «третьим лишним», человеком, всего лишь исполняющим поручения по подысканию нужной литературы, но никак не тем корреспондентом, с которым Толстой стал бы делиться слишком глубоко волнующими его мыслями.

В пределах 1880-х гг. сюжет «Толстой - Страхов - Достоевский» в рамках интеллектуально-психологического эпистолярного романа развивался следующим образом. Осенью 1880 г. Страхов дает прочитать Достоевскому письмо Толстого с отзывом о его произведении, в котором писатель сообщал: «На днях нездоровилось, и я читал Мертвый дом. Я много забыл, перечитал и не знаю лучше книги изо всей новой литературы, включая Пушкина» (письмо от 25-26 сентября) [Переписка, 2003, с. 578]. Учитывая образ мыслей и настроения Толстого начала 1880-х гг., можно понять, почему даже произведения Пушкина кажутся ему уступающими правде «Записок из Мертвого дома». Уже 2 ноября того же года Страхов рассказывает о реакции Достоевского на отзыв Толстого: «Видел я Достоевского и передал ему Вашу похвалу и любовь. Он очень был обрадован, и я должен был оставить ему листок из Вашего письма, заключающий такие дорогие слова. Немножко его задело Ваше непочтение к Пушкину, которое тут выражено (“лучше 
всей нашей литературы, включая Пушкина”). “Как, - включая?” спросил он. Я сказал, что Вы и прежде были, а теперь особенно стали большим вольнодумцем» [Переписка, 2003, с. 579].

В начале 1881 г. умирает Ф.М. Достоевский, о чем Страхов сообщает в письме к Толстому от 3 февраля (писатель скончался 28 января), передавая свое первое, непосредственное впечатление от его смерти: «Чувство ужасной пустоты, бесценный Лев Николаевич, не оставляет меня с той минуты, когда я узнал о смерти Достоевского. Как будто провалилось пол-Петербурга, или вымерло пол-литературы. Хоть мы не ладили все последнее время, но тут я почувствовал, какое значение он для меня имел: мне хотелось быть перед ним и умным, и хорошим, и то глубокое уважение, которое мы друг к другу чувствовали, несмотря на глупые размолвки, было для меня, как я вижу, бесконечно дорого. Ах, как грустно! Не хочется ничего делать, и могила, в которую придется лечь, кажется, вдруг близко подступила и ждет. Все суета, все суета!

В одно из последних свиданий я высказал ему, что очень удивляюсь и радуюсь его деятельности. В самом деле, он один равнялся (по влиянию на читателей) нескольким журналам. Он стоял особняком, среди литературы почти сплошь враждебной, и смело говорил о том, что давно было признано за соблазн и безумие. Зрелище было такое, что я изумлялся, несмотря на все свое охлаждение к литературе» [Там же, с. 591].

В этом непосредственном отклике кроме трудно переживаемого чувства внезапной потери близкого человека проскальзывают весьма важные в контексте избранной темы исследования детали: во-первых, это признание в том, что личность и деятельность Достоевского Страхова удивляла, во-вторых, он открыто признается в том, что ему всегда хотелось казаться в глазах Достоевского умным и хорошим. Как окажется немного позднее, Страхов, близко знавший Достоевского и сотрудничавший с ним, вряд ли из-за близости расстояния вполне отдавал себе отчет в гениальности последнего. В человеке неординарном, довольно тяжелом и непредсказуемом в ежедневном бытовом поведении, Страхову, вероятно, трудно было увидеть и признать безусловно гениальное явление. В продолжении своего письма он рассказывает Толстому о похоронах писателя и реакции почитателей его таланта, которые не проявили никакой фальши («почти ничего не было напускного, заказного, формального») [Там же]. В конце этого же письма, как бы в подтверждение высказанной здесь мысли, он сообщает о трудной для него необходимости выступить по поводу смерти Достоевского в Славянском комитете, просит позволения сослаться на упомянутое письмо Толстого и признается, что перечитывает «Записки из Мертвого дома», в которых теперь его удивляют простота и искренность, не оцененные 
им прежде. Это грустное письмо заканчивается болезненно-душевным восклицанием: «Простите, дорогой Лев Николаевич; не забывайте, не покидайте меня» [Переписка, 2003, с. 592].

Ответ Толстого, написанный практически сразу по получении письма Страхова (3 февраля Страхов датирует свое письмо из Петербурга, a 5-7 февраля датировано письмо Толстого), так же непосредственно в выражении чувства и в оценке Достоевского: «Получил сейчас ваше письмо, дорогой Николай Николаевич, и спешу вам ответить.

Разумеется, ссылайтесь на мое письмо.

Как бы я желал уметь сказать все, что я чувствую о Достоевском. Вы, описывая свое чувство, выразили часть моего. Я никогда не видал этого человека и никогда не имел прямых отношений с ним, и вдруг, когда он умер, я понял, что он был самый, самый близкий, дорогой, нужный мне человек. Я был литератор и литераторы все тщеславны завистливы, я, по крайней мере, такой литератор. И никогда мне в голову не приходило меряться с ним - никогда. Все, что он делал (хорошее, настоящее, что он делал), было такое, что чем больше он сделает, тем мне лучше. Искусство вызывает во мне зависть, ум тоже, но дело сердца только радость. - Я его так и считал своим другом, и иначе не думал, как то, что мы увидимся и что теперь только не пришлось, но что это мое. И вдруг за обедом - я один обедал, опоздал - читаю умер. Опора какая-то отскочила от меня. Я растерялся, а потом стало ясно, как он мне был дорог, и я плакал и теперь плачу.

На днях, до его смерти, я прочел Униженные и оскорбленные и умилялся» [Там же, с. 593].

Страхов, судя по этому письму Толстого, очень чутко уловил невозможность для себя знакомства двух писателей, один из которых был для него «бесценный Лев Николаевич», а перед другим ему всегда хотелось выглядеть лучше.

После смерти Достоевского начинается работа Страхова над его биографией, об этой работе он впервые сообщает в июле 1881 г. На протяжении весны 1881 г. Достоевский так или иначе упоминается в переписке. Страхов начинает печатать в «Руси» «Письма о нигилизме», которые вызвали разнообразные отклики. В этой ситуации он остро чувствует нехватку Достоевского: «Как живо мне вспомнился при этом Достоевский! Он был мой усерднейший читатель, очень тонко все понимал и не прочитал только Писем о спиритизме, потому что был в этом вопросе так раздражен, что не в силах был читать» [Там же, с. 603].

Упоминания о работе над биографией Достоевского встречаются в письмах Страхова от 22 июля 1881 г., от 6 июля 1883 г. Эти два года резко изменили настроение Страхова по отношению к работе: 
«Я бы и сейчас перенесся к Вам, если бы послушался своего желания, но мне совестно бросить работу, которая идет плохо, но подвигается вперед порядочно» [Переписка, 2003, с. 644].

16 августа 1883 г. - новый поворот в отношении к работе и к самому Достоевскому: «Опять я оторвался от письма к Вам, но зато почти кончил свою “биографию”. Не ожидал я, что это так меня увлечет, и если первая половина будет скучна, то вторая, вероятно, прочтется с интересом. Какое странное явление этот человек! И отталкивающее, и привлекательное» [Там же, с. 647].

В сентябре от Страхова приходит сообщение, что началось печатание его воспоминаний о Достоевском, но работа еще продолжается, а уже в ноябре 1883 г. в переписке складывается поистине неординарная ситуация. 28 ноября Страхов отправляет Толстому большое письмо из Петербурга, которое называет «небольшим» и в котором сообщает о том, что у него для этого небольшого письма есть «богатейшая» тема: «Вы, верно, уже получили теперь Биографию Достоевского - прошу Вашего внимания и снисхождения - скажите, как Вы ее находите. И по этому случаю хочу исповедаться перед Вами. Все время писания я был в борьбе, я боролся с подымавшимся во мне отвращением, старался подавить в себе это дурное чувство. Пособите мне найти из него выход. Я не могу считать Достоевского ни хорошим, ни счастливым человеком (что, в сущности, совпадает). Он был зол, завистлив, развратен, и он всю жизнь провел в таких волнениях, которые делали его жалким, и делали бы смешным, если бы он не был при этом так зол и так умен. Сам же он, как Руссо, считал себя лучшим из людей, и самым счастливым» [Там же, с. 652]. Останавливая здесь цитирование письма, примем во внимание, что именно это письмо стало актом настоящего отречения Страхова от Достоевского, практически полного уничижения его личности, хотя и при оговорках в пользу ума.

Изменяя своему обыкновению писать небольшие письма Страхову, Толстой отвечает на это письмо довольно большим посланием практически так же быстро, как реагировал на известие о смерти Достоевского (письмо от 6 декабря из Москвы). Не укоряя Страхова, как будто не было в его письме резких слов о Достоевском, Толстой обнаруживает не только полное понимание личности своего современника (гораздо более глубокое, нежели Страхов, знавший его лично), но и подчеркивает свое внутреннее родство с ним: «Книгу Вашу прочел. Письмо ваше очень грустно подействовало на меня, разочаровало меня. Но вас я вполне понимаю и, к сожалению, почти верю вам. Мне кажется, вы были жертвой ложного, фальшивого отношения к Достоевскому - не вами, но всеми преувеличения его значения и преувеличения по шаблону, 
возведения в пророка, святого - человека, умершего в самом горячем процессе внутренней борьбы добра и зла. Он трогателен, интересен, но поставить на памятник в поучение потомству нельзя человека, который весь борьба. Из книги вашей я в первый раз узнал всю меру его ума. Чрезвычайно умен и настоящий» [Переписка, 2003, с. 655].

В письме от 12 декабря Страхов пытается смягчить впечатление от своей исповеди: «В своих Воспоминаниях я все налегал на литературную сторону дела, хотел написать страничку из Истории литературы; но не мог вполне победить своего равнодушия. Лично о Достоевском я старался только выставить его достоинства; но качеств, которых у него не было, я ему не приписывал. Мой рассказ о литературных делах, вероятно, мало Вас занял. Сказать ли, однако, прямо? И Ваше определение Достоевского, хотя многое мне прояснило, все-таки мягко для него. Как может совершиться в человеке переворот, когда ничто не может проникнуть в его душу дальше известной черты? Говорю - ничто - в точном смысле этого слова; так мне представляется эта душа. О, мы несчастные и жалкие создания! И одно спасение - отречься от своей души» [Там же, с. 660].

Думается, что Толстой смог тонко понять Достоевского. Вплоть до последнего дня своей жизни в Ясной Поляне он перечитывал его произведения, чувствуя не только созвучие своим мыслям, но и понимая, насколько Достоевский угадывал и прозревал душевные борения такого типа личности, как сам Толстой, недаром в свое время Достоевский увидел за образом Левина в «Анне Карениной» самого автора.

В письме Л.Н. Толстого к Н.Н. Страхову от 19 мая 1887 г. выражена подлинная суть и содержание этого эпистолярного романа за 1880-е гг.: «Ваши книги и мысли, выраженные в них, много мне помогли в уяснении тех вопросов, которыми я занят теперь. Надеюсь, что я их не извергаю сырыми, а ассимилировал, и что вы мне скажете: на здоровье.

Ваш друг Лев Толстой» [Там же, с. 740].

Можно с полной уверенностью утверждать, что в эти годы со стороны Толстого эпистолярный роман продолжает формироваться прежде всего как интеллектуальный, тогда как характер интеллектуально-психологического ему придает содержание писем Страхова, в том числе обсуждение личности и произведений Ф.М. Достоевского.

1890-е гг. были последними в истории эпистолярного общения Л.Н. Толстого и Н.Н. Страхова: переписка завершается в связи со смертью последнего. Открывается же она письмом Н.Н. Страхова от 24 апреля 1890 г. В этом письме - тянущаяся из прошлых лет щемящая нота уловленной Страховым отчужденности от Толстого: «Вы знаете, конечно, что ничье внимание, ничей отзыв мне так не дороги, как Ваши, 
хотя чувствую, что полной похвалы я уже не могу заслужить от Вас» [Переписка, 2003, с. 813].

В этом большом по объему письме подняты еще две очень важные в общении друзей темы: знакомство Страхова с А.А. Толстой и вставший при этом вопрос о вере: «Кстати - наконец я познакомился с Александрой Андреевной Толстою; она встретила меня у Кузминских, позвала к себе, и дважды я по часу и больше сидел у нее. Она все нападает на Вас, а я защищаю Вас. По случаю Афона она сказала: “ну, я прочла и вижу, что Вы верующий...”. Я стал отрекаться и указывал на то, что в моем рассказе этого нет. Она очень добра и очень чиста. Какая прямота и искренность! А все-таки нет у нее настоящего дела и она волнуется и хлопочет, чтобы наполнить жизнь» [Там же]. Тема веры, духовного состояния, ожидания приближающегося конца жизни изредка, но последовательно просматривается в письмах Н.Н. Страхова.

Вторая тема письма - творчество Толстого после перелома - одна из основных сюжетных линий этого эпистолярного романа. В данном случае это «Крейцерова соната», которую Страхов анализировал, как следует из письма, поэтапно, осваивая и оценивая достаточно корректно и содержание, и художественную манеру Толстого. «С Крейщеровою сонатою - в литературном отношении я совершенно помирился, видя, как действует Ваша повесть. Конечно, Вы знаете, что целую зиму только об ней и говорили и что вместо как Bamе здоровье? обыкновенно спрашивали: читали ли Bы Крейцерову сонату? Цензура очень Вам услужила, задержавши печатание, и Соната известна теперь и тем, кто не читал Ивана Ильича и Чем люди живь, - или читал, да ровно ничего не вынес. А Соната написана так, что всех задела. Самых бестолковых, которые приходили бы только в глупый сладкий восторг, если бы она была написана полною художественною манерою. Как естественно, что Вы торопились высказать нравоучение! Эта искренность и естественность подействовали сильнее всякого художества. Вы в своем роде единственный писатель: владеть художеством в такой превосходной степени и не довольствоваться им, а выходить прямо в прозу, в голое рассуждение - это только Вы умеете и можете. Читатель при этом чувствует, что Вы пишете от сердца, и впечатление выходит неотразимое» [Переписка, 2003, с. 814].

Тема творческой работы Толстого, художественной, продолжена в письме Страхова от 8 мая 1892 г. по поводу его печатной полемики с Владимиром Соловьёвым, в котором предметом обсуждения явилась и драма Толстого «Власть тьмы». В письме, объясняя свою позицию, Страхов дает оценку драме: «Когда я вздумал ссылаться на простой народ, то стал в уме перебирать Ваши сочинения и вспомнил Митрича. 
Перечитывая сцену, я не мог надивиться глубине ее смысла и с восторгом дочитал драму до конца. Ах, нужно бы об Вас писать, часто писать, и вот я не умею и не нахожу времени. Даст Бог, однако, что-нибудь да напишу.

Митрич не понравился Владимиру Соловьёву. В Русском Обозрении он напечатал против меня Отрицательный идеал нравственности, где много ехидства и очень мало толку» [Переписка, 2003, с. 903].

В оценках художественного творчества Страхов явно выделяет и подчеркивает в эти последние годы жизни его нравственное содержание. В этом аспекте важна оценка Страховым произведений Мопассана, некоторые из которых, как известно, Толстой высоко ценил, а обобщенный вывод Страхова был более суров: «Как Вы сказали, что не верите его описанию простонародья, так, я думаю, нельзя верить, что все отношения мужчин и женщин у французов сводятся к описаниям Мопассана. Он описывает сладострастие и распутство, и описывает превосходно, к несчастию; но любви у него нет. Простите меня, но читая много и подряд, я начинал чувствовать и скуку и отвращение» (Письмо от 14 октября 1894 г.) [Там же, с. 966].

В русле обсуждения вопросов художественного творчества очень важно выделить сделанное Толстым признание в своих сомнениях относительно способностей к «художественному». Это признание (в письме от 27-28 января 1895 г.) писатель сделал по поводу рассказа «Хозяин и работник»: «Если вы будете добры просмотреть еще разик и поправить, что там неладно, то я очень буду благодарен. Мне не нравится этот рассказ. И в вашем отзыве я слышу неодобрение. Пожалуйста, напишите порезче всё, что вы скажете об этом рассказе, говоря не со мною. Мне интересно знать: ослабела ли моя способность. Или нет. И если да, то это меня так же мало огорчит и удивит, как и то, что я не могу бегать так же, как 40 лет тому назад» [Там же, с. 978].

В ответном письме Страхов дает свой анализ рассказа, откровенно выделяя и то, что приводит его в восторг, и то, что представляется недочетами. Это письмо - образец поистине дружеского соучастия в творческой жизни своего корреспондента: «Пишу и думаю: верно я чего-нибудь не понял, не додумался. Тайна смерти - вот что у Вас бесподобно. До сих пор я, впрочем, не встречал читателей, которые умели бы это вполне ценить. Душевное смягчение и его смысл - только у Вас это можно найти. А сны! Удивительно! <...

“Ослабела ли Ваша способность?” Не ослабела, а в каждой строчке показывает полное мастерство. Странная мысль Вам пришла в голову! Верность и чистота каждой черты - изумительная!» [Там же, c. 979]. 
Представляется, что это письмо потому так живо по тону, что Толстой обращается со своими сомнениями к Страхову не только как к сотруднику, помогающему в работе, но как к давнему и задушевному другу.

В последний год жизни Страхов объехал дорогие для него места, повидал близких ему людей. Будучи в родном Белгороде, Страхов делает Толстому признание в письме от 22 августа 1895 г.: «Смерть уже подходит близко, и потому невольно я вглядываюсь в новую жизнь, которая пробивается со всех сторон» [Переписка, 2003, с. 1014].

В том же письме далее он переходит к роману «Воскресение». Восхищаясь героиней романа, живостью ее образа, сценой суда, Страхов не совсем удовлетворен образом Нехлюдова: «А всего менее ясно то, что всего труднее и всего важнее - Ваш герой. В нем ведь должно совершиться возрождение, и картина этого возрождения должна действовать всего сильнее. Предмет самый любопытный. В том или другом виде это будет история Черткова, и если бы уловили эту фигуру и ее внутреннюю жизнь - дело было бы удивительное. Но пока - лицо героя остается бледным и совершенно общим» [Там же].

Завершает эту тему письмо от 9 октября 1895 г.: «Но, не бросайте Воскресения! Напишите его так, чтобы это было действительно воскресение из мертвых. Как много я думал об этом удивительном перевороте, и с какой жадностью я стал бы читать эту книгу!

Мне думалось, что успех Хозяина и работника разогреет Вас на это писанье. Ведь читали все и скольким слова Ваши запали в душу!» [Переписка, 2003, с. 1021].

Кроме обсуждения художественного творчества Толстого, в переписке 1890-х гг. необходимо выделить две, как представляется, духовно и психологически важные для Страхова темы.

Первая поднята в сообщении о знакомстве Страхова с А.А. Толстой: вопрос о вере. Он продолжен письмом Страхова от 29 октября 1894 г., в котором он рассказывает своему другу о религиозных настроениях своего отрочества и юности. Страхов прямо признается в своей внутренней борьбе, сомнениях и колебаниях. Затем он продолжает неполным согласием с религиозной позицией Толстого, выделяя ее самую слабую сторону - «отречение от жизни; а от жизни люди отказаться не могут. Жизнь требует спокойных, твердых форм, требует простора для желаний, требует труда и отдыха, забавы и восторга... да вы все это отлично знаете. Все это сказано в Ваших сочинениях. Жизнь избегает усилий сознания и напряжения воли. Между тем Вы с Вашею вечно горящею душою предлагаете людям также вечно усиливаться и напрягаться. Они не могут делать того, что Вы делаете» [Там же, c. 969-970]. 
Вторая из этих тем - психологическое состояние Страхова ввиду приближающегося конца. Постепенно, но последовательно увеличивается в письмах доля исповедальных признаний и самооценок. Это письма от 24 августа 1892 г., 1/13 августа 1893 г., 3/15 августа 1893 г. и, наконец, от 2 мая 1895 г.: «Да, я свой грех знаю, и думаю о нем каждый день. Словами я выражаю это так: нужно обратиться к Богу. И вот, хочу исповедаться перед Вами: мне становится страшно от этой мысли; я чувствую себя таким ничтожным, слабым, порочным, я начинаю ставить для обращения к Богу такие высокие требования, желать в себе такой глубокой перемены, что теряю всякую решимость, не могу приступить к делу. Так со мною было всегда, всю жизнь. Я не женился и не собирался жениться только потому, что дело мне казалось сложным, трудным, ответственным. Я всегда очень боялся вмешательства в чужую жизнь со своей стороны, и старался не брать на себя никаких обязательств, пугаясь того, что не могу выполнить их как следует. Боже мой! Какая уродливость, какая безжизненность! Вероятно, отец родил меня в минуту несчастного раздумья. Все мне представляется в отвлеченном виде, и потому сложным и трудным; чувство никогда не бывает настолько живо, чтобы увлечь меня и порвать сеть мыслей. Я только избегаю дурного и только желаю хорошего, но делать хорошее не делаю по слабости стремления. Сознание этого мучит меня, и тогда я только говорю: прости меня, Боже, прости меня» [Переписка, 2003, с. 994].

Следует также отметить, что на протяжении последних лет переписки продолжается обсуждение не только творческой работы Толстого, но и трудов Страхова, потому в письмах появляются сведения о предпринимаемых работах, постоянно возникают имена Н.Я. Данилевского, Вл.С. Соловьёва, Ф.М. Достоевского, А.А. Фета, К. Леонтьева, В. Розанова. Анализ этих тем, «пронизывающих» переписку на протяжении многих лет, как было отмечено, является задачей особого и отдельного исследования.

24 января 1896 г. Н.Н. Страхова не стало - завершился один из самых насыщенных содержанием и мыслью интеллектуально-психологических эпистолярных романов в истории русской культуры. Н.Н. Страхова вспоминали все обитатели Ясной Поляны спустя годы после его смерти по самым разным поводам. Неоднократно имя Страхова всплывало в разговорах в связи с Достоевским. В семье Толстых не было забыто письмо Страхова, присланное писателю после смерти Достоевского и содержащее его осуждение. Спустя много лет, в июле 1908 г. Д.П. Маковицкий в своих ежедневных записях передает разговор, возникший в связи с появлением статьи о Достоевском: «Я рассказал Софье Андреевне про фельетон в "Руси" “Сплетня о Достоевском", где опровергается, что 
Достоевский будто бы был безнравственной жизни, как недавно вспоминала Софья Андреевна, опираясь на письмо Н.Н. Страхова.

Л.Н. не знал, что такие вещи говорились о Достоевском:

- Нехорошо было со стороны Страхова» [Маковицкий, 1979, с. 133].

Часто имя Страхова вспоминалось Толстым в связи с серьезнейшими для него вопросами, такими как смысл жизни и смерть: «Н.Н. Страхов не хотел думать о смерти, боялся ее.

Софья отозвалась с другого стола:

- И Тургенев такой был, боялся ее» [Там же, с. 227].

Знакомство и переписка с Н.Н. Страховым оставили глубочайший след в жизни Л.Н. Толстого. Не только в сознании писателя, но и всей его семьи и ближайшего окружения Страхов оставил по себе память как умный собеседник, тихий, любезный и доброжелательный человек, верный друг и помощник. Своего рода «суммарную» характеристику Страхову Толстой дал в разговоре с сыном Ильей. Илья Львович Толстой свидетельствует в своих воспоминаниях, что одно время его отца часто посещал Владимир Соловьёв. Эти посещения всегда заканчивались ожесточенными спорами. Заканчивались эти посещения всегда одинаково: «Когда гости разъезжаются, отец выходит их провожать в переднюю, и, прощаясь с Соловьевым, задерживает в своей руке его руку и, глядя ему в глаза с виноватой улыбкой, просит его не сердиться за его горячность.

И так всякий раз.

Соловьев, как мыслитель, никогда не был близок моему отцу, и очень скоро он перестал его интересовать совсем.

Отец считал его человеком “головным” и применял к нему эпитет "протоиереев сын”.

- Таких много, - говорил он. - "Протоиереев сын” - это человек, живущий исключительно тем, что ему дает книга. Начитается и делает из прочитанного выводы. А своего собственного, самого дорогого у него ничего нет. Есть и среди протоиереевых детей умные люди, как, например, Страхов, он был даже очень умен, и, если бы он думал от себя, он был бы велик, а вот в этом и было его несчастие, что он тоже был “протоиереев сын”.

Это определение я слышал от отца уже несколько лет после смерти обоих помянутых выше лиц» [Толстой, 1987, с. 193].

Л.Н. Толстой и Н.Н. Страхов вели свой эпистолярный диалог почти четверть века. Среди эпистолярного наследия писателя его переписка со Страховым одна из самых больших по объему и занимает одно из самых значительных мест, включая сведения о разных сторонах жизни писателя: личной и творческой. Исключительное значение и содержание этой переписки, как и факт ее возникновения, были 
обусловлены, в первую очередь, острой потребностью писателя в интеллектуально равном собеседнике и корреспонденте. Страхов полностью удовлетворял этому требованию, став также вскоре после знакомства верным помощником Толстого во многих творческих работах.

Письма обоих корреспондентов благодаря их содержанию составили подлинный эпистолярный роман. Эта переписка уже в 1870-е гг. превратилась в интеллектуальный эпистолярный роман, в котором за десятилетия сложилось много своего рода сюжетных линий. Одна из основных - сотрудничество Толстого и Страхова, всегда помогавшего писателю в его творческих работах. Эта же сюжетная линия включает в себя освещение творческой работы обоих корреспондентов.

В 1880-е гг. письма Страхова проникаются подлинной исповедальностью, что отражается и на характере этой переписки, приобретшей черты исповедально-психологического интеллектуального эпистолярного романа. Страхов часто сетует на редкие и небольшие, «формальные» корреспонденции Толстого. Возможно, это было связано с появлением в 1883 г. в окружении Толстого В.Г. Черткова, также ставшего близким другом писателя. Другие сюжетные линии этого эпистолярного романа связаны с иными постоянными темами переписки: личность и творчество современников, философские вопросы.

Наконец, особая сюжетная линия - личность и творчество Ф.М. Достоевского, переживание обоими корреспондентами его смерти, работа Страхова над биографией писателя.

\section{Библиографический список / References}

Аксаков, 2007 - И.С. Аксаков и Н.Н. Страхов. Переписка / Сост. М.И. Щербакова. Оттава, 2007. [I.S. Aksakov i N.N. Strahov. Perepiska [I.S. Aksakov and N.N. Strakhov. Correspondence]. M.I. Shcherbakova (ed.). Ottawa, 2007.]

Бурсов, 1974 - Бурсов Б.И. Личность Достоевского. Л., 1974. [Bursov B.I. Lichnost Dostoevskogo [Dostoevsky's personality]. Leningrad, 1974.]

Донсков, 2008 - Донсков А.А. Л.Н. Толстой и Н.Н. Страхов. Эпистолярный диалог о жизни и литературе. Оттава, 2008. [Donskov A.A. L.N. Tolstoy i N.N. Strahov. Epistolyarnyy dialog o zhizni i literature [Lev Tolstoy and Nikolai Strakhov. Epistolary dialogue about life and literature]. Ottawa, 2008.]

Маковицкий, 1979 - Маковицкий Д.П. У Толстого. 1904-1910. «Яснополянские записки». Книга третья. 1908-1909 (январь-июнь). М., 1979. [Makovickiy D.P. U Tolstogo. 1904-1910. «Yasnopolyanskie zapiski». Kniga tret'ya. 1908-1909 (yanvar'-iyun') [In Tolstoy. 1904-1910. "Yasnaya Polyana notes". Book three. 1908-1909 (January-June)]. Moscow, 1979.]

Переписка, 2003 - Л.Н. Толстой и Н.Н. Страхов. Полное собрание переписки / Сост. Л.Д. Громова и Т.Г. Никифорова, ред. А.А. Донсков. Оттава, 2003. [L.N. Tolstoy i N.N. Strahov. Polnoe sobranie perepiski [L.N. Tolstoy and 
N.N. Strakhov. Full collection of correspondence]. L.D. Gromova, T.G. Nikiforova (comp.), A.A. Donskov (ed.). Ottawa, 2003.]

Страхов, 1870 - Страхов Н.Н. Женский вопрос // Заря. 1870. № 2. С. 107-149. [Strakhov N.N. Women's issue. Zarya. № 2. Pp. 107-149.]

Толстая, 2000 - Л.Н. Толстой и С.А. Толстая. Переписка с Н.Н. Страховым / Сост. Л.Д. Громова и Т.Г. Никифорова, ред. А.А. Донсков. Оттава, 2000. [L.N. Tolstoy i S.A. Tolstaya. Perepiska s N.N. Strahovym [L.N. Tolstoy and S.A. Tolstaya. Correspondence with N.N. Strakhov]. L.D. Gromova, T.G. Nikiforova (comp.), A.A. Donskov (ed.). Ottawa, 2000.]

Толстовский Музей, 1911 - Переписка Л.Н. Толстого с гр. А.А. Толстой. 1857-1903 / Толстовский Музей. Т. І. СПб., 1911. [Perepiska L.N. Tolstogo s gr. A.A. Tolstoy. 1857-1903 [Correspondence L.N. Tolstoy with Countess A.A. Tolstaya. 1857-1903]. Tolstoy Museum (ed.). Vol. I. St. Petersburg, 1911.]

Толстовский Музей, 1914 - Переписка Л.Н. Толстого с Н.Н. Страховым. 1870-1894. С предисл. и прим. Б.Л. Модзалевского / Толстовский Музей. Т. ІІ. СПб., 1914. [Perepiska L.N. Tolstogo s N.N. Strahovym. 1870-1894. S predisl. i prim. B.L. Modzalevskogo [Correspondence L.N. Tolstoy with N.N. Strakhov. 1870-1894. Foreword and approx. B.L. Modzalevsky]. Tolstoy Museum (ed.). Vol. II. St. Petersburg, 1914.]

Толстой - Толстой Л.Н. Полное собрание сочинений: в 90 т. М.-Л., 1928-1958. [Tolstoy L.N. Polnoe sobranie sochineniy: v 90 t. [Complete Works: in 90 volumes]. Moscow-Leningrad, 1928-1958.]

Толстой, 1984 - Толстой С.Л. Николай Николаевич Страхов // Яснополянский сборник. 1982. Статьи. Материалы. Публикации. Тула, 1984. [Tolstoy S.L. Nikolai Strakhov. Yasnopolyanskiy sbornik. 1982. Stat'i. Materialy. Publikacii. Tula, 1984.]

Толстой, 1987 - Толстой И.Л. Мои воспоминания. M., 1987. [Tolstoy I.L. Moi vospominaniya [My memories]. Moscow, 1987.]

Статья поступила в редакцию 1.06.2018

The article was received on 1.06 .2018

Николаева Евгения Васильевна - доктор филологических наук, профессор; профессор кафедры русской литературы Института филологии, Московский педагогический государственный университет

Nikolaeva Evgenia V. - Dr. Phil. Hab.; Professor at the Department of Russian Literature of the Institute of Philology, Moscow Pedagogical State University

E-mail: nikolatva.ev.vas@yandex.ru 


\section{И.В. Софронова}

Чувашский государственный университет им. И.Н. Ульянова, 428015 г. Чебоксары, Российская Федерация

\section{Поэтические особенности четверостиший в литературе народов Поволжья}

Статья посвящена исследованию особенностей жанра рубаи в литературе народов Поволжья. Предметом анализа послужили стихотворения татарского поэта Р. Файзуллина и чувашского поэта В. Эндипа. Оба автора сочетают традиции восточной поэзии с особенностями национальной литературы и фольклора. Сходство между поэтиками этих авторов является следствием их увлечения традициями арабской и японской поэзии.

Ключевые слова: литература народов Поволжья, Р. Файзуллин, В. Эндип, рубаи, традиции японской поэзии.

\section{I.V. Sofronova}

I.N. Ulyanov Chuvash State University, Cheboksary, 428015, Russian Federation

\section{Poetic features of the quatrains in the literature of the peoples of the Volga region}

The article is devoted to the particulars of the poetic genre of ruba'i in literatures of the Volga region. The subject of an analysis are the poems of the Tatar poet R. Fayzullin, and the Chuvash poet V. Endip. Both authors combine the traditions of Eastern poetry and those of their national literatures and folklore. A similarity between the poetics of both authors is predetermined by their interest in the traditions of Arabic and Japanese poetry. 
Key words: literatures of the Volga region, R. Faizullin, V. Endip, ruba'i, traditions of Japanese poetry.

В литературах народов Поволжья в определенные периоды развития широкое распространение получил жанр восточной литературы рубаи, четверостишия философского характера. Он особенно характерен для чувашской, татарской, башкирской поэзии. На его распространение могло повлиять наличие подобного жанра в песенном фольклоре, а также влияние традиций восточной литературы.

Перевод стихотворений О. Хайяма способствовал зарождению интеpeca к данному жанру в чувашской поэзии 1930-х гг. Поэты И. Ивник, П. Хузангай знакомятся непосредственно с творчеством восточного автора, переводят его рубаи, пишут, подражая ему, оригинальные четверостишия.

Татарские поэты М. Гафури, Ш. Бабич, С. Кудаш, С. Бикбай в период поиска новых поэтических форм используют классический жанр, переделывают его на новый лад.

Обращение к жанру рубаи татарскими поэтами объясняется традициями фольклора и мусульманской литературы, на которых была основана татарская литература дооктябрьского периода.

В 1970-1990-х гг. наблюдается возрастание интереса поэтов Поволжья к четверостишиям. Рубаи чувашских поэтов Б. Борлена, М. Сениэля, П. Львова, А. Николаева-Кюльвара, А. Емельянова, А. Ыхра и других соответствуют по форме и содержанию традициям восточного жанра. «Авторы в четверостишиях выражают мировоззрение чувашского народа, затрагивают вечные проблемы бытия. В то же время стихотворения М. Карягиной, Ю. Семендера, Ф. Муратова, Н. Кушманова, А. Эсхеля, С. Азамат навеяны традициями чувашского песенного фольклора: частушек, банных такмаков, краткосюжетных песен» [Софронова, 2011, c. 194].

Распространение философского жанра в литературах тюркоязычных народов оказывает влияние на литературу финно-угров. Лаконичные по содержанию краткостишия марийского поэта В. Регеж-Горохова литературоведы называют рубаи. Увлечение поэта жанром восточной литературы отражает его поиски путей самовыражения, художественного идеала. В калмыцкой литературе рубаи характерен для творчества Д. Кугультинова.

Поэты начала XX в. старались строго придерживаться традиций рубаи, современные же авторы не слепо копируют восточных классиков, 
а привносят особенности народной поэтики, сочетают восточные традиции со своеобразием родной литературы. Трансформацию традиций рубаи наблюдаем в творчестве авторов Поволжья: чувашского В. Эндипа и татарского Р. Файзуллина.

В. Эндип в начале своего творчества тяготеет к эпическим формам. Он слагает поэмы, большие по объему стихотворения, через многословность выражает непростые взаимоотношения лирического героя с окружающим миром. Переход к краткости, философичности в творчестве В. Эндипа связан с увлечением восточной литературой, переводом восточной классики, возможно, присутствует и влияние возрастного фактора.

Р. Файзуллин является автором ряда поэм, циклов стихотворений. В конце 1980-х гг. поэт приходит к кратким формам. Обращение Р. Файзуллина к краткостишиям связано с литературным опытом, журналистской деятельностью. Если В. Эндип отдает предпочтение дву- и четверостишиям, то у Р. Файзуллина немало и трех-, и восьмистиший.

При проведении литературоведческого анализа рубаи у обоих поэтов обнаруживается некоторое сходство: четверостишие для них - это не всегда индоиранские рубаи с особым порядком рифмы, изложения смысла. Поэты используют традиционное количество строк, выражение философского смысла, минимализм в словах. Новшеством в их краткостишиях является сочетание традиций рубаи с особенностями японской поэзии. Это проявляется в использовании четверостишия, выражении в них философского смысла и изображении жизни природы. Стихотворения зачастую напоминают пейзажные зарисовки, моменты из повседневной жизни, они демонстрируют единство противоположных понятий и явлений. Вместе с особенностями японских краткостиший в их стихотворениях прослеживается и философия дзен-буддизма. Кроме того, поэты экспериментирует с порядком расположения строк.

Цикл стихотворений «Вутра с̧унман йӗркесем» ('Строки, не сгоревшие в огне') В. Эндипа напечатан в книге «Самана» ('Вехи века', 1987). В ней представлены четверостишия. Краткостишия Р. Файзуллина опубликованы в сборнике «Вечность мгновения» (2012).

Сходным для творчества обоих авторов является то, что в рубаи композиция служит для передачи философского смысла. Поэты затрагивают вечные проблемы бытия: жизнь и смерть, доброе имя, чистота и искренность желаний и т.д. 
Вёсусер пурнӑс̧ра пёртен пецр чӑнлӑх

Пурнӑс̧ хӑй пуль; вилецм ун мӗлки?

Вилёмрен вара с̧ынсем с̧ес̧ с̧ӑлес

Пурнӑс̧ра с̧апла тёнче йӗрки.

[Эндип, 1987, с. 179]

В бесконечности единственная истина -

Сама жизнь, смерть - это ее тень?

От смерти уберечь способны только люди.

В жизни таковы законы бытия 1 .

В стихотворении наряду с символами вечности (жизнь, смерть, вселенная), упоминается обычный смертный человек - противоположные понятия. Выражение От смерти уберечь способны только люди можно растолковать и как вовремя оказанная медицинская помощь, и как то, что доброе имя и дела твои будут жить в памяти тех, кто будет помнить тебя. Подобные четверостишия можно характеризовать как философские миниатюры. В них автор задумывается о бесконечности бытия, опредметчивает абстрактные понятия, говорит о них как о конкретных вещах.

Р. Файзуллин также через разговор о маленьких деталях, предметах передает размышление над глобальными проблемами.

Ике хәзинә дөньяда: саклагыз!

Каберстан аның берсе. Гел гәлдә булсын!

Китабханд - икенчесе. Куңелдә булсын!

Базар болай да калыр...

[Файзуллин, 2012, с. 21]

Два клада драгоиенных сохрани! -

Кладбище предков и собранье книг!

Живи, святье ченности любя!

Базар не пропадет и без тебя...

(Перевод В. Баширова)

В четверостишиях В. Эндип и Р. Файзуллин изображают рисунки природы, и как в японских танка или хокку, передают через них душевное состояние лирического героя:

Кӗрхи юмах тецччи-и ку е чӑн-и:

С̆̈̈хе кеиписене хыва-хыва, хуралнӑ хурӑнсем пус̧ хёрлӗ чӑмнӑ

текех никам пӑтратайми шыва.

[Эндип, 1987, с. 189]

1 Здесь и далее, кроме особо оговоренных случаев, перевод наш. - И.С. 
Это осенняя сказка или же реальность:

Сняв свои тонкие платья,

грязные березы окунулись

в воду, которую никто не замутит.

В стихотворении описывается осенний пруд. Перед глазами предстают березы, растущие вокруг пруда и их отражение в воде - реальность и ее зеркальное отражение. Березы, которые поэты чаще всего используют с эпитетами белье, чистыле, названы грязными. Строка в воду, которую никто не замутит показывает переход временных явлений жизни в разряд вечных. Осень, грязные березы в стихотворении символизируют трудные моменты в судьбе лирического героя. Около чистого, осеннего пруда он очищает душу, как грязные березы свою одежду, находит успокоение.

В четверостишиях, помимо простого рисунка природы, проявляется и философия дзен-буддизма - противопоставление красот и шумов мира тайнам тишины или же хаоса пустоте. Для объяснения своеобразия этих традиций А. Хузангай приводит размышление художника и поэта, дзенского монаха Хакуин Осё (1685-1786): «Мы знаем звук хлопка от двух ладоней, но как звучит хлопок одной ладони? Эта загадка-коан интерпретируется иногда в том смысле, что все слышимые и видимые в своем существовании равно непознаваемо, как и отсутствие, ничто» [Хузангай, 1987, с. 87].

У В. Эндипа сочетание березы окунулись является демонстрацией особенностей восточной философии. У Р. Файзуллина также наблюдаем противопоставление обыденной жизни пустоте:

Ага суда төз бер нарат

Салдан аерылганмы?

...Нарат ускән төптә ята

аккош каурыйлары

[Файзуллин, 2012, с. 19]

Молодую стройную сосну

По теченью пронесло бескрыло.

...На ее пеньке, в ее лесу

Два лебяжьх перышка застыло.

(Перевод М. Аввакумовой)

В стихотворении сочетания сосна - пронесло, пенек - два лебяжьих перышка противопоставлены друг другу. Наблюдается противопоставление наличия сосны и его отсутствия. Вместо него на пеньке остались 
только два лебяжьих перышка. Предметы легкие по сравнению с деревом. Так же с уходом человека остается лишь память о нем.

В четверостишиях смысл передается через контраст. У В. Эндипа они объединяют категории правды и лжи, доброго и нехорошего человека, мужчины и женщины, дружбы и вражды, жизни и смерти, добра и зла, человека и природы, молодости и старости, прошлого и будущего в одно единое. Р. Файзуллин рисует единство верхнего и нижнего пространства, многословности и безмолвия, родины и чужбины, признания и одиночества, света и тьмы, встречи и расставания. Нельзя утверждать, что они категорически контрастны между собой. Наоборот, они демонстрируют наличие гармонии явлений в природе, человеческой жизни. Противоположенные понятия в стихотворениях размещаются в двустишиях. В таких случаях поэты разделяют четверостишие на два двустишия. При этом каждое двустишие может содержать в себе частицу противоположного, создавая при этом рисунок, напоминающий единство инь и ян.

Әйттену: «Рәхмәт! Нинди хозур!

Нинди бахет бу яшау!».

Ә ник тамды балдагынца

Ике бөрдек куз яме?

[Файзуллин, 2012, с. 45]

- Чудесно! Все в жизни чудесно!

Я счастлива... - ты говорила.

Но видел я: ты на колечко

Две первых слезы уронила.

Первое двустишие выражает радость, второе - печаль. В понятие «печаль» вкраплено понятие «радость», оно передается через слово колечко. В данном случаи двустишия являются как бы зеркальным отражением друг друга.

Сёнксе лараттӑм эп шыл хёрринче.

Чӑрлаттаратчӗ шӑрчӑк - вӑл та тарчӗ.

Ү̈пре нӑйлатрӗ: ларчӗ - тӑрӑнтарче

Шӗп-шёвёр сӑннине... Вёрсе тартасче -

Пӗччен юлма хӑратӑп с̧ӗр с̧ине...

$$
\text { [Эндип, 1987, с. 150] }
$$

Сидел без дела я на берегу.

Скрипел кузнечик - перестал.

Комар пищуал, сел и воткнул

Свой хоботок... Эх, сдунуть бы его -

Боюсь один остаться на земле... 
Одинокому лирическому герою дороги и кузнечик, издающий пустые звуки, и кровопийца комар. Кузнечик и комар, маленькие детали на фоне природы, символизируют пустых и никчемных людей. Оказывается, мир без них тоже может опустеть, и такие люди нужны для вселенной. В. Эндип называет их айван (слабыми), ухмах (глупыми) людьми. В стихотворениях нередко образы свиньи, ворона олицетворяют таких людей. Рядом с ними всегда изображается или подразумевается добрый и бескорыстный человек.

Влияние традиций японской поэзии в творчестве обоих авторов проявляется в сочетании словесного рисунка с цветовой гаммой. Символическое значение цвета совпадает с народными представлениями. Чаще всего добрые светлые понятия ассоциируются с бельым, красным, синим цветами.

Курче, Кояш нурын ташыл,

Карльгач оя кора!

...Офыкта аны тузгытырга

зилзила болыт тора

[Файзуллин, 2012, с. 23]

Взгляни, вьет ласточка

Гнездо из солнечных лучей!

...И черной кошкой подползает

Губительная тучка к ней.

(Перевод А. Руденко)

Четверостишия поэтов отличает игра слов, использование их многозначности. Активно используются омонимы и омоформы:

Пуртан суук тунӑ чух чукмар

С̧укран пур тӑвакан суук мар.

[Эндип, 1987, с. 94]

Когда дубинка превращает то, что есть, в ничто,

Есть люди, которые из ничего

делают все.

Стихотворение строится на игре контрастных слов пур ('есть') и с̧ук ('нет’). Когда дубинка, т.е. время, превращает то, что есть, в ничто, находятся люди, которые готовы поживиться на этом, сделать себе выгоду. Также архаизмы и диалектизмы расширяют художественное пространство лирического произведения, привносят оттенок национального своеобразия. 
В русских переводах четверостиший Р. Файзуллина также наблюдаем использование однокоренных слов:

\section{Сарыкларны санаганда төгәл килеп чьгуччан. Халькларны санаганда хәлләп килеп чыгучан! \\ [Файзуллин, 2012, с. 25] \\ Поголовье сосчитают - \\ Точный сделают подсчет. \\ Поголовно сосчитают - \\ Обязательно просчет. \\ (Перевод В. Хамидуллиной)}

Однокоренные слова поголовье - поголовно, сосчитают - подсчет, сосчитают - просчет нужны для того, чтобы продемонстрировать, как одно понятие может легко перейти в противоположное.

В отличие от В. Эндипа, в творчестве Р. Файзуллина немало стихотворений, соответствующих по форме и содержанию традициям индоиранского рубаи. Поэт использует устоявшиеся мотивы вина, бренности человеческого бытия, восхваления любви. В четверостишиях он не призывает любить, а рассказывает о своем чистом и большом чувстве к дорогому человеку. Описывая внешность возлюбленной, лирический герой обращает внимание на богатство ее души, трудолюбие, стойкость. Он осуждает людской мир за распространение плохих качеств, таких, как зависть, обман, ложь, радуется развитию культуры малых народов.

В. Эндип, подобно Рудаки, в четверостишии размещает драматичный сюжет, который достоин произведения большого плана.

- Кӑмӑллатӑп, - терё.

- Ватӑ! - терён.

$Э$ Эс-вунсчичеере. Вӑл-с̧ирёмре.

- Кёт! - ал сулчё... Хёреех суул кётетён.

Эс-сзурас̧нӑ хӗр. Вӑл-с̧ирёмре

[Эндип, 1987, с. 170]

- Нравишься, - сказал.

Сказала: - Староват.

Тебе - семнадиать. Ему - двадиать.

- Жди! - сказал, махнув рукой. Сорок лет уж.

$T \mathrm{~Tb}$ - невеста. Ему - всё двадиать.

В стихотворении использованы короткие диалоги, слова автора. Именные предложения передают диалог молодых людей, их трагическую судьбу. Девушка ведет себя легкомысленно, отвергает дружбу 
молодого человека. Тот, вероятнее всего, уходит в армию и просит дождаться, но погибает. Девушка вот уже 40 лет живет в ожидании. В стихотворении не последняя роль отводится знакам препинания. Тире, восклицательные знаки, многоточие передают вспышки чувств, течение времени и превратности судьбы. Стихотворение строится на контрастах: девушка - парень, молодая - старый, ушел - не вернулся, старая - молодой. Если в начале девушка называет себя молодой, то в конце получается, что она состарилась, а молодой человек навсегда останется в памяти двадцатилетним юношей.

Таким образом, проведенный анализ показал, что в четверостишиях В. Эндипа и Р. Файзуллина наблюдается использование японских и среднеазиатских поэтических традиций. Это проявляется в четверостишиях, описывающих явления природы, повседневной жизни, изображении маленьких деталей, явлений, соединении воедино противоположных понятий. В то же время, авторы соблюдают традиционные для восточного жанра особенности: у Р. Файзуллина это мотивы вина, бренности человеческого бытия, восхваления любви, у В. Эндипа это описание сюжета, характерного для повестей, романов.

Сравнение произведений двух авторов позволяет нам сказать, что в литературах разных народов сходства проявляются в результате увлечения авторов одними и теми же литературными традициями. В данном случае среднеазиатской и японской поэзией. При заимствовании не всегда происходит слепое копирование, поэты сочетают восточный жанр с особенностями родного фольклора, литературы. Заимствуются жанры и традиции, которые близки мировоззрению поэтов, при этом они предполагают наличие соответствующих особенностей в своей литературе.

\section{Библиографический список / References}

Софронова, 2011 - Софронова И.В. Восточные традиции в чувашской лирике // Вестник Чувашского государственного педагогического университета им. И.Я. Яковлева. 2011. № 3-1. С. 193-196. [Sofronova I.V. The Eastern tradition in the Chuvash lyrics. Vestnik Chuvashskogo gosudarstvennogo pedagogicheskogo universiteta im. I.Ja. Jakovleva. 2011. No 3-1. Pp. 193-196.]

Софронова, 2017 - Софронова И.В. Сементерӗн рубаисенчи чӑваш тӗнчи палӑрни [Отображение чувашского мира в рубаях Ю. Сементера] // Национальные языки и литературы в поликультурных условиях: сб. ст. Чебоксары, 2017. Ч. 2. C. 135-139. [Sofronova I.V. Displaying Chuvash world in U. Sementers rubaiyat. Nacional'nye jazyki i literatury v polikul'turnyh uslovijah. Cheboksary, 2017. Vol. 2. P. 135-139.]

Файзуллин, 2012 - Фәйзуллин Р.Г. Мәңгелек мизгел: шигырьлер = Вечность мгновения: стихотворения. Казань, 2012. [Fәjzullin R.G. Vechnost' mgnovenija [Forever now]. Poems. Kazan, 2012.] 
Хузангай, 1987 - Хузангай А.П. Поиск слова: литературно-критические статьи. Чебоксары, 1987. [Huzangaj A.P. Poisk slova: literaturno-kriticheskie stat'i [Word search: literary-critical articles]. Cheboksary, 1987.]

Эндип, 1987 - Эндип В. Самана = Вехи века: Стихотворения, поэмы. Чебоксары, 1987. [Endip V. Samana $=$ Vehi veka [Milestones of the century]. Poems. Cheboksary, 1987.]

Статья поступила в редакцию 6.12.2017

The article was received on 6.12.2017

Софронова Ирина Владимировна - кандидат филологических наук; доцент кафедры чувашской филологии и культуры, Чувашский государственный университет имени И.Н. Ульянова, Чебоксары

Sofronova Irina V. - PhD in Philology; associate professor at the Department of Chuvash Philology and Culture, I.N. Ulyanov Chuvash State University, Cheboksary

E-mail: muxtar2@yandex.ru 


\section{Е.Л. Рудницкая}

Институт востоковедения РАН, 107031 г. Москва, Российская Федерация

\section{Особенности причастий в современном эвенкийском устном языке (по корпусу рассказов 2005-2011 гг.)}

В статье рассматривается употребление одиночных причастий и причастных оборотов в корпусе устных рассказов на эвенкийском языке. Иллюстрируется их употребление и как модификаторов вершинного имени, и как сентенциальных аргументов или обстоятельств. Предлагается анализ причастного оборота в терминах генеративной грамматики.

Ключевые слова: причастие, модификатор, относительное предложение, сентенциальный аргумент, формальный анализ, эвенкийский язык.

10.31862/2500-2953-2018-3-49-68

\section{E.L. Rudnitskaya}

Institute of Oriental Studies, RAS,

Moscow, 107031, Russian Federation

\section{Special features of participles in modern oral Evenki (based on the corpus of oral stories from 2005-2011)}

The paper considers the use of single participles and participial clauses in the corpus of oral stories in Evenki. Their use as head noun modifiers and as sentential complements are illustrated. The formal analysis for participial clauses in terms of generative grammar is proposed. 
Key words: participle, syntax, modifier, relative clause, complement clause, formal analysis, Evenki.

\section{1. Введение}

Категория причастий в принципе считается неоднозначной с точки зрения принадлежности к именной или глагольной категории: обычно у причастий есть и именные, и глагольные свойства. Так, А.А. Шахматов называет причастие «атрибутивно-предикативной» единицей, в то время как прилагательное - атрибутивной единицей [Шахматов, 1952, с. 84]. С. Абней предлагает структуру причастия, состоящую из NP, которая доминирует над VP [Abney, 1987, p. 190]. О.П. Суник отмечает возможность тунгусо-маньчжурского причастия выступать в атрибутивной и предикативной функциях [Суник, 1947, с. 147]. Существует довольно большое число исследований свойств причастий, в частности, в кавказских, алтайских и уральских языках, например [Лютикова, 2001, с. 509; Калинина, 2001a, с. 622-623; Kim, 2004; Сердобольская, Мотлохов, 2009; Сердобольская и др., 2012; Брыкина, Аралова, 2012], а также в типологическом аспекте [Сердобольская, 2005; Shagal, 2017]. В этих исследованиях показано, что причастие в кавказских, финно-угорских и алтайских языках может быть предикатом не только относительного предложения, но и сентенциального актанта. В работе Н.В. Сердобольской, посвященной номинализации, показатель причастия приравнивается к показателю номинализации [Сердобольская, 2008].

Форма, которая в русскоязычных работах по эвенкийскому языку называется причастием, является именной, у нее есть и атрибутивные, и предикативные свойства, и она может быть вершиной сентенциального актанта или обстоятельства. Мы будем использовать для этой формы традиционный термин «причастие».

В настоящей статье мы проиллюстрируем различные синтаксические позиции причастий в корпусе устных эвенкийских текстах (рассказы о жизни и сказки, записанные в 2005-2011 гг. в экспедициях О.А. Казакевич и отглоссированные Е.Л. Клячко [Тексты, 2018]1). В п. 2 иллю-

${ }^{1}$ В корпусе представлены рассказы говоров разных поселков только из северного и южного наречий эвенкийского языка. На более раннем временном срезе [Василевич, 1948] различия между этими наречиями просматривались довольно отчетливо, особенно на уровне фонетики, морфологии и лексики. По исследованию корпуса [Клячко, в печати], эти различия сохранились не полностью: деление на северное и южное наречие остается, но просматривается менее четко. На уровне синтаксиса обоими авторами рассматривались в основном модели управления глаголов, которые варьируются даже в литературном эвенкийском языке. На уровне построения причастного оборота нами не выявлено различий, 
стрируется атрибутивная позиция, в п. 3 - аргументная и обстоятельственная позиции причастия / причастного оборота. В п. 4 обсуждаются сложные и не очень понятные случаи, напоминающие причастный оборот с аккузативным подлежащим. В п. 5 предлагается синтаксическая структура причастного оборота.

Причастия в грамматиках эвенкийского языка упоминаются довольно подробно. В.Д. Колесникова и И.В. Недялков отмечают, что причастие-предикат (и в относительном (релятивном) обороте, и в сентенциальном дополнении) - это чаще всего причастие одновременности (-ri-/-d'Vri-, РтCP.SIM ${ }^{2}$ ), а также, более редко, причастие предшествования (-č $V$-, РтсP.АNT), следования (-d'Vy $V$-, РтCP.POST), перфектное $(-n V$-,

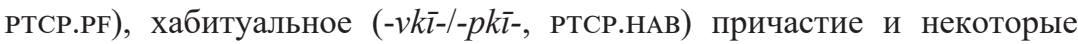
другие $^{3}$ [Колесникова, 1966, с. 200-201; Nedjalkov, 1997, p. 24-27]. И.В. Недялков пишет, что причастный предикат как вершина сентенциального дополнения характерен прежде всего для глаголов ментального состояния ('знать') и непосредственного восприятия ('видеть'), а также для глаголов речи.

В соответствии же с работой Л.М. Бродской, основанной на письменных текстах, включающих северные, южные и восточные говоры, возможны другие модели построения причастного оборота (в плане падежного оформления причастия и вершинного имени и личного согласования причастия) [Бродская, 1988, с. 52-56], которые в исследуемом корпусе найдены не были (см. пп. 2-3).

${ }^{2}$ Глоссы и сокращения: 1, 2, 3 - 1-е, 2-е, 3-е лицо, ABL - аблатив, АCC - аккузатив, ADVZ - показатель адвербиализации, ANT - (причастие) предшествования, CAUS - каузатив, сом - комитатив, COND - условный (конверб), сVB - конверб (деепричастие), DATLOC - датив-локатив, DES - дезидератив, DISTR - дистрибутив, DSPRS - дисперсив, DUR - дуратив, EXCL - эксклюзивное (местоимение множественного числа), FOC - энклитика (частица), маркирующая фокус или коммуникативное выделение, нАв - хабитуалис, HES - показатель хезитации, INCH - инхоатив, INST - инструменталис, INTS - интенсификатор, IPFV - имперфектив, LIM - именной рестриктивный или кванторный (показатель), NEG - отрицание, NFUT - небудущее (время), NMLZ - показатель номинализации, PART - партитив, PASS - пассив, PF - перфектное (причастие), PL - множественное число, PLSTEM - супплетивная форма множественного числа существительного, POST - (причастие) следования с модальным оттенком, PRGRN - перегринатив, PROPR - показатель принадлежности, PS - посессивный (аффикс), PST - прошедшее (время), PROL - пролатив, PTCP - причастие, RFL - рефлексив, SG - единственное число, SIM - (конверб или причастие) одновременности, SLIP - оговорка.

${ }^{3}$ В корпусе рассказов встречаются в основном причастия РТСР.SIм на -ri- (в варианте $-d^{\prime} V r i-$ мы везде глоссируем показатель $-d^{\prime} V$ - как несовершенный вид IPFV). Остальные из перечисленных И.В. Недялковым причастий в единичных случаях встречаются в позиции сказуемого причастного оборота. В то же время, по работе Б.В. Болдырева, основанной на литературном эвенкийском языке, который включает письменные тексты и, в том числе, переводные тексты с русского языка, в этой позиции могут встречаться и некоторые другие причастия [Болдырев, 2007, с. 291]. Те же ограничения (более узкий спектр употребляемых причастий в корпусе в сравнении с литературным языком) относятся и к атрибутивному употреблению, ср. [Болдырев, 2007, с. 464] и примеры в настоящем пункте. 
Другие работы также показывают, что в современном эвенкийском языке причастный оборот - сентенциальное дополнение или относительный оборот свободно взаимозаменимы с финитными клаузами (вводимыми указательными местоимениями в роли «относительных») [Колесникова, 1966, с. 200-201, 227-228; Nedjalkov, 1997, p. 24-26; Grenoble, 2012, p. 103-104]. Финитная клауза, вероятно, является заимствованием из русского языка. В работе Г.М. Василевича финитные придаточные упоминаются только в контексте особой условной формы [Василевич, 1940, с. 164], а в работе Л.М. Бродской, также основанной на текстах начала и середины XX в., примеры финитных придаточных встречаются довольно часто [Бродская, 1988]. Все авторы грамматик также говорят о возможности употребления причастия в эвенкийском в качестве предиката матричного (независимого) предложения [Константинова, 1964, с. 143; Колесникова, 1966, с. 115-116], что характерно для алтайских языков [Калинина, 2001б].

\section{2. Употребление причастий как определений или в качестве вершины относительного (релятивного) оборота}

Употребление причастий как нераспространенных определений составляет подкласс относительных причастных оборотов, в которых у причастия, как у предиката, все аргументы нулевые. Если придерживаться такой точки зрения, причастия, хотя и употребляясь атрибутивно, отличаются от прилагательных, также употребляющихся атрибутивно: своей моделью управления (например, прилагательное не может управлять аккузативом) и морфологическими свойствами (причастия могут включать глагольные залоговые, модальные и аспектуальные аффиксы, стоящие после корня и до числовых/падежных словоизменительных аффиксов, строящихся по принципу именного согласования). В значение самих причастных аффиксов входят определенные таксисные, модальные и аспектуальные значения (причастие предшествования PTCP.ANT $-\check{c} V$-, вероятности РTCP.POST $-d$ ' $V \eta V$, перфекта РTCP.PF $-n V$, хабитуальности РТСР. НАВ - vki--/-pki-, безлично-дебитивное (со значением 'нужно') - $p k \bar{V}-/-v k \bar{V}$-).

И.В. Недялков отмечает, что препозиция вершинного имени к причастному обороту встречается статистически чаще, чем постпозиция, и причастие в постпозиции к вершинному имени может содержать, помимо числового и падежного, также посессивный аффикс [Nedjalkov, 1997, c. 36] (таких примеров в корпусе нет). Необходимо заметить, что в корпусе рассказов развернутые причастные обороты (с зависимыми причастия) встречаются относительно редко: во-первых, причастные обороты нехарактерны для устной речи, во-вторых, многие рассказчики используют 
альтернативную стратегию образования относительного предложения с помощью указательного местоимения и финитного глагола (см. выше).

В корпусе при модификации имени одиночным причастием препозиция причастия является нейтральной и более частотной (1а-б) (как и позиция прилагательного в сочетании с именем), а постпозиция используется при коммуникативном выделении причастия $(1 \mathrm{в})^{4}$ или в случае, когда модифицируемое имя - местоимение $(1 г)^{5}$.

(1) a.

[[bu-mu-li-fkī-1]

умереть-DES-INCH-PTCP.HAB-PL

'Умирающие олени, жалко очень.'

(2008, Кислокан, Удыгир Валентина, РЖ (LR1)6 , 00:01:33.653)

б. aฤi

[[būńī-d’ə-ri-1-wə]

это

вЫТь-IPFV-PTCP.SIM-PL-ACC

dōldīi-rə-w

слышать-NFUT-1PL(EXCL)

'Это, воющих волков мы услышали.'

(2007, Стрелка, Андреева Светлана, РЖ (LR6), 00:01:51.707)

в. baka-mi

найти-CVB.COND

bu-čo-j $\partial^{7}=\mathrm{da}$

умереть-PTCP.ANT-RFL $=$ FOC

oro-r]

олень-PL

hinn'วnə

жалкий

irgiči-l-wə]

волК-PL-ACC

(Надежда ребенком потерялась в лесу) 'Найдешь Надю, живую или мертвую' [букв. 'умершую ли, живущую ли'], (выстрели, это самое, из своей централки, чтобы мы услыхали, что нашлась она.)

(2005, Полигус, Хадончина Надежда, РЖ (LR1), 00:06:19.198)

${ }^{4}$ Можно также предположить, что причина препозиции имени в этом примере - сочинение двух причастий, которые образуют так называемую «тяжелую составляющую», которая обычно переносится вправо, в позицию после вершины. Кроме того, заимствованную из русского ограничительную частицу hot' можно рассматривать как синтаксическое зависимое сочиненных причастий, а причастные обороты (причастия с синтаксическими зависимыми) в корпусе стоят в основном после определяемого имени, см. (2a) и другие примеры ниже.

${ }^{5}$ Согласование причастий в атрибутивной позиции с определяемым ими именем (по категориям числа и падежа) представлено в корпусе практически всегда, cp. [Nedjalkov, 1997, c. 33], в то время как у прилагательных [Константинова, 1964, с. 102] оно факультативно.

${ }^{6}$ PЖ - рассказ о жизни, Ск - сказка, LR, LR1.., LAv, L-transl, FM1..., FSk1 ... - рабочие названия рассказов и сказок в корпусе.

7 При использовании показателя RFL -wi-/-pi-/-ji- (здесь произносится как [jə]), а также показателя RFL.PL $-w V r-/-p V r$-, аффикс аккузатива (- $w V-/-p V$-) стирается [Болдырев, 2007, c. 173]. См. также (4a) или (6б), но не (3д), в котором имя с показателем RFL-ji- (həhən-dū-ji 'рассказ-DATLOC-RFL') 'в рассказе' стоит в дативно-локативном падеже, и показатель RFL следует за показателем DATLOC. 


\section{г. $[\min 2$ om-d'ə-ri-wə] $] \quad$ omōn-čo \\ 1SG.ACC спать-IPFV-PTCP.SIM-ACC оставить-PTCP.ANT \\ 'Меня спящую оставил.' \\ (2005, Полигус, Хадончина Надежда, РЖ (LO), 00:01:08.142)}

Если же от имени зависит причастный оборот, в нашем корпусе чаще встречается его постпозиция (2a) к вершинному имени, чем препозиция (2б). При небольшом общем количестве таких оборотов (около 10-20) можно только заметить, что причастные обороты используются преимущественно в сказках (это также устные тексты, но, рассказывая сказки, носитель старается использовать более архаические конструкции и обороты). Препозитивные причастные обороты были найдены в основном в сказках, единичные случаи. В корпусе чаще представлены примеры, в которых релятивизуется подлежащее. Встретился только один атрибутивный причастный оборот с релятивизуемым дополнением, не совпадающий с вершинным именем - (7a). Согласно работам И.В. Недялкова и Н.В. Сердобольской и др., посессивные аффиксы появляются на причастии для того, чтобы выразить согласование с подлежащим, которое не совпадает с вершинным именем [Nedjalkov, 1997, p. 34, 39, 42; Cepдобольская и др., 2012, с. 410] (это далеко не всегда соблюдается в примерах пп. 2-4). Пример (7а) мы обсудим отдельно в п. 4, в связи с проблемой падежного маркирования подлежащего причастного оборота. Посессивное согласование в нем тоже отсутствует, что, возможно, связано с путаницей падежей.

(2) a. ...[aha-1

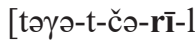
min-nun]]... женщина.PLSTEM-PL сесть-DUR-IPFV-PTCP.SIM-PL $1 \mathrm{SG}-\mathrm{COM}$ (Поняли:) 'женщины, сидящие со мной,' (записали всё, хватит) (2008, Тура, Лапуко Геннадий, РЖ (LR3), 00:11:12.170)

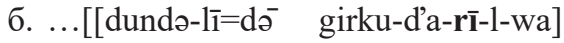
bulta-1-wa]... земля-PROL $=$ FOC $\quad$ ходить-IPFV-PTCP.SIM-PL-ACC добыча-PL-ACC (И птиц [летучих],) 'и по земле ходящих зверей...' (- ничего не оставляет: ни диких оленей, ни лосей) (2007, Чиринда, Елдогир Валентина, Ск (FM2), предложение 5)

\section{3. Причастный оборот как аргумент или обстоятельство}

Употребление причастий и причастных оборотов как аргументов и обстоятельств в литературном эвенкийском языке подробно описано в работе Б.В. Болдырева. Он, как и [Nedjalkov, 1997, p. 30; Сердобольская и др., 2012, с. 406-409], считает причастие именной формой глагола, а причастный аффикс в данном синтаксическом контексте приравнивается к аффиксу номинализации [Болдырев, 2007, с. 291-320]. 
Подлежащее в таком причастном обороте, если оно синтаксически выражено, стоит в именительном падеже (ср. (3в), (3г), (4в-д)); генитива в эвенкийском языке нет; подлежащее-существительное с показателем

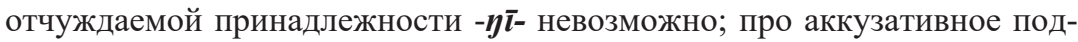
лежащее см. п. 4.

Причастный оборот до некоторой степени похож на посессивную кон-

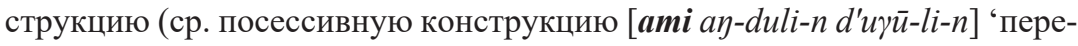
езд отца', вложенную в причастный оборот в (3д)). Причастия вместо лично-притяжательных аффиксов, свойственных финитному глаголу (1SG, 2sG и т.д.), присоединяют притяжательные аффиксы существительных (- $n$ 'PS.3SG' в существительном 'переезд' $d$ 'uүü-li-n в (3д) и в прича-

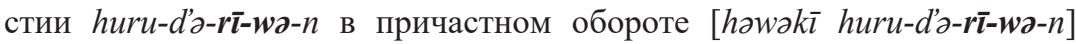
'(пока) Бог уйдет' в (5б)).

Б.В. Болдырев выступает за то, чтобы считать причастную конструкцию эквивалентной притяжательной, в частности, потому что подлежащее при причастии может быть не только существительным в номинативе (без морфологически выраженного падежного окончания), но и притяжательным местоимением с показателем принадлежности -й- (пример

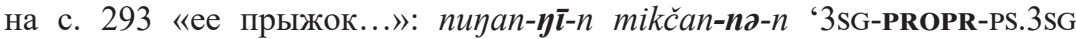
прыжок-PTCP.PF-PS.3SG') [Болдырев, 2007, с. 318, 323-324]. Однако мы не приравниваем эти две конструкции. В исследуемом нами корпусе притяжательные местоимения в сочетании с причастиями или отглагольными существительными, обозначающими действие, не найдены. Мы не будем рассматривать конструкцию с притяжательным местоимением - подлежащим. Скорее всего, такие конструкции действительно являются посессивными ${ }^{8}$.

Посессивная конструкция предусматривает только посессора (который может быть субъектом действия) и обладаемое (в том числе действие), а в причастном обороте имеется глагольная модель управления и могут быть другие члены предложения (ср. прямое дополнение в (3a), (4a) и обстоятельство в (4б)). Исходя из указанных выше соображений, мы в причастном обороте не рассматриваем отдельно группу «подлежащее и причастие» как аналог посессивной конструкции, а рассматриваем любую конструкцию с причастием как сентенциальную структуру с подлежащим в номинативе. Таким образом, первостепенную

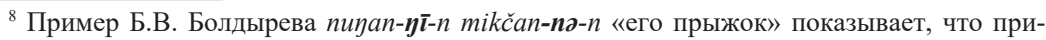
частная конструкция близка к притяжательной. В работе О.А. Константиновой даются примеры на аналогичные конструкции как посессивные с так называемыми «субстантивированными» причастиями [Константинова, 1964, с. 83]. При описании посессивной конструкции и причастных оборотов у И.В. Недялкова и В.Д. Колесниковой примеры с притяжательными местоимениями и причастиями (отглагольными именами) не найдены [Nedjalkov, 1997, p. 82-83, 268-270; Колесникова, 1966, с. 101-102, 199-202]. 
роль в нашем анализе играет модель управления номинализованного глагола'.

Если в примерах (3a) и $(3 г)^{10}$ аргумент, выраженный причастием и его зависимыми, можно восстановить из контекста и считать нулевым ('(хорошо знающих землю) людей', '(этих воющих страшно) волков'), то в примерах (3б-в), (3д) нет того аргумента, который релятивизуется, поскольку сам причастный оборот является аргументом (ср. конструкцию 'то, что $\mathrm{S}$ ' в русском $)^{11}$. Стоит также привести пример (3д), в котором аргумент матричного глагола 'забыть' - причастие следования/ вероятности РтCP.POST на $-d^{\prime} V y V$ - (такие примеры единичны $)^{12}$.

${ }^{9}$ Как видно из примера (i), номинализованный глагол с показателем -с̌ən- (по [Василевич, 1958, с. 756], это «глагольно-именная форма процесса действия»), не относящийся к причастиям, может иметь не только подлежащее, но и дополнение (при присоединении показателя рефлексива к дополнению типа $\dot{\sigma} \gamma u-j u$ «передового оленя» показатель аккузатива стирается, см. пример (1в) и сноску 7). Мы видим, что строго доказать, что даже распространенный причастный оборот - не частный случай именной конструкции, нельзя.

(i) ...tolgokī-duk=to-pi jū- Ø-m санки-ABL=FOC-RFL $\quad$ выйти-NFUT-1SG

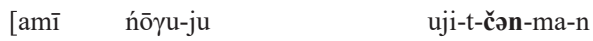

отец передовой.олень-RFL привязать-DISTR-NMLZ.DUR-ACC-3SG пока

'Я вышла из своих санок, пока отец привязывал передового оленя.'

(2011, Хантайское озеро [CH], Еремина Любовь, 00:10:22.811)

${ }^{10}$ Причастие предшествования РтCP.ANT $b i-s^{\prime} \bar{o}-l$ в (3а) и $i ъ ə-f k d-b i-l-u o$ в (3г) - это случаи употребления причастия в качестве матричного предиката (см. также примеры (4в-г), (5б), (6б)). В (3б) ayi-d’ə-ri-l-wə 'это делающих' - причастие, образованное от основы местоимения ауі. Глагольные формы, образованные от именных основ, часто встречаются в эвенкийском языке.

${ }^{11}$ И.В. Недялков дополнительно утверждает, что по крайней мере аргументные причастные обороты - это безвершинные относительные предложения (headless relative clauses) [Nedjalkov, 1997, c. 37-38]. В работе [Cinque, 2016, p. 15] отмечается, что безвершинные относительные придаточные обязательно должны быть финитными. Примеры, приводимые И.В. Недялковым и встречающиеся в рассказах, нельзя однозначно соотнести с русскими безвершинными относительными предложениями. «Условию совпадения» (matching condition) Дж. Гримшо [Лютикова, 2015, с. 76] соответствует в эвенкийских причастных конструкциях необходимость порождения причастной клаузы (с проекцией падежа КР) в аргументной или обстоятельственной позиции главного предложения, в которой эта клауза получает имеющийся у нее падеж (ср. [Лютикова, 2016, т. 1, с. 282]). Это условие теоретически может также удовлетворяться через введение нулевого вершинного имени в (3а), (3г), (4а-г); этот вопрос кажется не до конца ясным.

12 Если в (3б-в), (3д) матричный глагол - глагол непосредственного восприятия или ментальный предикат, то в (3а) и (3г) матричный глагол не входит ни в один из семантических классов глаголов, допускающих сентенциальные дополнения, приводимых И.В. Недялковым (см. Введение). Такие причастные обороты в работе [Csató, Muzappar, 1997$, p. 72$]$ на материале уйгурского языка называются безвершинными (ср. сноску 11). В архиве, в который входят более ранние рассказы (1940-1950-х гг.) [Лебедева, 1952], дополнения - причастные обороты встречаются в контекстах типа (3a), (3г) чаще, чем в современном корпусе рассказов. Можно сделать предположение о влиянии лексико-синтаксического строя русского языка на эвенкийский: множество матричных глаголов, с которыми употребляется дополнение-причастный оборот, сужается. 


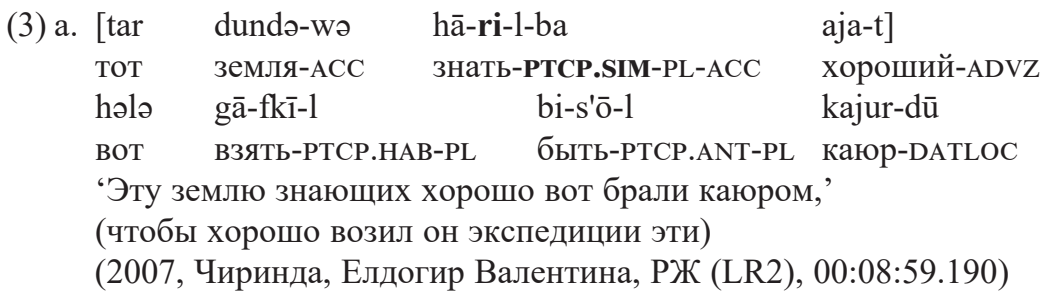
б. bi tar dōldī- $\varnothing-m$ [ani-d’ə-ri-l-wə
$1 \mathrm{SG}$ тот слышать-NFUT-1SG это-IPFV-PTCP.SIM-PL-ACC būñi-d’ə-ri-l-wə straš выть-IPFV-PTCP.SIM-PL-ACC страшный.SLIP страшный-INTS 'Я это услышала, этих [букв. 'это делающих'] воющих страшно.' (2007, Стрелка, Андреева Светлана, РЖ (LR6), 00:02:52.122)

в. dōldī-rə-Ø [əntil-tin слышать-NFUT-3PL родитель.PL-PS.3PL jōkə-d'ə-rī-l-wə] кричать-IPFV-PTCP.SIM-PL-ACC (младшие братья и сестры Нади) 'услышали крики родителей.' (2005, Полигус, Хадончина Надежда, РЖ (LR1), 00:03:48.711)

г. tar hələ iśə-fkō-śi-l-čo tar тот вот видеть-CAUS-DISTR-INCH-PTCP.ANT TOT [ига-na-l-bi] нести-PTCP.PF-PL-RFL (человек вернулся домой) 'Вот он стал показывать то, что принес...' (2007, Чиринда, Елдогир Валентина, Ск (FSk10) предложение (77), 05:20-05:23)

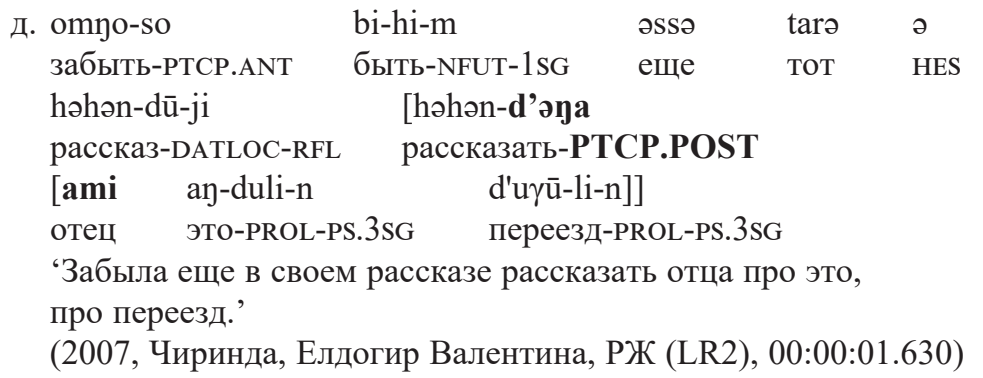

Обстоятельственные причастные предложения строятся так же, как аргументные, только падеж причастия выражает то обстоятельственное отношение, которое связывает главную и придаточную клаузу. Так, аблатив в (4а) обозначает причину [Константинова, 1964, с. 56]; 
пролатив в (4б) обозначает предел времени, по истечении которого имеет место ситуация [Константинова, 1964, с. 53-54]. Для дативно-локативного падежа в (4в) нормально обозначать место действия; аккузатив в (4г) маркирует причастное зависимое наречия оji 'наверху', которое может функционировать как послелог: согласно [Константинова, 1964, с. 248], наречия-послелоги все управляют аккузативом. Интересно, что уступительное отношение в (4д) также маркируется аккузативом ${ }^{13}$.

(4) a. [halgan-mi

monnokot-š'ə-nə

нога-RFL

баловаться-IPFV-CVB.SIM

kapu-t-na-duki-w]

kamisəvali

сломать-DUR-PTCP.PF-ABL-PS. 1SG

комиссовали

'Из-за того, что я ногу, балуясь, сломал, комиссовали.'

(2007, Эконда, Удыгир Виктор, РЖ (LAv), 00:03:18.485)

б. [bira-1-dū urin-nə-lī]

река-PL-DATLOC

стать.на.однодневную.стоянку-PTCP.PF-PROL

bira-t $=$ tə umukō-t-t'ə-d'ə-rə-Ø

река-INSTR $=$ FOC

один-VBLZ-IPFV-IPFV-NFUT-3PL ${ }^{14}$

(речь о том, в какие игры играли дети) 'Когда останавливались на реках, [забавляются] с рекой по одному' [букв. 'делают чтото с рекой в одиночестве'] (...камушками играют)

(2007, Эконда, Комбагир Анна, РЖ, 00:34:29.051)

\begin{tabular}{|c|c|c|}
\hline в. tadū hoj-dū & təүə-w & təүə-w \\
\hline 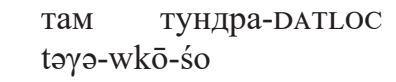 & $\begin{array}{l}\text { сесть-CAUS.SLIP } \\
\text { [d'u-n }\end{array}$ & сесть-CAUS.SLIP \\
\hline $\begin{array}{l}\text { сесть-СAUS-PTCP.ANT } \\
\text { iśə-W-rī-d̄̄u ] }\end{array}$ & дом.чум-PS.3SG & \\
\hline $\begin{array}{l}\text { видеть-PASS-PTCP.SIM-DA } \\
\text { (Пленник Кингита заста } \\
\text { по воздуху) 'Там на тун } \\
\text { его чум.' (2007, Чиринд } \\
\text { предложение } 112 \text { ) }\end{array}$ & $\begin{array}{l}\text { цос } \\
\text { ил детей Кингитс } \\
\text { pe он их посадил } \\
\text { Елдогир Валент }\end{array}$ & $\begin{array}{l}\text { тнести его домой } \\
\text { де был виден } \\
\text { a, Ск (FSk9), }\end{array}$ \\
\hline
\end{tabular}

${ }^{13}$ Такую многофункциональность аккузатива можно связать с тем, что, в соответствии с [Василевич, 1948, с. 129], показатель $-w V-/-m V-$ АСС (определенный аккузатив) в литературном эвенкийском языке (созданном в 1930-х гг.) и в некоторых говорах маркировал семантическую роль не только пациенса, но также причины, цели и др., что также отражается и в корпусе рассказов. Важно заметить, что в корпусе практически не встречается опущение показателя $\mathrm{ACC}$, в то время как в начале XX в. в разговорной речи такое опущение в некоторых говорах встречалось. Сейчас неопределенность или нереферентность маркируется партитивным падежом -jV- PART, ср. (6б).

${ }^{14} \mathrm{~B}$ данной словоформе дважды повторяется один и тот же аффикс IPFV (-t’-d’z-). Такое удвоение характерно именно для идиолекта Анны Комбагир и используется ею для усиления или эмфатического выделения. Вероятно, такая особенность связана с тем, что родной язык Анны - якутский, а в якутском есть усилительные конструкции, использующие 


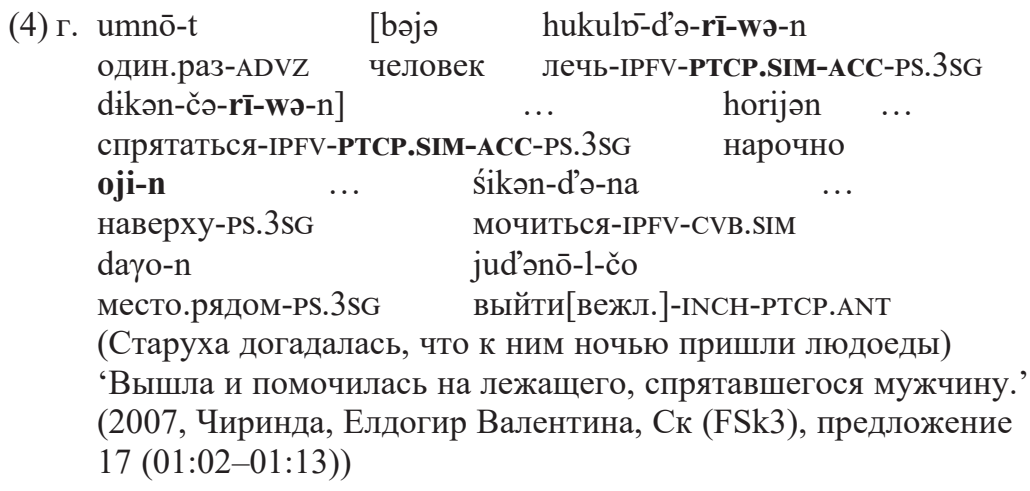

д. to 0 -rikta-tin $\operatorname{tar}$ огонь-LIM-PS.3PL TOT [bi bi-d'ə-rī-wo 1SG быть-IPFV-PTCP.SIM-ACC здесь hinkərī-d'ə-rə-n трещать(об.огне)-IPFV-NFUT-3SG ədū]

(Мужчина попал на «нижнюю землю», и ее обитатели его не замечали) 'Только огонь у них [в чуме] трещит, хотя я здесь.’ (2007, Елдогир Валентина, Ск (FSk10), предложение 25 (01:53-01:57)

В нашем материале все сентенциальные дополнения и обстоятельства, выраженные причастным оборотом, оформляются одинаково. О возможном отсутствии падежного показателя у причастия в причастном обороте (при релятивизации прямого или косвенного дополнения) упоминается в работах [Бродская, 1998, с. 52-54; Nedjalkov, 1997, p. 41-42]: такие примеры были найдены Л.М. Бродской в некоторых говорах северного наречия. Также возможны случаи (расцениваемые Л.М. Бродской как инновации), когда причастие присоединяет падеж, присваиваемый глаголом придаточного предложения, который должно нести нулевое относительное местоимение. В корпусе ни в одном говоре такие примеры не найдены, как и в примерах В.Д. Колесниковой [Колесникова, 1966, с. 201].

Посессивное согласование с подлежащим причастного оборота - сентенциального дополнения в корпусе рассказов соблюдается далеко не во всех случаях (см. ссылки на работы И.В. Недялкова и Н.В. Сердобольской в п. 2). В нашем материале согласование есть только при матричных предикатах речи (5a-в) и еще в нескольких примерах $\left((4 a),(6 a),(66)^{15}\right)$.

${ }^{15} \mathrm{~B}(6 б)$ причастие әтә-ri-jō- $n$ 'прихода' согласуется по единственному числу $-n$ PS.3SG, а подлежащие матричного и придаточного предложений стоят во множественном числе это видно по согласованию причастия в матричном предложении ‘ждали' и подлежащему причастного оборота с показателем RFL.PL: yinakin-mər. Это, возможно, ошибка. Также

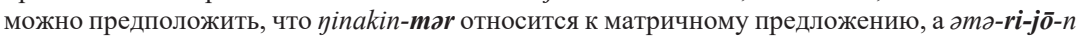
'прихода' интерпретируется как имя (субстантивированное причастие), а не вершина причастного оборота (см. сноску 8). 
Таким образом, в корпусе среди атрибутивных причастий и причастных оборотов посессивное согласование не найдено, а среди сентенциальных дополнений и обстоятельств встречается достаточно редко. Поскольку в корпусе вообще мало причастных оборотов, особенно в атрибутивной функции, а в работе [Nedjalkov, 1997, p. 33-34, 39] приводятся примеры на посессивное согласование причастия с подлежащим атрибутивного причастного оборота (при релятивизации прямого дополнения), мы не делаем вывод, что посессивное согласование в атрибутивном обороте запрещено. По нашему корпусу, в причастном обороте - сентенциальном дополнении или обстоятельстве - посессивное согласование теряет свою обязательность, а в атрибутивных причастных оборотах это согласование возможно из общих соображений.

\section{4. Оформление подлежащего в причастном предложении}

Как уже говорилось во введении, наиболее часто причастные обороты встречаются (в том числе в корпусе) как сентенциальные дополнения глаголов ментального состояния, непосредственного восприятия, речи. Во всех этих случаях подлежащее обычно стоит в номинативе, как в примерах (5а-в) (см. более подробную дискуссию в п. 3).

(5) a. [on dəgi on ... gun-d’ə-rī-wə-n dəgi] как птица как сказать-IPFV-PTCP.SIM-ACC-PS.3SG птица hā-Ø-ndə знать-NFUT-2SG

'Как птица, как говорит птица, знаешь?' (2007, Чиринда, Елдогир Валентина, Ск (FSk2), предложение 38)

б. [həwək̄̄ huru-d’ə-rī-wə-n] isə-t-čo Бог пойти-IPFV-PTCP.SIM-ACC-PS.3SG видеть-DUR-PTCP.ANT (Черт ждал, пока Бог уйдет, чтобы навредить людям)

'Он видел, как Бог уходит.' (2007, Чиринда, Елдогир Валентина, Ск (FM1), предложение 34)

в. əhī-kokōn həhən-d’ə’ō-w [hēyan hēyan hulan-nun сейчас-INTS рассказать-FUT-1SG налим налим лиса-сом gōkčan-na-wa-tin] соревноваться-PTCP.PF-ACC-PS.3PL

'Сейчас расскажу, как налим, налим с лисицей соревновались.' (2007, Чиринда, Елдогир Валентина, Ск (FM7), предложение 1)

Несколько примеров допускают трактовку подлежащего как стоящего в аккузативе, причем это подлежащее одновременно является дополнением матричного глагола, например, (6а-б). Если внешне эти 
предложения напоминают калмыцкую конструкцию с подъемом [Сердобольская, 2009], то [Nedjalkov, 1997, с. 33] анализирует такие предложения как относительные с аккузативным именем - аргументом матричного глагола и вершинным именем. Поскольку в корпусе крайне мало предложений такого рода, можно только предположить, что более правильным для эвенкийского является анализ И.В. Недялкова. Так, (6а) можно интерпретировать как «(Геолог) вспоминала отца с матерью, которые хорошо ее возили». Аналогично интерпретируется yinakin-mər с показателем -mər RFL.PL (прямой объект, см. сноску 7) в (6б), стоящее в начале предложения и отделенное от причастия матричным глаголом.

(6) a. luhu d'ońt'a-d'a-rə-n d'ońta-d'a-sā-n все.время вспомнить-IPFV-NFUT-3SG [aja-t əksə-ktə-nə-wə-tin] вспомнить-IPFV-PST-3SG хороший-ADVZ везти-DSPRS-PTCP.PF-ACC-PS.3PL мать-COM-ACC amī-wa отец-АCC

(Отец и мать Валентины работали проводниками у геологов. Одна женщина-геолог осталась довольна.)

'Все время вспоминала, как хорошо возили [ее] отец с матерью’ (2007, Чиринда, Елдогир Валентина, РЖ (LR2), 00:09:28.150)

б. [ninakin-mər] alās'i-1-ča-1 собака-RFL.PL ждать-INCH-PTCP.ANT-PL [əmə-ri-jōon]

прийти-PTCP.SIM-PART-PS.3SG

'Прихода своих собак стали они ждать' [или 'Своих собак они стали ждать, приходящих'] (2007, Чиринда, Елдогир Валентина, РЖ (LR2), 00:03:55.550)

Примеры (6а-б) теоретически допускают трактовку әńi-nun-mə am̄̄-wa 'отца с матерью' и yinakin-mər 'собаки' как аккузативных подлежащих причастной клаузы. Рассмотрим (6а). В эвенкийских рассказах позиция в конце предложения полуактивированного участника дискурса [Chafe, 1984, с. 122] или темы (как номинативного подлежащего, так и аккузативного дополнения) представлена очень широко [Рудницкая, 2017], при этом в основном в матричных предложениях. Эта закономерность есть в разных языках типа SOV ([Göksel, 2013] в отношении турецкого языка и [Polinsky, 2015, c. 432-435] в отношении цезского языка). Примеров на причастный оборот с конечным подлежащим в корпусе не найдено.

Рассмотрим (6б). Начальная позиция в предложении, согласно [Василевич, 1940, p. 143-144; Nedjalkov, 1997, p. 29-30], в эвенкийском языке 
может быть позицией эмфатического выделения или контрастного фокуса. Можно предположить, что ninakin-mər 'собаки' в (6б) - контрастный топик. Таким образом, из материала (6а-б) нельзя сделать определенных выводов о коммуникативном выделении при маркировке подлежащего аккузативом ${ }^{16}$.

Кроме того, в рассказах Хадончиной Надежды (Полигус) найден пример аккузативного подлежащего в релятивном причастном обороте (ср. (7a)). Если анализировать (7а) так, как это показано с помощью квадратных скобок, в относительное придаточное входит и аккузативное подлежащее (yinaki-r-wo), и аккузативное дополнение (mōti-wo). Но после (7a) в тексте сразу следует (7б) с финитным относительным оборотом, в котором номинативное подлежащее (ninaki-r) и аккузативное дополнение (вопросительное слово $\bar{k} k u-\boldsymbol{r}-\boldsymbol{w a}$ 'что/кого, на что/кого'), т.е. рассказчик Надежда поняла, что сделала ошибку, и исправилась ${ }^{17}$.
(7) a. suru-čo
$\operatorname{tar}$
mōtī-wo
пойти-РТСР.АNT тот
лось-АСC
[ninaki-r-wə
gowo-d'ə-ri-l-wo
собака-PL-ACC
лаять-IPFV-PTCP.SIM-PL-ACC
mōtī-wo]
wā-nā-s-tə-n
лось-АСС
убить-PRGRN-INCH-NFUT-3SG
(речь идет об отце Надежды) 'Пошел (чтобы) добыть
того лося, того лося, на которого лаяли собаки'
(2005, Полигус, Хадончина Надежда, РЖ (LO), 00:01:00.720)
б. mōtī-wo
лось-АCC
iče-nō-s-čo
[ēku-r-wa
увидеть-PRGRN-INCH-PTCP.ANT
чTO-PL-ACC
jinaki-r
gowo-d'o-ro- $\varnothing]$
‘Лося пошел поглядеть, на кого собаки лают' (00:01:05.028).

\footnotetext{
${ }^{16}$ Если учитывать данные из сноски 13 , коммуникативное выделение не должно входить в функции аккузатива; это подтверждается и закономерностями употребления аккузатива в корпусе рассказов (скорее просматривается аккузатив с расширенной сферой употребления).

${ }^{17}$ Найдено предложение (i), в котором аккузативную форму принимает подлежащее финитного придаточного. Однако рассказчица Андреева, как и Хадончина в (7а-б), в следующем предложении исправляет аккузативную форму на номинативную.
}

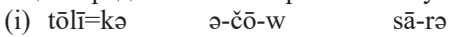
тогда=FOC NEG-PST-1SG знать-PTCP.NEG

[tar d'antakī-wə awadi bi-čō-n]

тот росомаха-АсC какой быть-PST-3sG

'Тогда не знала, та росомаха какая.' (2007, Стрелка [ЮН], Андреева Светлана, 
В целом очень скудный материал не дает возможности предположить существование аккузативного подлежащего в разговорном эвенкийском языке, так что вышеизложенный анализ И.В. Недялкова (аккузативная группа порождается в матричном предложении) представляется правильным.

\section{5. Синтаксический анализ причастного оборота}

Учитывая имеющиеся работы по анализу причастных оборотов и по сентенциальным номинализациям [Abney, 1987, p. 190; Гращенков, Лютикова, 2008, с. 202; Doron, Reintges, 2005, p. 19-20; Baker, 2011, p. 1183; Volkova, 2017, p. 13; Dékány, Tánczos, 2017] и др., можно предложить, что структура причастной клаузы - сентенциального дополнения следующая. Поскольку в причастной клаузе PtcpР возможно прямое дополнение (ср. (3a)), в ней есть проекция $v$ Р. В ее спецификаторе объекту $\mathrm{NP}_{\text {овJ }}$ присваивается аккузатив. Глагол V при номинализации должен подвергнуться инкорпорации в Ptcp (как именная вершина, Ptpl в [Baker, 2011])). Кроме того, причастная словоформа из Рtср передвигается в К (для присваивания ей падежа) и далее в Poss (для согласования с подлежащим причастной клаузы). Подлежащее причастной клаузы $\mathrm{NP}_{\text {SUBJ }}$ порождается в SресТР причастной клаузы, где ему присваивается именительный падеж (ср. [Лютикова, 2016, т. 2, с. 290]). Для согласования с ним глагола подлежащее передвигается в SpecPtcpP, затем в SpecKP, затем в SpecPossP (HP по [Baker, 2011, p. 19]). В (8) показана структура (5в) в виде дерева.

Данная структура показывает только приблизительную схему анализа причастного оборота - сентенциального дополнения или обстоятельства (эту схему мы предлагаем и для атрибутивного причастного оборота). Доминирующей проекцией является PossP из-за именной природы причастной клаузы и потому что показатель согласования в именной словоформе стоит на последнем месте, после показателя падежа, cp. gun-d'ə-rī-wo-n 'сказать-IPFV-PTCP.SIM-ACC-PS.3SG' '(как птица) говорит' в (5a). В (8) не всегда заполнена проекция PossP. Посессивное согласование далеко не всегда соблюдается, и при отсутствии такого согласования не требуется кореферентности подлежащих главной и причастной клаузы (см. (3в-г), (4в) выше). В этих случаях не может быть использован анализ с «реструктурированием» (restructuring, [Baker, 2011, p. 1197ff].

В причастном обороте РtсpР в (8) используется левостороннее, а не правостороннее ветвление, потому что в соответствии со статистикой, в придаточных предложениях в корпусе рассказов порядок OV встречается намного чаще, чем в главных (см. таблицу 1 в работе [Рудницкая, 2017, с. 24]). Мы также не вводим проекцию СР; это связано со следующим: 
1) мы не используем универсальную схему придаточного относительного [Kayne, 1994];

2) подлежащее причастного оборота не может стоять в генитиве (см. [Лютикова, 2016, т. 1, с. 149]);

3) нефинитный характер причастного оборота;

4) в нашем материале почти нет причастных вопросительных предложений (ср. (5a)), в общем случае вопросительное слово, по нашему мнению (см. [Рудницкая, 2017, с. 63-64]), стоит в позиции SpecFocP, a не $\mathrm{SpecCP}^{18}$.

(8) (cp. (5в): [hēnan hulan-nun gōkčan-na-wa-tin)

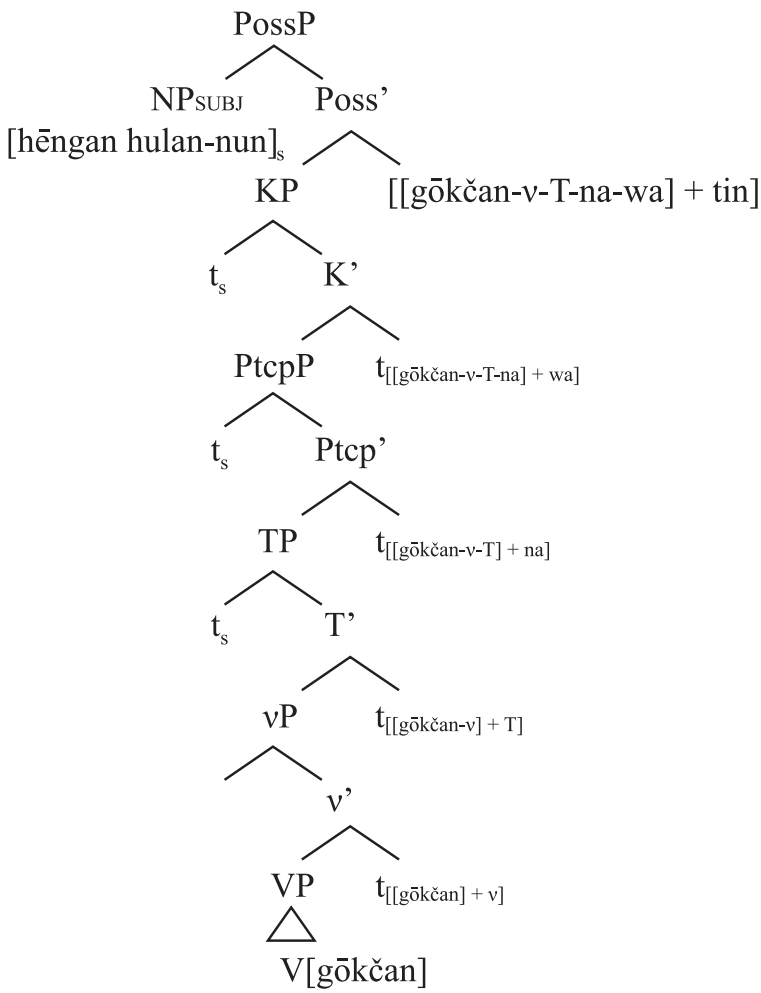

${ }^{18}$ Вершина D и проекция DP (вместо CP) для относительных придаточных также могла бы обеспечивать согласование падежного признака вершины К в причастной клаузе с признаком той фонологически выраженной или нулевой $\mathrm{NP}$, которая является вершиной придаточного: нулевой NP - в случае (За), (Зг) и, предположительно, в случае обстоятельственной причастной клаузы (4а-в), если считать причастные обороты в этих случаях также безвершинными относительными предложениями. В нашей схеме за согласование с вершинным именем отвечает KP, а не DP, хотя для употребления причастных оборотов как относительных придаточных это спорно. См. сноски 11-12. 
В соответствии с данными п. 3, мы анализируем обстоятельственные причастные обороты и сентенциальные дополнения одинаково. По данным п. 2 и грамматик, так же следует анализировать и атрибутивный причастный оборот. Во всех этих случаях причастие имеет проекцию $\mathrm{KP}$, в которой (исходя из факторов глагольного управления, согласования, синтаксической роли в предложении) определяется падеж причастия. Можно сделать общий вывод о тенденции современного устного эвенкийского языка к упрощению и исчезновению структурной вариативности (в частности, в структуре причастного оборота), а также о влиянии на речь рассказчиков разных говоров общего для всех литературного языка (его многие рассказчики учили в школе), в котором эта вариативность отсутствует.

\section{Библиографический список / References}

Болдырев, 2007 - Болдырев Б.В. Морфология эвенкийского языка / Роббек В.А. (ред.). Новосибирск, 2007. [Boldyrev B.V. Morfologiya evenkiiskogo yazyka [Morphology of the Evenki language]. V.A. Robbek (ed.). Novosibirsk, 2007.]

Бродская, 1988 - Бродская Л.М. Сложноподчиненное предложение в эвенкийском языке. Новосибирск, 1988. [Brodskaya L.M. Slozhnopodchinennoe predlozhenie v evenkiiskom yazyke [Complex sentence in Evenki]. Novosibirsk, 1988.]

Брыкина, Аралова, 2012 - Брыкина М.М., Аралова Н.Б. Системы причастий в марийском и пермских языках // Финно-угорские языки: фрагменты грамматического описания. Формальный и функциональный подходы. М., 2012. С. 476520. [Brykina M.M., Aralova N.B. Particle systems in Mari and Permian languages. Finno-ugorskie yazyki: fragmenty grammaticheskogo opisaniya. Formal'nyi i funktsional'nyi podhody. Moscow, 2012. Pp. 476-520.]

Василевич, 1940 - Василевич Г.М. Очерки грамматики эвенкийского (тунгусского) языка. Л., 1940. [Vasilevich G.M. Ocherki grammatiki evenkiiskogo (tungusskogo) yazyka [Essays on Evenki (Tungus) grammar]. Leningrad, 1940.]

Василевич, 1948 - Василевич Г.М. Очерки диалектов эвенкийского (тунгусского) языка. Л., 1948. [Vasilevich G.M. Ocherki dialektov evenkiiskogo (tungusskogo) yazyka [Essays on Evenki (Tungus) dialects]. Leningrad, 1948.]

Василевич, 1958 - Василевич Г.М. Эвенкийско-русский словарь. М., 1958. [Vasilevich G.M. Evenkiisko-russkii slovar' [The Evenki-Russian dictionary]. Moscow, 1958.]

Гращенков, Лютикова, 2008 - Гращенков П.В., Лютикова Е.А. Номинализация и семантико-синтаксический интерфейс // Исследования по глагольной деривации / Плунгян В.А., Татевосов С.Г. (ред.). М., 2008. С. 171230. [Grashchenkov P.V., Lyutikova E.A. Nominalization and the syntax-semantics interface. Issledovaniya po glagol'noi derivatsii. Plungian V.A., Tatevosov S.G. (eds.). Moscow, 2008. Pp. 171-230.] 
Калинина, 2001а - Калинина Е.Ю. Актантные предложения // Багвалинский язык. Грамматика. Тексты. Словари / Кибрик А.Е. (ред.). М., 2001. С. 512-553. [Kalinina E.Yu. Argument complex sentences. Bagvalinskii yazyk. Grammatika. Teksty. Slovari [Bagwalal. Grammar. Texts. Dictionaries]. Kibrik A.E. (ed.). Moscow, 2001. Pp. 512-553.]

Калинина, 2001б - Калинина Е.Ю. Нефинитные сказуемые в независимом предложении. М., 2001. [Kalinina E.Yu. Nefinitnye skazuemye v nezavisimom predlozhenii [Non-finite predicates in main clauses]. Moscow, 2001.]

Клячко, в печати - Клячко Е.Л. Диалектные особенности публикуемых текстов // История страны в рассказах о жизни кетов, селькупов и эвенков / О.А. Казакевич, Е.М. Будянская, Ю.Е. Галямина, Е.Л. Клячко. В печати. [Klyachko E.L. Dialect features of the published texts. O.A. Kazakevich, E.M. Budyanskaya, E.Yu. Galyamina, E.L. Klyachko. Istoriya strany v rasskazax o zhizni ketov, sel'kupov i evenkov. In press.]

Колесникова, 1966 - Колесникова В.Д. Синтаксис эвенкийского языка. M., 1966. [Kolesnikova V.D. Sintaksis evenkiiskogo yazyka [Syntax of Evenki]. Moscow, 1966.]

Константинова, 1964 - Константинова О.А. Эвенкийский язык. Фонетика. Морфология. М., 1964. [Konstantinova O.A. Evenkiiskii yazyk [Evenki]. Moscow, 1964.]

Лебедева, 1952 - Лебедева Е.П. Тексты на эвенкийском языке, записанные в экспедиции 1952 г. // Архив Института лингвистики РАН. Рабочие материалы Е.П. Лебедевой. Тетрадь 102. [Lebedeva E.P. Teksty na evenkiiskom yazyke, zapisannye v ekspeditsii 1952 g. [Texts in Evenki written down in the expedition in 1952]. Ms. Working Papers of E.P. Lebedeva. Notebook 102. Institute of Linguistic Studies of the Russian Academy of Sciences archive.]

Лютикова, 2001 - Лютикова Е.А. Относительное предложение // Багвалинский язык. Грамматика. Тексты. Словари / Под ред. А.Е. Кибрика. М., 2001. C. 491-511. [Lyutikova E.A. Relative clause. Bagvalinskii yazyk. Grammatika. Teksty. Slovari [Bagwalal. Grammar. Texts. Dictionaries]. Kibrik A.E. (ed.). Moscow, 2001. Pp. 491-511.]

Лютикова, 2015 - Лютикова Е.А. Безвершинные относительные предложения в русском языке: эмпирические данные и теоретические проблемы // Rhema. Рема. 2015. № 3. C. 74-85. [Lyutikova E.A. Headless relative clauses in Russian: Empirical data and theoretical considerations. Rhema. Rema. 2015. № 3. Pp. 74-85.]

Лютикова, 2016 - Лютикова Е.А. Синтаксис именной группы в безартиклевом языке: Дис. ... д-ра филол. наук. М., 2016. [Lyutikova E.A. Sintaksis imennoi gruppy v bezartiklevom yazyke [Noun Phrase syntax in languages without articles]. Dokt. diss. Lomonosov Moscow State University, 2016.]

Малые языки, 2018 - Малые языки Сибири: наше культурное наследие. Выложила Е.Л. Клячко. URL: http://siberian-lang.srcc.msu.ru/ [Malye yazyki Sibiri: nashi kul'turnoe nasledie [Small languages of Sibiria: our cultural heritage]. E.L. Klyachko (ed.). URL: http://siberian-lang.srcc.msu.ru/]

Рудницкая, 2017 - Рудницкая Е.Л. Актуальное членение и порядок слов в устном эвенкийском языке (на материале устных рассказов на эвенкийском 
языке 2005-2011 гг.). Beau Bassin, 2017. [Rudnitskaya E.L. Aktual'noe chlenenie $\mathrm{i}$ poryadok slov $\mathrm{v}$ evenkiiskom yazyke [Information structure and word order in Evenki]. Beau Bassin, 2017.]

Сердобольская, 2005 - Сердобольская Н.В. Синтаксический статус актантов зависимой нефинитной предикации: Дис. ... канд. филол. наук. М., 2005. [Serdobol'skaya N.V. Sintaksicheckii status aktantov zavisimoi nefinitnoi predikatsii [Syntactic status of the arguments in a non-finite dependent clause]. $\mathrm{PhD}$ diss. Lomonosov Moscow State University, 2005.]

Сердобольская, 2008 - Сердобольская Н.В. Номинатив в номинализации: субъект зависимой предикации или именное зависимое // Исследования по глагольной деривации / В.А. Плунгян, С.Г. Татевосов (ред.). М., 2008. С. 314-348. [Serdobol'skaya N.V. Nominative and nominalization: Subject of a dependent clause or nominal complement]. Issledovaniya po glagol'noi derivatsii. Plungian V.A., Tatevosov S.G. (ed.). Moscow, 2008. Pp. 314-348.]

Сердобольская, 2009 - Сердобольская Н.В. Аккузатив субъекта в зависимой предикации: за и против подъема аргумента в калмыцком языке // Исследования по грамматике калмыцкого языка / Казанский Н.Н. (отв. ред.). СПб., 2009. C. 581-622. [Serdobol'skaya N.V. Accusative of the subject in a dependent clause: For and against the raising of an argument in Kalmyk. Issledovaniya po grammatike kalmytskogo yazyka. N.N. Kazanskii (ed.). Saint-Petersburg, 2009. Рp. 581-622.]

Сердобольская, Мотлохов, 2009 - Сердобольская Н.В., Мотлохов А.В. Семантика конструкций с сентенциальными актантами в адыгейском языке // Аспекты полисинтетизма: очерки по грамматике адыгейского языка / Тестелец Я.Г. (отв. ред.). М., 2009. С. 498-559. [Serdobol'skaya N.V., Molotkhov A.V. Semantics of sentential argument constructions in Adighe. Aspekty polisintetizma: ocherki po grammatike adygeiskogo yazyka. Ya.G. Testelets (ed.). Moscow, 2009. Pp. 498-559.]

Сердобольская и др., 2012 - Конструкции с сентенциальными актантами в финно-угорских языках / Сердобольская Н.В., Ильевская А.А., Минор С.А. и др. // Финно-угорские языки: фрагменты грамматического описания. Формальный и функциональный подходы. М., 2012. С. 382-476. [Serdobol'skaya N.V., Ilyevskaya A.A., Minor S.A. et al. Sentential argument constructions in Finno-Ugric languages. Finno-ugorskie yazyki. Formal'nyi i funktsional'nyi podkhody. Moscow, 2012. Pp. 382-476.]

Суник, 1947 - Суник О.П. Очерки по синтаксису тунгусо-маньчжурских языков. Посессивный строй предложения. Л., 1947. [Sunik O.P. Ocherki po sintaksisu tunguso-man'chzhurskikh yazykov. Posessivnyi stroi predlozheniya [Essays on the syntax of the Tungus-Manchu languages. Possessive sentence structure]. Leningrad, 1947.]

Тексты, 2018 - Тексты // Малые языки Сибири: наше культурное наследие. Выложила Е.Л. Клячко. URL: http://minlang.srcc.msu.ru/textspage [Texts. Malye yazyki Sibiri: nashi kul'turnoe nasledie. E.L. Klyachko (ed.). URL: http://minlang. srcc.msu.ru/textspage] 
Шахматов, 1952 - Из трудов А.А. Шахматова по современному русскому языку: учение о частях речи. М., 1952. [Shakhmatov A.A. Iz trudov A.A. Shakhmatova po sovremennomu russkomu yazyku: uchenie o chastyakh rechi [From the studies by A.A. Shakhmatov on Modern Russian: Doctrine on parts of speech]. Moscow, 1952.]

Abney, 1987 - Abney S. The English noun phrase in its sentential aspect. $\mathrm{PhD}$ diss. MIT, 1987.

Baker, 2011 - Baker M.C. Degrees of nominalizations: clause-like constituents in Sakha. Lingua. 2011. Vol. 121. No 7. Pp. 1164-1193.

Chafe, 1994 - Chafe W. Discourse, consciousness and time: The flow of conscious experience in speaking and writing. Chicago, 1994.

Cinque, 2016 - Cinque G. On the double-headed analysis of "headless" relative clauses. Ms. Università Ca'Foscari Venezia, 2016. URL: http://ling.auf.net/ lingbuzz/003224.

Dékány, Tánczos, 2017 - Dékány É., Tánczos O. The structure of Udmurt past participles. Paper presented at BLINC-2, June 2017, Budapest.

Doron, Reintges, 2005 - Doron E., Reintges Ch. On the syntax of participial modifiers. Ms. The Hebrew University of Jerusalem, Leiden University, 2005.

Göksel, 2013 - Göksel A. Flexible word order and anchors of the clause. SOAS Studies in Linguistics. 2013. Vol. 16. Pp. 2-25.

Grenoble, 2012 - Grenoble L.A. Areal typology and semantic change. Vestnik TGPU. 2012. Vol. 116. No 1. P. 101-105.

Csató, Muzappar, 2010 - Csató É.Á., Muzappar U.A. On Ouigur reative clauses. Turkic languages. 2010. No 14. Pp. 69-93.

Kayne, 1994 - Kayne R. The antisymmetry of syntax. Cambridge, 1994.

Kim, 2004 - Kim M.-J. Three Types of Kes-Constructions. Harward Studies in Korean Linguistics 10. Lee I.-H. et al. (eds.). Cambridge, 2004. Pp. 479-492.

Nedjalkov, 1997 - Nedjalkov I. Evenki. London, New York, 1997.

Polinsky, 2015 - Polinsky M. Tsez syntax. Ms. Harward University, 2015.

Volkova, 2017 - Volkova A. Syntactic structure of participial clauses in meadow mari. Linguistics WP BRP 54/LNG/2017. URL: https://wp.hse.ru/data/2017/04/11/11 68369365/54LNG2017.pdf.

Shagal, 2017 - Shagal K. Towards a typology of participles. PhD dis. University of Helsinki, 2017.

\section{Статья поступила в редакцию 18.05.2018}

The article was received on 18.05.2018

Рудницкая Елена Леонидовна - доктор филологических наук; ведущий научный сотрудник отдела языков народов Азии и Африки, Институт востоковедения РАН, г. Москва

Rudnitskaya Elena L. - Dr. Phil. Hab.; leading researcher at the Department of Asian and African Languages, Institute of Oriental Studies, RAS, Moscow

E-mail: erudnitskaya@gmail.com 


\section{A.H. Сахарусов}

Военный университет Министерства обороны РФ, 123001 г. Москва, Российская Федерация

\section{К вопросу \\ об особенностях функционирования швабского территориального диалекта в официально-деловой сфере (анализ разговоров во время радиодебатов в г. Штутгарт)}

В статье исследуются особенности речевой коммуникации носителей швабского территориального диалекта во время радиодебатов. Дебаты проходили в рамках передачи на радиостанции SWR города Штутгарт. Исследование проведено методом дискурсного анализа корпуса текстов, полученных непосредственным наблюдением.

В результате исследования особенностей употребления швабского территориального диалекта в сфере образования выделены нехарактерные общественные функции этой формы существования языка. К таковым автор отнес выражение эмоций, привлечение внимания и регулирование коммуникативной дистанции.

Результаты исследования могут представлять интерес для социолингвистики как описание функционирования территориального диалекта в обществе.

Ключевые слова: диалекты, функционирование диалектов, социофункциональная модель диалекта, теория социально-групповых диалектов. 


\section{A.N. Saharusov}

Military University of the Ministry of Defense of the Russian Federation, Moscow, 123001, Russian Federation

\section{On functional characteristics of Swabian regional dialect in the official area}

This article investigates some functions of regional dialects in modern society. In the focus of this study is the description of features of the native speaker's speech in official situations. The aim of the study is to describe some features of speech communication among native speakers in Swabia in official situations. The research has been carried out by the method of discourse analysis of directly observed texts. As a result of the study of some features of Swabian regional dialect implementation in official area new social functions of regional dialects have been discovered. They include expression of emotions, drawing attention and regulation of the communicative distance. The results of the study may be useful for sociolinguistics as a description of the territorial dialect functioning in the society.

Key words: dialect, functioning of dialects, the social-groups-dialects theory, sociofunctional model of a dialect.

В эпоху глобализации расширение контактного пространства современного социума меняет правила языкового поведения индивидов по всему миру. Описываемые изменения затронули и правила использования в речи территориальных диалектов. Ранее в результате исследования их функциональных свойств нас заинтересовал тот факт, что современные территориальные диалекты используются в нетрадиционных для них сферах общения [Сахарусов, 2014]. Наибольший интерес для нас представляет языковая ситуация в современной Германии. Во-первых, потому, что диалект в этой стране является не просто языковым средством, но составляет неотъемлемую часть языкового портрета ее гражданина [Ammon, 1999, S. 77]. Во-вторых, большая социальная мобильность населения современной Германии позволяет провести исследование всех социальных слоев. И в-третьих, высокий уровень образования немцев гарантирует знание всеми респондентами стандартного языка. 
На настоящий момент существует большое количество исследований, описывающих функции территориальных диалектов в немецком обществе. Например, Н.И. Филичева относит к функциональной области территориального диалекта общение между близкими людьми [Филичева, 1983, с. 83]. Многие исследователи соотносят использование диалекта с низким социальным статусом и территориальной принадлежностью говорящего на нем [Баранникова, 1968, с. 172; Goosens, 1977, p. 65; Бондалетов, 1987, с. 54].

Однако анализ немецкоязычных публикаций, как современных, так и давно известных, показывает, что немцы могут использовать родной диалект и в официальном общении. Например, в своей статье немецкий журналист Й. Людвиг (Joachim Ludwig) рассказывает о новостях города Майнц на местном диалекте [Ludwig, 2004, S. 13]. В.Б. Меркурьева отмечает, что диалект в немецких средствах массовой информации встречается часто, в особенности, если тематика репортажей пересекается с жизнью местного населения [Меркурьева, 2010, с. 104]. Диалект проникает также и в сферу науки. Например, известна статья немецкого лингвиста X. Хекманна, в которой автор для более точного выражения своих мыслей использует диалект [Heckmann, 1986, S. 67]. В.Б. Меркурьева отмечает диалектные вкрапления в речи многих немецких политиков, писателей и общественных деятелей: К. Аденауэра, Г. Коля, Л. Фейхтвангера, Г. Грасса и др. [Меркурьева, 2010, с. 104].

Проникновению диалекта в официальные сферы общения была посвящена научная дискуссия в телепередаче «Nachtcafe-Dialekt» (телеканал «Südwestrundfunk», регион Баден-Вюртемберг) от 11 июня 2004 г. [Nachtcafe-Dialekt, 2004]. В ходе дискуссии ее участники доказали, что даже в официальных областях в некоторых случаях коммуниканты активно переходят на диалект, приведены многочисленные примеры. Вместе с тем, о причинах такого переключения участники дискуссии речь почти не ведут [Там же, 2004].

В языкознании проблеме кратковременного переключения языкового кода посвящены исследования Я.-П. Блума, Дж.П. Гамперца, Ш. Поплак, П. Ауэра, К. Майерс-Скоттон, Р. Аппеля, Л. Милрой, Х. Баназ, О.С. Родионовой [Bloom, 1972; Gumperz, 1982; Appel, 1987; Poplack, 1988; Auer, 1998; Myers-Scotton, 1993; Milroy, 1995; Banaz, 2002; Bussmann, 2002; Родионова, Абрамова, 2015]. Важно отметить, что О.С. Родионова, Х. Буссман, П. Ауэр отмечают возможность переключения языкового кода как в двуязычных обществах, так и в одноязычных. О.С. Родионова считает, что переключение происходит в случае владения коммуникантами разными формами существования языка [Родионова, Абрамова, 2015, с. 3]. 
Проанализировав указанные выше работы, можно сделать вывод о том, что в современном языкознании существует три основных подхода к объяснению причин переключению языкового кода. Первый социолингвистический подход, предложенный Я.-П. Блумом. Он состоит в объяснении феномена перехода на альтернативный код сменой коммуникативных ситуаций (ситуативный аспект) или сменой темы беседы (метафорический аспект) [Bloom, 1972].

Дж. Гамперц сформулировал интеракциональную теорию, которая объясняет переключение языкового кода невербальной коммуникацией говорящих, а также котекстуализацией их речи [Gumperz, 1982].

Р. Аппель в рамках своей теории выявил социальные функции переключения языкового кода, включающие в себя помимо прочих экспрессивную и фатическую [Appel, 1987].

Таким образом, проблема описания металингвистической функции переключения языкового кода в языкознании не нова. О.С. Родионова и Н.В. Абрамова считают, что и в современном обществе эта функция используется довольно широко. По их мнению, переключение языкового кода отражает социальное отношение и выражает соответствующие права и обязанности коммуникантов [Родионова, Абрамова, 2015, с. 5].

В рамках данной статьи рассматривается реализация коммуникативных функций переключения языкового кода стандартный немецкий язык - швабский территориальный диалект в условиях реальной коммуникации.

Говоря о швабском территориальном диалекте, необходимо отметить, что исследования его современного состояния показывают неоднородность этой формы существования языка. Так, В.Б. Меркурьева говорит о том, что совместное использование литературного языка и швабского территориального диалекта привело к появлению так называемого швабского диалекта образованных людей (Honoratiorenschwäbisch), представляющего собой приближенную к литературному стандарту диалектно окрашенную форму существования языка [Меркурьева, 2011].

В определении швабского диалекта образованных людей (Honoratiorenschwäbisch) мы согласны с Н.Г. Помазан и В.Б. Меркурьевой, относящих к основному его признаку сглаживание или полное отсутствие лексических и грамматических признаков диалекта [Помазан, 1994, c. 114; Меркурьева, 2005, с. 120]. Таким образом, основным признаком Honoratiorenschwäbisch мы считаем отличия от стандарта в области фонетики.

Подобное определение понятия швабского диалекта образованных людей приводят многие исследователи немецкой языковой системы: 
Л.Б. Копчук, Н.Г. Помазан, В.Б. Меркурьева, известный немецкий драматург Себастиан Блау и другие [Помазан, 1994, с. 114; Post, 2001, 2010; Копчук, 2002, с. 105; Daibler, 2013, p. 5; Blau, 2014, S. 3].

Выделяя в языковом континууме интересующей нас области швабский территориальный диалект и швабский диалект образованных лиц, необходимо соотносить личностное восприятие этих языковых форм обывателями. Понятно, что сельский житель воспринимает Honoratiorenschwäbisch сильно приближенным к литературной норме, в то время как житель столицы Федеральной земли - как отклонение от нее.

С целью исключить описанную разницу в определении термина «диалект» респондентами мы выбрали для исследования диалоги лиц с высоким, средним и низким социальным статусом, проживающих в г. Штутгарт.

Ранее, исследовав аудиозаписи занятий в гимназии столицы Федеральной Земли Баден-Вюртемберг, мы отметили возникающие в речи коммуникантов диалектные вкрапления. Причем на диалекте разговаривают не только студенты, но и преподаватели [Сахарусов, 2017, с. 12]. $\mathrm{B}$ качестве функций, которые реализуют собеседники с помощью диалекта, мы выделили функции привлечения внимания, установления контакта и выражения эмоций [Там же].

Следующей коммуникативной ситуацией мы выбрали общение в рамках многодневного диспута, проведенного на радиостанции SWR (Südwestrundfunk) на тему реконструкции вокзала г. Штутгарт. Языковой материал представлен нам Институтом немецкого языка (Institut für Deutsche Sprache, IDS) и представляет собой аудиозаписи разговоров из базы данных разговорного немецкого языка (Datenbank für Gesprochenes Deutsch, DGD). К аудиофайлам приложены их расшифровки. Все аудиозаписи имеют длительность 4 часа 20 минут; общий размер, общее количество слов в файле расшифровки - 78800 .

Необходимо отметить, что предоставленные нам материалы обрабатывались непосредственно носителями швабского территориального диалекта - Институтом немецкого языка, расположенном в г. Мангейм. Этот факт позволяет нам утверждать достоверность представленных сведений, в частности, диалектных отличий в области фонетики. Вместе с тем, существует вероятность ошибочного распознавания того или иного диалектного отличия. Эта ошибка устранена размером выборки - в случае с аудиодебатами в качестве диалектных отличий выбраны фонетические отклонения, встречающиеся в речи разных людей, многократно, на протяжении четырех часов аудиозаписей. Таким образом, вероятность такой ошибки ничтожно мала. Обсудив вопросы, связанные с теоретическими аспектами исследования, перейдем к описанию 
социальных аспектов рассматриваемой коммуникативной ситуации и анализу языкового материала.

В аудиодебатах принимали участие: Макс Ост (Max Ost), журналист SWR, ведущий программы, мужчина 40 лет; Генрих Гайслер (Heinrich Geißler), министр по делам семьи ФРГ, философ, юрист, 75 лет; Ханнес Рокенбаух (Hannes Rockenbauch), политолог, мужчина, 50 лет; Гарольд Кирхнер (Harald Kirchner), журналист SWR, мужчина, 50 лет; а также эксперты, противники проекта нового вокзала и их оппоненты, всего 34 участника. Мы относим ведущего радиопередачи, министра по делам семьи ФРГ и экспертов к представителям высокого социального статуca, а гостей в студии - к комммуникантам со сниженным социальным статусом в рамках данной коммуникативной ситуации.

Прослушав аудиозаписи, можно сразу сделать вывод о том, что участники дискуссии активно используют в своей речи диалект. Далее мы приведем несколько примеров. Для удобства восприятия диалектные вкрапления в речи коммуникантов выделены полужирным шрифтом.

В первом примере Макс Ост приветствует участников дебатов: Guten Morgen, meine Damen und Herren, willkommen im Stuttgarter Rathaus! Willkommen zur siebten Runde der Stuttgart einundzwanzig Schlichtung. 'Доброе утро, дамы и господа! Добро пожаловать на седьмой раунд дебатов в Ратуше города Штутгарт!' [DGD_FOLK_64_1: 0003].

Ведущий в своем обращении применяет формулы вежливости и придерживается стандартного языка. Г. Гайслер, обращаясь к зрителям, также использует формулы вежливости. Использование диалекта здесь исключено правилами хорошего тона: So, meine sehr verehrten Damen und Herren... 'Итак, глубокоуважаемые дамы и господа!' [DGD_FOLK_64_1: 0005].

Дебаты начинаются, и Г. Гайслер, стараясь установить контакт со своими гостями, использует в речи незначительные диалектные вкрапления. Например, представляя своих собеседников, министр говорит: Vorstandsmitglied technischer Vorstand ist der nun inzwischen der ganzen Republik bekannte Diplomingenieur Volker Kefer. Die Frau Tanja Gönner is ebenfalls bundesweit bekannt, die Ministerin. Jetz muss ich genau sehn, jedenfalls is sie die Umwelt und Verkehrsministerin. Is des richtig? Verbraucherschutz is auch noch dabei? 'Представитель технического обеспечения - известный всей стране дипломированный инженер Волькер Кефер. Фрау Таня Гённер также известна всей стране, министр. Теперь я должен уточнить, одновременно по делам защиты окружающей среды и транспорта? Правильно? Права потребителей тоже входят в вашу компетенцию?’ [DGD_FOLK_64_1: 0057]. 
В ответ на диалектную речь господина Гайслера его собеседники отвечают на стандартном немецком языке. Например, одна из его собеседников, Таня Гённер, уточняет область своей компетенции: Ja, und für Naturschutz 'Да, и по защите окружающей среды' [DGD_FOLK_64_1: 0132]. Второй собеседник, Карл Арнольди (Karl Arnoldi), также уточняет: Ich vertrete den Verkehrsclub Deutschlands ' Я представляю транспортные компании ФРГ’ [DGD_FOLK_64_1: 0163]. Мы считаем, что подобное языковое поведение продиктовано официальным статусом теледебатов и высокой степенью волевого контроля речи их участников.

По мере развития дебатов собеседник господина Гайслера, Волькер Кеффер, отвечает на его вопрос, при этом волнуется и говорит, что не может точно ответить на него, т.к. не является специалистом. В его речи появляются диалектные вкрапления: Der Kosten für eine dingliche Sicherung nach einem Münchener Sellner (Zellner) Verfahren, Herr Geißler, da muss ich ganz offen gestehn - das kann ich Ihnen auch nich so wirklich erklarn, weil ich kein Fachmann bin. Dafür aber daraus entstehn nochmal zweiunzwanzich Millionen Einsparungen. 'Средства для вещественного страхования должны быть предусмотрены Мюнхенским казначейством, господин Гайслер, однако я должен заявить, что не могу пояснить этот факт точно, поскольку не являюсь специалистом в этой области. Отсюда возникают еще двадцать два миллиона экономии.' [DGD_FOLK_64_1: 0057].

Генрих Гайслер старается прекратить дискуссию на эту тему и обращается к собеседнику на диалекте: Dann lass mer's Weg. 'Тогда оставим это!' [DGD FOLK_64_1:0076]. Заметив, что господин Кеффер не отреагировал на его требование, он раздраженно говорит ему: Lassen Sie es dann weg! 'Опустите тогда это!', обращаясь к собеседнику на стандартном языке и нарочно проговаривая каждую букву [DGD_FOLK_64_1: 0077]. Крайнюю степень недовольства Генрих Гайслер выражает на чистом диалекте: Vielleicht, kö_mer diese Detaildarstellung, niçћwähr, vielleicht einfach weglassa! 'Может быть, мы можем просто опустить представление данных, не так ли?!' [DGDFOLK_64_1: 0078]. Эмоциональное возбуждение министра выдает интонация и вводная фраза niçћ währ? 'не так ли?', также диалектно окрашенная.

По мере усиления эмоциональной составляющей диспута Г. Гайслер все чаще использует диалект для выражения своего стремления поддержать собеседников и показать им свое расположение. Отвечая на вопрос Гайслера, заданный на диалекте, его коллега Генрих Рокенбаух (Henrich Rokenbauch) также использует диалект. 
Он говорит: Würd' isch eigentliçh empfehlen, weil des is... is onsr Problem gewesen. Ich hab' des auch genau formuliert und ich hab' des noch mal wiederholt und des is, glaub ich, der richtige Weg, denn wir hier jetzt was... 'Я бы Вам посоветовал,... так как...это... было нашей проблемой. Я это точно сформулировал и, я еще раз повторю - это был правильный путь, так как мы здесь сейчас...' [DGD_FOLK_64_1: 0542]. Его собеседник перебивает: Ich versteh's noch nich ganz, wie des funktioniern soll. Wenn wir ham de offene Frage, zum Beispiel des Tal Längsschnittes, isch erklär kurz für die Zuschauer, worum's uns da geht... 'Я не понимаю точно, как это должно работать. Если бы вопрос был открыт, например, по разрезу долины - я разъясню слушателям, о чем идет речь' [DGD_FOLK_64_1: 0551]. На наш взгляд, использование диалекта в этой ситуации свидетельствует о снижении степени эмоционально-волевого контроля собеседника и готовности его к диалогу.

Активно с помощью диалекта во время теледебатов выражаются негативные эмоции. Например, в то время, когда Г. Гайслер пытается объяснить зрителям смысл сокращения Bast (Betriebliche Aufgabenstellung 'технические требования'), один из зрителей выкрикивает из зала диалектно окрашенное слово Baschtard (груб. 'ублюдок'). Диалектная окраска делает это слово еще резче и господин Гайслер вынужден приложить много сил, чтобы держать себя в руках.

Пример: DGD_FOLK_00068_1:

0370 [Heinrich Geißler] Bast noch mal also ich muss hier einfach im Interesse der Zuschauer sagen - des is eine saudumme Abkürzung für ... 'БАСТ, я должен еще раз пояснить, ввиду интереса слушателей. Это дурацкое сокращение от (слова)...'

0372 [Gast] Ich find' das Ba hinten wegen Baschtard! 'Я считаю, что БА - это что-то вроде ублюдка!'.

0374 [Heinrich Geißler] Ah! Wie...wie... wie... noch mal?! 'Ax! Как... Как... Как... еще раз?!'.

Интересно, что после этого случая вводная конструкция nicht wahr? 'не так ли?', выражающая задумчивость Генриха Гайслера, приобретает ярко выраженный диалектный оттенок.

Пример: DGD_FOLK_00068_1:

0384 [Heinrich Geißler] Wollt ja nur noch klarstellen, niçh währ, was dieses Abkürzungsmonster bedeutet. Deshâ_mêr jetz gehört, Herr Keffer, bidde schön! 'Мы только хотели пояснить, не правда ли, что обозначает это чертово сокращение. Это мы сейчас услышали, господин Кефер, пожалуйста!'.

Из приведенных примеров видно, что диалект в официально-деловой сфере общения может использоваться представителями как высокого, 
так и низкого социального статуса в ситуациях, связанных со снижением степени эмоционально-волевого контроля, а также для сокращения коммуникативной дистанции и привлечения внимания других коммуникантов.

Для проверки этих предположений, сделанных на основе анализа отдельных фрагментов текстов, мы провели статистический анализ имеющегося языкового материала методом анализа корпуса текстов. Весь корпус был разбит нами на диалоги, которые проанализированы по двум параметрам. Первый параметр - отношение обращений коммуникантов друг к другу с диалектными вкраплениями к общему количеству таких обращений в рамках диалога. Второй параметр - реализация коммуникативных интенции участников диалогов.

Для иллюстрации порядка анализа корпуса текстов приведем пример работы над его частью. На рис. 1 показана расшифровка части аудиофайла [DGD_FOLK_00068_1].

\begin{tabular}{|c|c|l|}
\hline 0587 & HG $\rightarrow$ XM & Bitte Land... \\
\hline 0588 & PC $\rightarrow$ HG & Land hat der Verrat... \\
\hline 0589 & HG $\rightarrow$ PC & Ja, okay, gut also die Land... das Land hat die Verantwortung \\
\hline 0591 & HG $\rightarrow$ PC & Des isch klar nicht! \\
\hline 0592 & $\mathbf{X M ~} \rightarrow$ HG & Immer wieder des Land! \\
\hline 0593 & PC $\rightarrow$ HG & $\begin{array}{l}\text { Richtiçћ eine irgend ein Regierungspräsidium eine Ministerin } \\
\text { hat immer eine größere Verantwortung, nich wahr, als ein Bür- } \\
\text { germeister oder Oberbürgermeister, oder ein Bahnvorstand wird } \\
\text { wahrscheinlich bestritten werden, aber des is meine Auffassung } \\
\text { nich so, also es mach mehr doch mal! }\end{array}$ \\
\hline
\end{tabular}

Рис. 1. Расшифровка аудиозаписи радиодебатов

В этом примере показаны диалоги Г. Гайслера и П. Конради, а также Г. Гайслера со зрителями в зале. Всего в этом отрывке г-н Гайслер обращается к П. Конради три раза, при этом один раз - с использованием диалектных вкраплений. П. Конради обращается к Г. Гайслеру в этом отрывке два раза. Диалект при этом использует в одном обращении. Г. Гайслер обращается к зрителям в зале один раз, при этом не допускает отклонения от языковой нормы. Зрители в единственной реплике, обращенной к министру, допускают переключение на диалект. Данные, полученные при первичном анализе речи коммуникантов, заносились таблицу, показывающую отношение обращений с диалектными вкраплениями к общему количеству обращений. Для примера покажем таблицу, составленную для приведенного на рис. 1 отрывка. 
Таблища 1

Отношение обращений с диалектными вкраплениями к общему количеству обращений (для отрывка корпуса)

\begin{tabular}{|c|c|c|c|}
\hline Адресант & $\begin{array}{l}\text { Генрих } \\
\text { Гайслер }\end{array}$ & $\begin{array}{l}\text { Петер } \\
\text { Конради }\end{array}$ & $\begin{array}{c}\text { Другие } \\
\text { коммуниканты }\end{array}$ \\
\hline \multirow{2}{*}{ Генрих Гайслер } & & 3 & 1 \\
\hline & & 1 & 0 \\
\hline \multirow{2}{*}{ Петер Конради } & 2 & & - \\
\hline & 1 & & - \\
\hline \multirow{2}{*}{$\begin{array}{l}\text { Другие } \\
\text { коммуниканты }\end{array}$} & 1 & - & \\
\hline & 1 & - & \\
\hline \multicolumn{2}{|c|}{$\begin{array}{l}\text { Общее количество } \\
\text { обращений }\end{array}$} & \multicolumn{2}{|c|}{$\begin{array}{l}\text { Обращения с диалектными } \\
\text { вкраплениями }\end{array}$} \\
\hline
\end{tabular}

С целью выявления функций переключения языкового кода мы разбили весь корпус на диалоги, в которых выявили адресанта и адресата сообщения. Из общего контекста мы выявили те коммуникативные задачи, которые, на наш взгляд, должны были выполнять респонденты в данном обращении.

Например, в обращениях к П. Конради Г. Гайслер раздражен и демонстрирует это повышением интонации голоса и использованием диалектно окрашенного указательного местоимения des (das - 'это').

Пример DGD_FOLK_00068_1:

0591 [Heinrich Geißler] Des isch klar nicht! 'Конечно, это не так!'.

Таким образом, в приведенном отрывке корпуса текстов Г. Гайслер в диалоге с П. Конради реализует эмоционально-экспрессивную функцию один раз переключением языкового кода со стандартного языка на диалект и один раз с использованием других средств (повышение интонации голоса).

Полученные данные были сведены в табл. 2, отражающую частоту реализации участниками радиодебатов интересующих нас коммуникативных функций. К сожалению, объем статьи не позволяет проанализировать все рассмотренные нами диалоги. Результаты исследования всего корпуса текстов отражены в табл. 2, 3. 
Rhema. Рема. 2018. № 3

$\frac{\sqrt{0}}{3}$
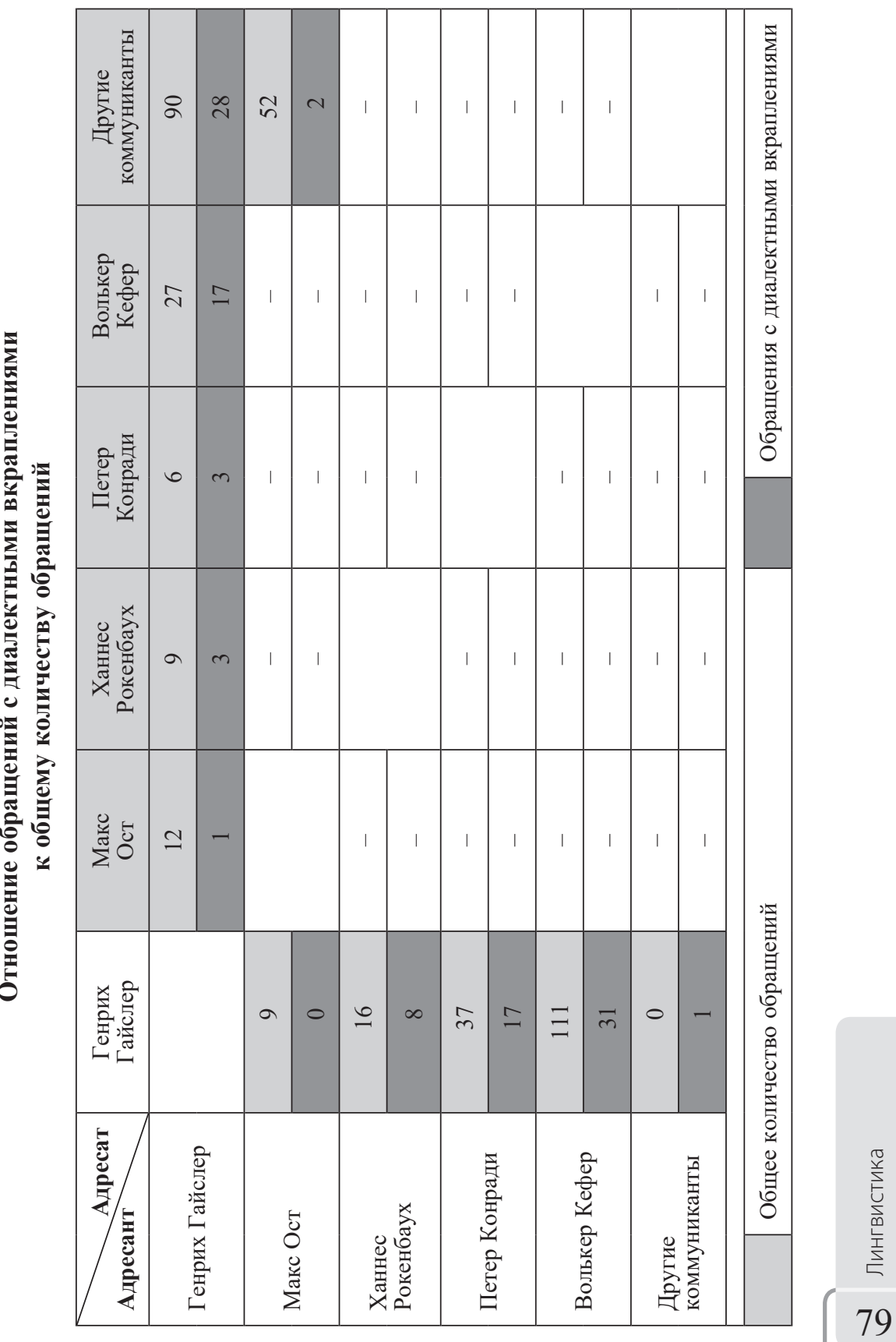
Из табл. 2 видно, что доля обращений с использованием диалекта в общем количестве обращений участников дебатов довольно велика. Причем количество обращений тем больше, чем больше в коммуникант участвует в дебатах. Наиболее активно диалект для привлечения внимания используют Г. Гайслер - в общении с гостями в студии, М. Ост в общении с гостями в студии, П. Конради и В. Кефер в диалогах с Г. Гайслером и друг с другом.

На наш взгляд, такое языковое поведение определено именно неприемлемостью употребления диалекта в данной коммуникативной ситуации. Диалект, звучащий на официальном мероприятии, таким образом, является наиболее эффективным средством выделения краеугольных моментов дискуссии. Соответственно, наиболее часто диалект должен использоваться в ситуациях со сниженным уровнем эмоциональноволевого контроля коммуникантов.

Частоты реализации участниками диспута коммуникативных функций, выделенных нами в результате первичного анализа корпуса текстов, представлены в табл. 3. Данные этой таблицы показывают, что наиболее часто диалект для выражения эмоций используют Г. Гайслер в диалогах с В. Кефером и гостями в зале. В. Кефер также часто использует диалект в диалогах с Г. Гайслером. Кроме того, активно для выражения эмоций использует диалект Х. Рокенбаух. Оставшиеся активные участники дискуссии тоже эмоционально отвечают Генриху Гайслеру на диалекте.

Проанализировав данные табл. 3 и структуру самих диалогов, можно предположить, что диалект в речи коммуникантов проявляется во время обсуждения ошибок при планировании, финансировании и реализации проекта вокзала. Упрекая друг друга, стараясь оправдаться, собеседники в эмоциональном порыве перестают контролировать свое речевое поведение и переключаются на диалект. Обратное переключение происходит почти сразу - специально выдать свое волнение никто не хочет (см. пример DGD_FOLK_64_1:0057). Интересное наблюдение описано нами в примере DGD_FOLK_64_1:0384. Выведенный из себя грубой фразой, выкрикнутой из зала, г-н Гайслер обращается к В. Кеферу на диалекте. На наш взгляд, министр, используя диалект, передает собеседнику степень своего негодования.

Для проверки этих наблюдений мы воспользовались статистическим анализом. Методом анализа полученных статистических данных был выбран дисперсионный и корреляционный анализ сплошной выборки с использованием теста Мак-Немара и корреляционного многофакторного Т-критерия. Выбор метода анализа обусловлен относительно малой величиной выборки для использования методов параметрической 
Rhema. Рема. 2018. № 3
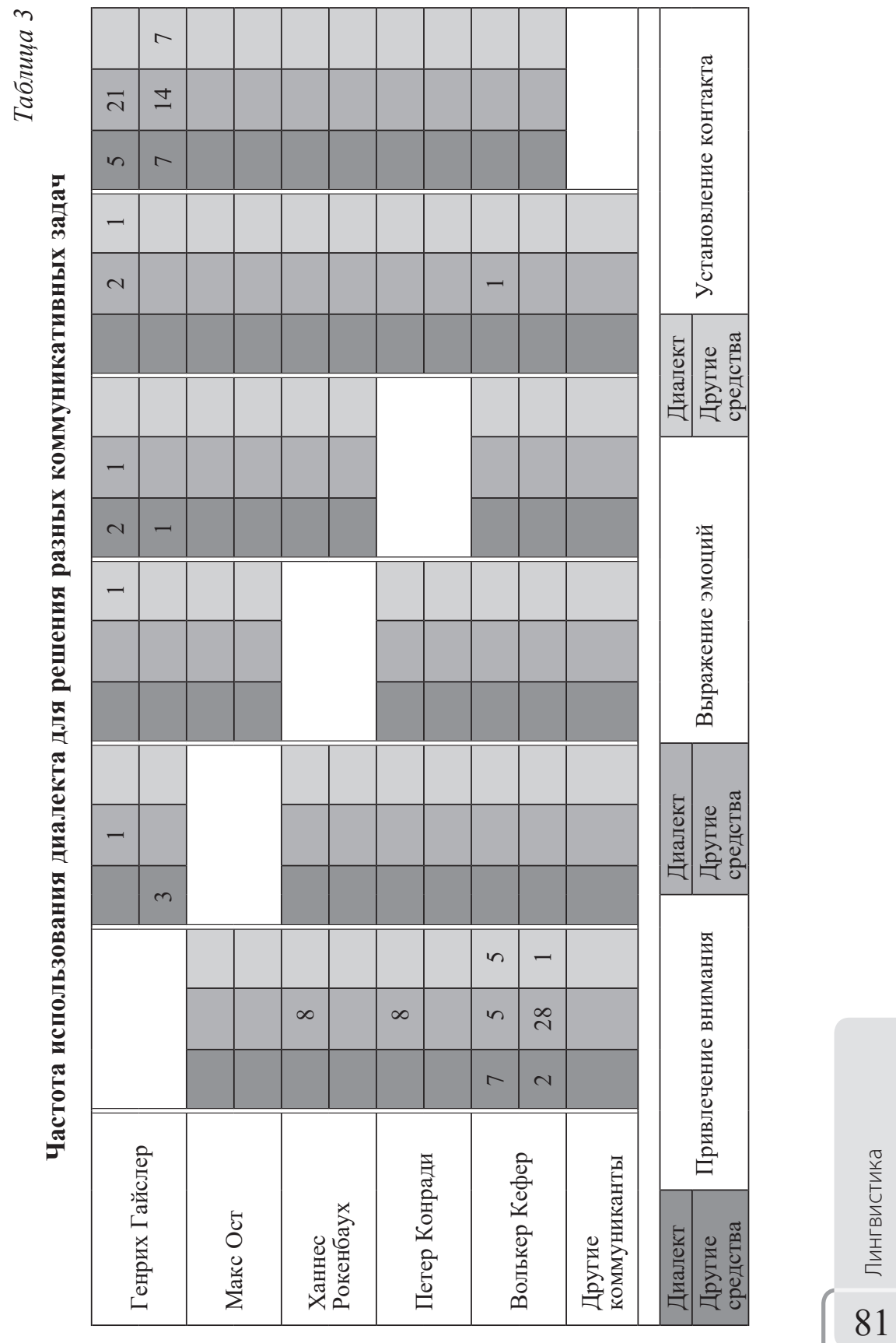
статистики и особенностями выборки. Все расчеты были выполнены в программе SPSS Statistics.

В соответствии с задачей исследования мы определяли в качестве зависимой переменной случаи использования диалекта. В качестве фактора выбора - коммуникативные задачи и индивидуальные речевые особенности коммуникантов. Исследование мы проводили, начиная с самого простого анализа - графического на основе диаграмм рассеяния. Для ее построения воспользуемся программой SPSS Statistics. Проверим влияние фактора индивидуальных речевых особенностей на использование респондентами диалекта. Отложим по оси абсцисс значение строки «Диалект» табл. 2, а по оси ординат - значение строки «Респондент». Диаграмма рассеяния в этом случае будет иметь вид, показанный на рис. 2.

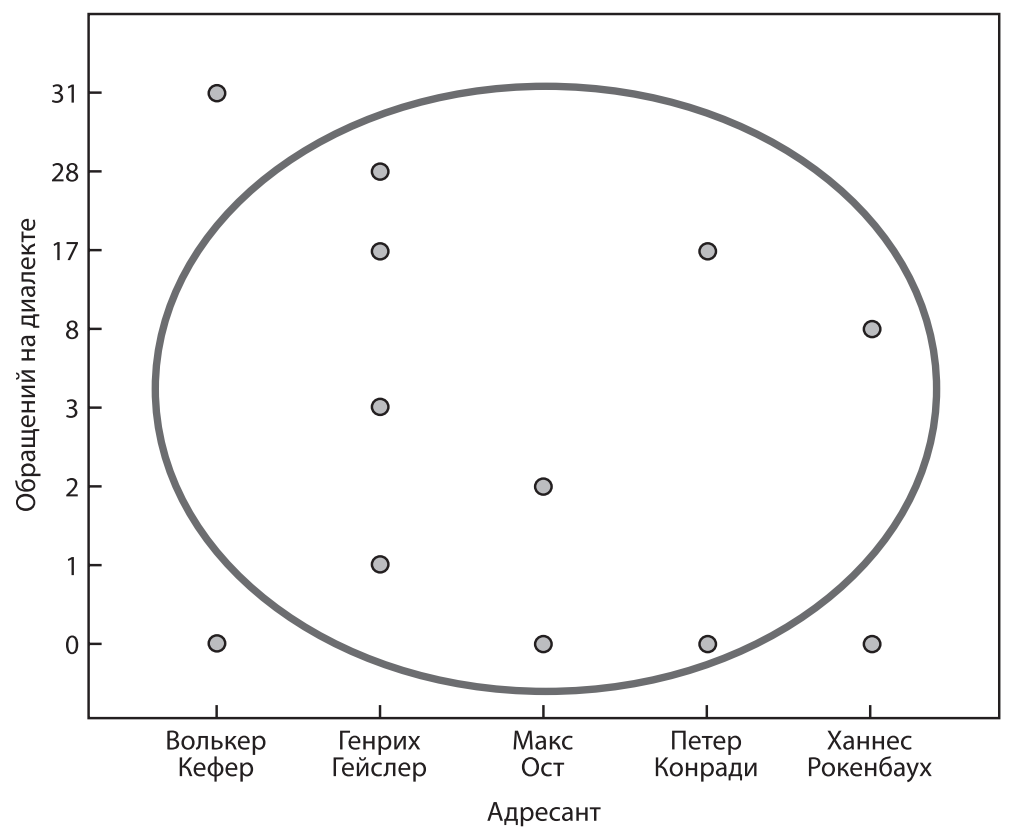

Рис. 2. Диаграмма рассеяния пары «Диалект - респондент»

Аппроксимирующая линия, построенная на диаграмме рассеяния, показывает отсутствие связи между использованием диалекта и индивидуальными особенностями респондентов. Для уточнения зависимости использования диалекта от исследуемого фактора проведем дисперсионный анализ. Для этого воспользуемся процедурой «ANOWA» 
(Analysis of Variance) программы SPSS Statistics. Для проведения анализа выберем уровень значимости $\alpha=0,05$, что соответствует точности 95\%. Результаты вычислений представлены в табл. 4.

\section{Таблица 4}

Дисперсионный анализ влияния на использование диалекта индивидуальных речевых особенностей коммуникантов

\begin{tabular}{|l|c|c|c|}
\hline & $\begin{array}{c}\text { Сумма } \\
\text { квадратов }\end{array}$ & Частота & $\begin{array}{c}\text { Коэффициент } \\
\text { значимости }\end{array}$ \\
\hline Между группами & 26,790 & 36,240 & 0,00 \\
\hline Внутри групп & 73,185 & & \\
\hline Итого & 99,975 & & \\
\hline
\end{tabular}

Из таблицы видно, что значение внутригрупповой дисперсии $(73,185)$ значительно превышает межгрупповую дисперсию $(26,790)$ [Гмурман, 2004, с. 123]. Таким образом, однофакторный дисперсионный анализ показывает отсутствие с большой степенью вероятности (коэффициент значимости $p<0,05)$ зависимости фактора индивидуальных особенностей коммуникантов на использование диалекта.

Далее проверим влияние на использование диалекта фактора коммуникативных интенций. Для этого проведем статистический анализ данных, представленных в табл. 3, с использованием программы SPSS Statistics. В качестве зависимой переменной выберем количество обращений с использованием диалекта, в качестве влияющих факторов коммуникативные задачи (выражение эмоций, привлечение внимания и стремление регулировать коммуникативную дистанцию). Результаты анализа представлены в табл. 4-7.

Таблица 5

Дисперсионный анализ влияния на использование диалекта фактора выражения эмоций

\begin{tabular}{|l|c|c|c|}
\hline & $\begin{array}{c}\text { Сумма } \\
\text { квадратов }\end{array}$ & Частота & $\begin{array}{c}\text { Коэффициент } \\
\text { значимости }\end{array}$ \\
\hline Между группами & 1922,2500 & 1025,200 & 0,003 \\
\hline Внутри групп & 3,7500 & & \\
\hline Итого & 1926,0000 & & \\
\hline
\end{tabular}


Таблица 6

Дисперсионный анализ влияния на использование диалекта фактора привлечения внимания

\begin{tabular}{|l|c|c|c|}
\hline & $\begin{array}{c}\text { Сумма } \\
\text { квадратов }\end{array}$ & Частота & $\begin{array}{c}\text { Коэффициент } \\
\text { значимости }\end{array}$ \\
\hline Между группами & 1751,223 & 28,725 & 0,005 \\
\hline Внутри групп & 172,735 & & \\
\hline Итого & 1923,958 & & \\
\hline
\end{tabular}

Таблица 7

Дисперсионный анализ влияния на использование диалекта фактора установления контакта

\begin{tabular}{|l|c|c|c|}
\hline & $\begin{array}{c}\text { Сумма } \\
\text { квадратов }\end{array}$ & Частота & $\begin{array}{c}\text { Коэффициент } \\
\text { значимости }\end{array}$ \\
\hline Между группами & 1651,223 & 28,758 & 0,007 \\
\hline Внутри групп & 272,735 & & \\
\hline Итого & 1923,958 & & \\
\hline
\end{tabular}

Из проведенных в табл. 5-7 данных можно сделать вывод о том, что фактор коммуникативных интенций влияет на использование диалекта респондентами в данной ситуации. Вероятность влияния фактора реализации намерения выразить эмоции $p=0,003$, фактора привлечения внимания $p=0,005$, фактора установления контакта $p=0,007$.

С целью выявления степени влияния факторов коммуникативных интенций на использование диалекта используем многофакторный T-критерий, проведенный с использованием программы SPSS Statistics (табл. 8).

Таблица 8

\section{Результаты анализа степени влияния} факторов коммуникативных интенций на использование диалекта

\begin{tabular}{|l|c|c|c|}
\hline \multicolumn{1}{|c|}{ Пары } & Количество & Корреляция & $\begin{array}{c}\text { Коэффициент } \\
\text { значимости }\end{array}$ \\
\hline $\begin{array}{l}\text { Обращения на диалекте } \\
\text { и эмоции }\end{array}$ & 25 & 0,930 & 0,001 \\
\hline $\begin{array}{l}\text { Обращения на диалекте } \\
\text { и внимание }\end{array}$ & 24 & 0,851 & 0,001 \\
\hline $\begin{array}{l}\text { Обращения на диалекте } \\
\text { и контакт }\end{array}$ & 24 & 0,816 & 0,002 \\
\hline
\end{tabular}


Данные анализа, представленные в табл. 8, показывают высокую степень влияния стремления реализации всех трех коммуникативных задач на использование диалекта. Для выражения эмоций к $=0,930$ при $p=0,01$, для привлечения внимания к $=0,851$ при $p=0,01$, для установления контакта к $=0,816$ при $p=0,02$.

Проанализировав случаи использования швабского территориального диалекта во время публичной дискуссии на радиостанции SWR (г. Штутгарт), можно сделать следующие выводы.

1. Диалект в официально-деловой сфере общения может использоваться представителями как высокого, так и низкого социального статуса в ситуациях, связанных со снижением степени эмоциональноволевого контроля.

2. В официально-деловой сфере швабский территориальный диалект может использоваться для реализации специфических коммуникативных задач.

3. Использование диалекта в том или ином случае находится в сложной зависимости от ситуативного фактора их употребления - в одной и той же ситуации может использоваться как диалект, так и другие формы существования языка.

4. Использование диалекта может помочь говорящему выразить свое отношение к предмету разговора. Подобным образом реализуется метаязыковая функция диалекта.

На наш взгляд, носители языка, переключаясь на диалект, руководствуются своими представлениями о возможности его использования для построения социально корректного высказывания в данной ситуации. Несоответствие ситуации используемой в ней форме существования языка и есть указание на желание реализации с помощью этого особой коммуникативной задачи.

\section{Библиографический список / References}

Баранникова, 1986 - Баранникова Л.И. О разграничении языка и диалекта // Язык и общество. М., 1986. C. 170-180. [Barannikova L.I. Separate concepts of a language and a dialect. Yazyk i obshchestvo. Moskow, 1968. Pp. 170-180.]

Бондалетов, 1987 - Бондалетов В.Д. Социальная лингвистика. М., 1987. [Bondaletov V.D. Social'naya lingvistika [Sociolinguistics]. Moskow, 1987.]

Гмурман, 2004 - Гмурман В.Е. Теория вероятности и математическая статистика: Учебное пособие для вузов. 10-е изд., стереотип. M., 2004. [Gmurman V.E. Teoriya veroyatnosti i matematicheskaya statistika [Probability theory and mathematical statistics]. Moskow, 2004.]

Меркурьева, 2005 - Меркурьева В.Б. Диалект и литературный язык в немецкоязычных драмах. Отношения комплементарности и изоморфизма: Дис. ... д-ра филол. наук. Иркутск, 2005. [Merkur'eva V.B. Dialekt i literaturnyj yazyk 
v nemeckoyazychnyh dramah. Otnosheniya komplementarnosti i izomorfizma [The use of dialect and standard language in German dramas. Analogy and antithese]. Dr. Phil. Hab. Dis. Irkutsk, 2005.]

Меркурьева, 2010 - Меркурьева В.Б. Штрихи к портрету личности носителя диалекта // Язык. Закономерности развития и функционирования: Сборник к юбилею Н.Н. Семенюк. М., 2010. С. 102-111. [Merkur'eva V.B. Description of dialect-based speaker's individual. Yazyk. Zakonomernosti razvitiya i funkcionirovaniya: Sbornik k yubileyu N.N. Semenyuk. Moskow, 2010. Pp. 102-111.]

Родионова, Абрамова, 2015 - Родионова О.В., Абрамова Н.В. Функции и типы переключения кода в немецком языке: теоретический аспект // Известия высших учебных заведений. Поволжский регион. Серия: Гуманитарные науки. 2015. № 1 (33). С. 139-148. [Rodionova O.V., Abramova N.V. Functions and types of code-switching in German language: Theoretical aspects. Izvestiya vysshih uchebnyh zavedenij. Povolzhskij region. Seriya: Gumanitarnye nauki. 2015. № 1 (33). Pp. 139-148.]

Сахарусов, 2014 - Сахарусов А.Н. О функционировании современных территориальных диалектов как формы существования языка // Вестник Череповецкого государственного университета. Череповец, 2014. № 4. С. 28-34. [Saharusov A.N. Functional characteristics of modern regional dialects. Vestnik Cherepoveckogo gosudarstvennogo universiteta. 2014. № 4. Pp. 28-34.]

Сахарусов, 2017 - Сахарусов А.Н. К вопросу об особенностях функционирования швабского территориального диалекта в сфере образования (анализ общения на занятиях в гимназии им. Ф. Листа города Мангейм) // Человек и общество. 2017. № 2 (3). С. 58-62. [Saharusov A.N. Functional characteristics of Swabian regional dialect in education (the analysis of discussion in classes in F. Liszt gymnasium in Mannheim). Chelovek i obshchestvo. 2017. № 2 (3). Pp. 58-62.]

Филичева, 1983 - Филичева Н.И. Диалектология современного немецкого языка: Учеб. пособие. М., 1983. [Filicheva N.I. Dialektologiya sovremennogo nemeckogo yazyka [Dialectology of the modern German]. Tutorial. Moscow, 1983.]

Ammon, 1999 - Ammon U. Nachbemerkung. Wird der Dialekt als Sprachbarriere wiederentdeckt? Muttersprache. 1999. № 1. Pp. 1 - 12.

Appel, 1987 - Appel R. Language contact and bilingualism. London, Baltimore, 1987.

Auer, 1998 - Auer P. Code-switching in conversation: language, interaction and identity. Bilingual Conversation Revisited. London, New York, 1998.

Banaz, 2002 - Banaz H. Bilingualismus und Code-switching bei der zweiten türkischen Generation in der Bundesrepublik Deutschland. Sprachverhaltung und Identitätsentwicklung. Banaz H. (Hrsg.). Essen, 2002.

Blom, Gumperz, 1972 - Bloom J.P., Gumperz J. Social meaning in linguistic structure: Code-switching in Norway. Directions in Sociolinguistics. The Ethnography of Communication. J.J. Gumperz, dell Hymes (eds.). New York, 1972. Pp. 407-434.

Bussmann, Hadumod, 2002 - Lexikon der Sprachwissenschaft. Bussmann H., Hadumod H. (Hrsg.). Stuttgart, 2002. Pp. 600-783.

Databank für gesprochenes Deutsch. 2014. URL: http://dgd.ids-mannheim.de:8080/ $\mathrm{dgd} /$ pragdb.dgd_extern.corpora?v_session_id=395BF01F044F3B925F8C687317192 26F\&v_doctype $=\mathrm{a} \& \mathrm{v} \_$corpus $=\mathrm{FOL} / \mathrm{L} 32-50$ (Date of the applications: 20.08 .2015 ).

Goossens, 1977 - Goosens J. Deutsche Dialektologie. Berlin, New York, 1977.

Gumperz, 1982 - Gumperz J. Discourse strategies. Cambridge, 1982. 
Heckmann, 1986 - Heckmann H. Irgendwie? Sprach-Störungen. Beiträge zur Sprachkritik. Tubingen, 1986.

Ludwig, 2004 - Ludwig J. Was für goldene Zeite. Mainzer Zeitung. Mainz, 2004. Samstag, 19. Juni. Pp. 2-7.

Milroy, 1995 - Milroy L. One speaker, two language; cross-disciplinary perspectives on codeswitching. New York, 1995.

Myers-Scotton, 1993 - Myers-Scotton C. Duelling Language. Grammatical Structure in Codeswitching. Oxford, 1993.

Nachtkafe-Dialekt. 2003. URL: www.swr.de/nachtcafe/rueckschau/sendungam-21-dialekt-charmaint-oder-scheusslich-lid=2249778/did=12712190/ nid=2249778/1yecrq7/index.html (Date of the applications: 20.08.2015).

Poplack, 1988 - Poplack S. Contrasting patterns of codeswitching in two communities Codeswitching. Anthropological and Sociolinguistic Perspectives. Berlin, 1988. Pp. 215-244.

Статья поступила в редакцию 7.09.2017

The article was received on 7.09.2017

Сахарусов Александр Николаевич - соискатель кафедры иностранных языков, Военный университет Министерства обороны РФ, г. Москва

Saharusov Alexander N. - degree applicant at the Department of Foreign Languages, Military University of the Ministry of Defense of the Russian Federation, Moscow

E-mail: alexander1286@bk.ru 


\section{С.Г. Татевосов}

Московский государственный университет им. М.В. Ломоносова, 119991 г. Москва, Российская Федерация;

Московский педагогический государственный университет, 119991 г. Москва, Российская Федерация

\section{Событийно-структурная морфология в ненецком языке}

В статье предлагается несколько обобщений о семантической интерпретации основ ненецкого глагола, различающихся типом вокалического ауслаута, и обосновывается анализ, согласно которому конечный гласный представляет собой морфему, выступающую морфологической этикеткой событийной структуры.

Ключевые слова: событийная структура, состояние, деятельность, свершение, ненецкий язык.

\footnotetext{
${ }^{1}$ Статья опирается на данные по малоземельскому говору тундрового диалекта ненецкого языка в варианте, представленном в п. Нельмин Нос (Ненецкий автономный округ), которые были собраны в ходе экспедиций Отделения теоретической и прикладной лингвистики филологического факультета МГУ в 2003-2005 гг. В экспедициях в разные годы участвовали Лев Блюменфельд, Екатерина Волович, Николай Воронцов, Филипп Дудчук, Павел Иосад, Наталья Зевахина, Денис Иванов, Михаил Иванов, Дарья Кавицкая, Екатерина Лютикова, Ирина Николаева, Анна Пазельская, Петр Староверов, Сергей Татевосов, Мария Цюрупа, Андрей Шлуинский, Елена Ханина, Ольга Ханина. Наблюдения и обобщения, изложенные здесь, стали возможны благодаря совместным усилиям всех участников экспедиции. Автор выражает искреннюю и бесконечно глубокую благодарность информантам-переводчикам А.Г. Апицыной, Е.Н. Ардеевой, М.И. Канюковой, В.П. Марюевой, К.П. Талеевой, Е.Н. Тайбарей и М.К. Тайбарею, общение с которыми навсегда останется источником надежды и оптимизма.

Исследование поддержано грантом РНФ № 16-18-02081, выполняемым в Московском государственном.университете им. М.В. Ломоносова.
} 


\section{S.G. Tatevosov}

Lomonosov Moscow State University, Moscow, 119991, Russian Federation

Moscow Pedagogical State University, Moscow, 119991, Russian Federation

\section{Event-structural morphology in Tundra Nenets ${ }^{2}$}

The paper explores semantic characteristics of verbal stems in Tundra Nenets that can take different stem-final vowels. I argue that the distribution of these vowels and interpretational effects they induce are best accounted for under an analysis that treats them as phonological signatures of different event structural configurations.

Key words: event structure, states, activities, accomplishments, Tundra Nenets.

\section{1. Вокалические ауслауты}

Цель этой статьи - изложить несколько неформальных обобщений о классе морфологических элементов в ненецком языке, которые выступают поверхностными этикетками определенных событийно-структурных конфигураций.

В общих чертах явление состоит в следующем. Ненецкие вокалические глагольные основы представлены несколькими типами, различающимися гласным ауслаута $-a, e, \varnothing$ или (y)o. Т. Салминен приводит следующие иллюстрации этих возможностей:

${ }^{2}$ The paper relies on the fieldwork data from the Mid Western variety of Tundra Nenets as spoken in the Nelmin Nos village. These data were collected in 2003-2005 in the fieldwork expeditions organized by the Department of Theoretical and Applied Linguistics, Faculty of Philology, Lomonosov Moscow State University. Observations and generalizations reported in this study would have not been possible without collective effort of the whole expedition team, which included Lev Blyumenfeld, Ekaterina Volovich, Nikolaj Vorontsov, Filipp Dudchuk, Pavel Iosad, Natalya Zevakhina, Denis Ivanov, Mikhail Ivanov, Darya Kavitskaya, Ekaterina Lyutikova, Irina Nikolaeva, Anna Pazelskaya, Peter Staroverov, Sergei Tatevosov, Maria Tsyurupa, Andrej Shluinsky, Elena Khanina, Olga Khanina. The author would like to express his endless gratitude to the native speakers of Tundra Nenets A.G. Apitsyna, E.N. Ardeeva, M.I. Kanyukova, K.P. Taleeva, E.N. Taibarei, M.K. Taibarei. Memories of meeting them will always be a source of optimism and hope.

The study has been supported by the Russian Science Foundation grant № 16-18-02081 at Lomonosov Moscow State University. 
(1) Основные ауслаутные типы основ [Salminen, 1998, p. 34-35]

а. хӑрва(сь) \{xørwa\} 'хотеть', хада(cb) \{xada\} 'убивать'

b. хӑдкэ(сь) \{xød'ke\} 'случаться', хане(сь) \{хanye\} 'охотиться', иле $(\mathrm{cb})$ \{yilye\} 'жить'

c. ненӑ(сь) \{nyenø\} 'сердиться', ядембӑ(сь) уadyempø 'быть горячим’, сэръя(сь) serÿø 'иметь привкус соли, быть солоноватым'

d. хонё(сь) \{хonyo\} 'спать', лӑбиеё(сь) 'быть слипшимся’

С точки зрения морфологического поведения основы распадаются на два больших класса - альтернирующие и неальтернирующие. Основы на а и $e$ всегда неальтернирующие, основы на (y)o всегда альтернирующие, для основ на ø доступны обе возможности.

Основные морфологические различия между альтернирующими и неальтернирующими основами проявляются в образовании так называемых общей финитной и специальной финитной основ. Общая и специальная финитная основы дополнительно распределены по группам словоизменительных форм, составляющих глагольную парадигму. Согласно описанию Т. Салминена, от общей финитной основы, среди прочего, образуется форма аориста субъектного спряжения, а от специальной финитной - аориста возвратного спряжения. Непосредственно от исходной основы образуется форма так называемого коннегатива, которая используется, в частности, при построении отрицательных финитных форм. Последние состоят из отрицательного вспомогательного глагола, принимающего лично-числовое согласование, и коннегатива лексического глагола.

В таблице 1 показаны основы с разным типом ауслаута и три диагностические формы от каждой: аорист третьего лица единственного числа субъектного спряжения (показатель Ø), аналогичный аорист возвратного спряжения (показатель $-q$ ) и коннегатив (показатель $-q$ ). Здесь и далее для различения альтернирующих и неальтернирующих основ на ø используются символы $\varnothing^{i}$ («альтернирующий ø) и $\varnothing^{\wedge}$ («неальтернирующий ø).

3 Здесь и далее мы придерживаемся следующих принципов представления материала. Отдельные ненецкие слова и морфемы приводятся в словарной форме по [Терещенко, 1965] и/или в записи Т. Салминена, заключенной в фигурные скобки, например, мадӑр (uь) \{madør\}. При необходимости дополнительно приводится фонетическая запись в квадратных скобках, которая опирается на описание фонетики исследуемого говора, предложенное в [Staroverov, Kavitskaya, 2010]. Примеры предложений состоят из четырех строк: фонетической записи, фонематической записи, которая следует принципам и описательным решениям Т. Салминена [Salminen, 1997, 1998], подстрочной поморфемной глоссы, 
Из таблицы 1 видно основное различие неальтернирующих и альтернирующих основ. У первых $\left(a, e, \varnothing^{\wedge}\right)$ общая финитная основа не совпадает со специальной финитной. У последних (ø ${ }^{i}$ и $(y) o$ ) они идентичны.

Основы на неальтернирующий гласный используют для образования общей финитной основы показатель -ø (редуцирующийся до -`), cp. формы аориста $3 \mathrm{SG}_{\mathrm{s}} \mathrm{s}^{4}$ xona- ${ }^{\circ}-\varnothing$, yilye- ${ }^{\circ}-\varnothing$ и yadø- ${ }^{\circ}-\varnothing$ из таблицы $1^{5}$. Специальная финитная основа, наблюдаемая в форме аориста 3SG.R, от основ на а и $e$ образуется с помощью суффикса -yø (с редукцией до $\left.-y^{o}\right)^{6}$, от основ на неальтернирующий -ø - «заменой конечного гласного на $i$-ø» (ø вновь редуцируется до $\left.{ }^{\circ}\right)$. Это дает соответственно хопе$y^{\circ}-q$, yilye- $y^{\circ}-q$ и yadi $-^{\circ}-q$.

Таблица 1

\section{Примеры глаголов с различным типом ауслаута}

\begin{tabular}{|c|c|c|c|c|}
\hline Основа & Тип & Аорист 3SG.S & Аорист 3SG.R & Conneg \\
\hline xona 'идти спать’ & $a$ & xona- ${ }^{\circ}-\varnothing[$ xona $]$ & xone $-y^{\circ}-q[$ xonej? $]$ & xona- $q$ [xona?] \\
\hline yilye 'жить' & $e$ & yilye- ${ }^{\circ}-\varnothing\left[\mathrm{jil}^{\mathrm{j}} \mathrm{e}\right]$ & yilye $-y^{\circ}-q\left[\mathrm{jil}^{\mathrm{j}} \mathrm{ej} \mathrm{j}\right]$ & yilye-q $\left[\mathrm{jil}^{\mathrm{j}} \mathrm{e}\right.$ ? $]$ \\
\hline yadø 'идти, ходить' & $\varnothing^{n}$ & yadø- ${ }^{\circ}-\varnothing[\operatorname{yad} \Lambda]$ & yadi- ${ }^{\circ}-q[$ jadi? $]$ & $y a d^{\circ}-q[\mathrm{jad} \mathrm{T}]$ \\
\hline nyеnø 'сердиться’ & $\varnothing^{i}$ & nyeni-Ø [ $\mathrm{n}^{\mathrm{j}}$ eni $]$ & nyeni- $q\left[\mathrm{n}^{\mathrm{j}} \mathrm{eni} \mathrm{i}\right]$ & nyenu- $q$ [n ${ }^{\mathrm{j}}$ enu?] \\
\hline xonyo 'спать' & $o$ & xoni-Ø [xoni] & $x o n i-q[$ xoni? $]$ & xonyu-q [xon'u?] \\
\hline
\end{tabular}

Альтернирующие основы производят «замену гласного на $i$ », и этот вариант используется и в качестве общей, и в качестве специальной финитной основы [Salminen, 1998, p. 532], ср. формы субъектного и возвратного спряжения пуеni-Ø и пуепi-q, а также хопі-Ø и хопi-q.

Основной факт, на который опирается наш дальнейший сюжет, состоит в том, что значительное количество основ допускается более чем с одним типом ауслаута. Несколько характерных пар из [Терещенко, 1965], где одна из основ представлена неальтернирующим вариантом, а вторая - альтернирующим, приводятся в (2)-(3):

${ }^{4}$ Условные сокращения: 1, 2, 3 - 1-е, 2-е, 3-е лицо; ABL - аблатив; АCC - аккузатив; CAUS - каузатив; DAT - датив; DUR - дуратив; FREQ - фреквентатив; FUT - будущее время; GEN - генитив; GFS - общая финитная основа; HAB - хабитуалис; INCH - инхоатив; IPFV имперфектив; ITER - итератив; LOC - локатив; м - непродуктивная деривация на -m; o объектное спряжение; PL - множественное число; PST - прошедшее время; R - возвратное спряжение; $\mathrm{s}$ - субъектное спряжение; SFS - специальная финитная основа; SG - единственное число.

5 Еще один способ образования общей финитной основы характерен для основ на согласный, не представленных в таблице 1: они присоединяют показатель - $y a$ \{nga\}.

${ }^{6}$ Кроме того, у основ на - $a$ наблюдается дополнительное чередование - переход $-a$ в $-e$, как у $x$ one- $y^{\circ}-q$. 
(2) Основы на $\boldsymbol{\theta}^{i}$ vs основы на $\boldsymbol{a}$

a. cыритӑ $(\mathrm{cb}) \quad$ siryitø\} 'быть заснеженным, быть покрытым снегом'

colpuma $(\mathrm{cb}) \quad$ siryita $\}$ 'наполнить, набить что-либо снегом'

b. сяклӑ(cb) $\quad\left\{\operatorname{syak}^{\circ} 1 \varnothing\right\} \quad$ 'быть прикушенным, зажатым, прищемленным'

сякла $(\mathrm{cb}) \quad\left\{\mathrm{syak}^{\circ} \mathrm{la}\right\} \quad$ 'впиться чем-либо во что-либо'

с. сындӑ $(c b) \quad\{$ sintø\} 'заниматься тем, что доставать продукты из продуктовой нарты' = = 'использовать запас'

сында $(\mathrm{cb}) \quad\{$ sinta $\} \quad$ 'отложить про запас'

(3) Основы на $(y) o$ vs основы на $\boldsymbol{a}$
а. хонё $(\mathrm{cb})$
\{xonyo $\quad$ 'спать'
хона $(\mathrm{cb})$
\{xona
'идти спать, ложиться спать'

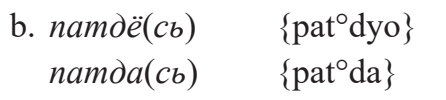
'быть в чехле (о ружье)'
'положить ружье в чехол, зачехлить'

В словаре обнаруживаются не только пары, но и тройки глаголов с неальтернирующим гласным и двумя альтернирующими:

(4) а. ваңзлӑ $(c b) \quad\left\{\right.$ wangk $\left.^{\circ} l \varnothing\right\}$

1) быть в берлоге (о медведе);

2) быть в снежной ямке (о куропатке);

b. ванцгла $(\mathrm{cb}) \quad\left\{\right.$ wangk $\left.^{\circ} \mathrm{la}\right\}$

1) залечь в берлогу (о медведе);

2) зарыться в снежную ямку (о куропатке).

с. вандлё $(\mathrm{cb}) \quad$ \{wangk ${ }^{\circ}$ lyo

1) лежать в берлоге (о медведе);

2) находиться в снежной ямке (о куропатке)

[Терещенко, 1965, с. 43].

Противопоставление нескольких «ауслаутных вариантов» систематически представлено не только у непроизводных глаголов, но и у продуктивных дериватов, таких, в частности, как каузатив или инхоатив [Татевосов, 2018].

Т. Салминен [Salminen, 1997, 1998], а вслед за ним и другие исследователи, например, И.А. Николаева [Nikolaeva, 2014], описывают варианты 
основ в терминах «альтернаций». Однако, как видно из (2)-(4), они проявляют систематические семантические различия и, очевидно, должны анализироваться как морфемы. Единственная известная нам работа, где эти различия охарактеризованы сколько-нибудь подробно, - статья А.Ю. Урманчиевой [Урманчиева, 2013, p. 755 et seq.] об образовании аориста в самодийских языках; некоторые наблюдения представлены также в [Гусев, 2010].

Таким образом, перед нами возникает ясная эмпирическая задача: построить более полную сумму обобщений о семантической интерпретации, привязанной к разным типам ауслаутов. В следующем разделе мы обсудим имеющиеся в этой области наработки, опираясь в основном на наблюдения и обобщения А.Ю. Урманчиевой.

\section{2. Альтернирующие основы и стативность}

А.Ю. Урманчиева предполагает, что альтернирующие глаголы на - ${ }^{i}$ и -(y)o образуют естественный семантический класс: все они представляют собой стативы. Она выделяет несколько частных их разновидностей, перечисленных в (5).

(5) а. Производные стативы, характеризующие инактивный субъект

(в частности - но не обязательно - стативы, производные

от переходных глаголов, объект которых становится субъектом производного статива): ngamdø- 'сесть' > > ngamdyo- 'сидеть'; pen- 'положить' > penуo- 'быть положенным'; xaye- 'оставить' > хауо- 'остаться, отстать'.

b. «Каритивные» отыменные глаголы, характеризующие субъект как лишенный чего-либо существенного: туасуø- 'быть бездомным'

с. «Одорфактивные» глаголы, характеризующие субъект как имеющий какой-либо специфический запах: ngøтсауø- 'пахнуть мясом'.

d. Имперфективные глаголы с суффиксом трø-.

е. Хабитуальные глаголы с суффиксом -syøtø.

f. Стативы, характеризующие активный субъект: $\mathrm{sed}^{\circ} \mathrm{ko}$-Vintr 'заниматься шитьем мелких предметов' // sedø-Vtr 'шить'

[Урманчиева, 2013, с. 756-759].

В анализе А.Ю. Урманчиевой существенны три допущения (высказанные с большей или меньшей степенью эксплицитности): 
(6) а. Альтернирующие глаголы стативны.

b. Стативность альтернирующих глаголов имеет производный характер.

с. Альтернирующие глаголы на $-\varnothing^{i}$ и $-(y) o$ не показывают систематических семантических различий.

Каждое из этих утверждений нуждается в уточнении. Начнем с (5a).

Важнейший семантический критерий стативности - свойство истинности в точке ([Taylor, 1977; Bennet, Partee, 1977; Dowty, 1977, 1979] и последующая литература, см. обсуждение в [Татевосов, 2016]). Истинность в точке, как явствует из названия, - это свойство, состоящее в том, что истинность предложения можно оценить применительно к моменту времени. Про любой временной интервал и про любой момент времени можно сказать, например, истинно ли предложение Володя живет в Цюрихе. Чтобы оценить, верно ли, что Володя гуляет в парке, необходим интервал; применительно к моментам это предложение не истинно и не ложно. Идея истинности в точке отражает динамический характер предикатов типа гулять: чтобы ответить на вопрос, удовлетворяет ли происходящее такому описанию, требуется ненулевой временной промежуток.

С этой точки зрения в списке случаев (5a-f) самый выигрышный для стативного анализа материал - это (5a) и (5b). Глаголы типа 'сидеть' и 'быть положенным' в (5a), безусловно, стативны, как и 'быть бездомным' в (5b).

Хабитуальные предикаты в (5e), будучи производными предикатами индивидного уровня ([Krifka et al., 1995] и последующая литература), также удовлетворяют свойству истинности в точке. Если верно, например, что Володя читает «Искру» по утрам, то перед нами свойство, которым индивид обладает в любой момент времени, независимо от того, занят ли он в этот момент чтением «Искры». «Одорфактивные» глаголы в (5c) также удовлетворяют этом критерию.

Остаются (5d) и (5f). Имперфективные глаголы с суффиксом мбӑ \{mpø-\} в (5d), которые мы, вслед за Т. Салминеном, называем дуративами, выражают, среди прочего, значение прогрессива. А.Ю. Урманчиева, по-видимому, рассматривает этот случай как нуждающийся в специальном объяснении. Действительно, в типологически ориентированной грамматической семантике, начиная по меньшей мере с [Comrie, 1976], преобладает убеждение, что прогрессивы, которые образуются только от динамических предикатов, и сами представляют собой динамические предикаты. Соответственно, А.Ю. Урманчиева пытается сохранить стативный анализ для этого случая, предполагая, что значение прогрессива следует рассматривать как продукт диахронического развития исходного 
стативного значения. «Следует предполагать, - пишет она, - что развитие общей инкомплетивной семантики шло путем расширения значения от результатива к имперфективу: объектный/субъектный результатив > имперфектив» [Урманчиева, 2013, с. 758-759]. Отвлекаясь от вопроса о том, насколько эмпирически реален путь диахронического развития из результатива в имперфектив, следует заметить, что для стативного анализа имперфективные глаголы с суффиксом -мбӑ \{mpø-\} могут быть менее проблематичны, чем кажется А.Ю. Урманчиевой (хотя и не по той причине, о которой она пишет). В семантических исследованиях прогрессива имеется традиция (не преобладающая, но устойчивая, см., например, [Vlach, 1993]) анализировать прогрессивы как стативы. Это позволяет, в частности, объяснить факты, где прогрессивы и стативы образуют по какому-то параметру естественный класс. Один из самых известных примеров в этом ряду - интерпретация английского перфекта. Так называемый универсальный перфект, когда описываемая ситуация имеет место в течение всего фокусного времени, допускается от стативных глаголов и от прогрессивов (ср. I have been sick since yesterday и I have been reading Das Kapital since yesterday), но исключается в прочих случаях (\# I have read Das Kapital since yesterday.) Соответственно, имперфективы на -мбӑ \{mpø-\} можно было бы рассматривать не как аргумент против анализа альтернирующих глаголов как стативов, а как аргумент в пользу стативного анализа прогрессивов.

Самый нетривиальный случай в списке в (5), на наш взгляд, представлен в (5f). С точки зрения А.Ю. Урманчиевой, у глаголов типа сэдӑко $(c b)$ ssedøko\} 'заниматься шитьем мелких предметов' «ситуация представлена не как динамически развивающаяся, когда субъект постепенно реализует определенное действие над объектом, а как стативная, когда предикат используется для характеризации субъекта» [Урманчиева, 2013, с. 758] . Возможно, это верно, однако для вынесения окончательного суждения, как нам кажется, недостает материала. Если эти глаголы имеют только хабитуальную интерпретацию (скажем, 'заниматься шитьем мелких предметов в порядке основного заработка'), описание А.Ю. Урманчиевой представляется оправданным. Однако если они допускают также и эпизодическую интерпретацию (например, 'заниматься шитьем мелких предметов в момент наблюдения'), вывод об их стативном характере начинает казаться несколько преждевременным. По всем признакам в этом случае перед нами представитель вендлеровских деятельностей, или динамический непредельный предикат.

Составить окончательное представление о характеристиках глаголов этого типа, однако, мешает то, что они отстоят от исходного глагола

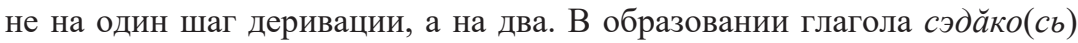
\{sedøko\} 'заниматься шитьем мелких предметов' от исходной основы 
cэдӑ $(c b)\{\mathrm{sedø \}}$ ‘сшить что-либо для кого-либо’ (см. [Терещенко, 1965, c. 581]) участвует не только элемент -(y)o, но и показатель $-(\eta) g\{(\mathrm{ng}) \mathrm{k}\}$. Пока его роль в деривационном процессе не прояснилась, делать выводы о вкладе -(y)o в интерпретацию кажется преждевременным. Этот случай в последующих рассуждениях мы оставим в стороне.

К сожалению, для стативного анализа есть данные, намного более проблематичные, чем дуративы на мбӑ \{mpø-\} или глаголы из (5f). Рассмотрим инхоативы в (7)-(8):

(7) ji? loxomb^la.

yiq loxo-m-pø-la- ${ }^{\circ}$

вода кипеть-M-DUR-INCH-GFS.3SG.S

'Вода начала кипеть.'

(8) ji? loxombali.

yiq loxo-m-pø-li

вода кипеть-M-DUR-INCH.GFS.3SG.S

'Вода кипит.'

В (7) представлен вариант с ауслаутом на - $a$, лохомбӑла(сb) \{loxompøla\}; в (8) - один из двух альтернирующих глаголов лохомбӑлӑ(сь) $\left\{\right.$ loxompølø $\left.{ }^{1}\right\}$ или лохомбӑлё (cb) \{loxompølyo $\}^{7}$. (7) описывает ситуацию 'кипеть', которую никак невозможно охарактеризовать как состояние, не придав этому понятию слишком расширительное толкование. Перед нами, несомненно, динамический непредельный процесс.

Другая пара инхоативов показана в (9)-(10), где альтернирующий вариант также описывает не состояние, а процесс ${ }^{8}$.

\begin{tabular}{|c|c|c|}
\hline $\begin{array}{l}\text { (9) } w^{j} s^{j a} \\
\text { wasya }\end{array}$ & $\begin{array}{l}j i d m \\
\text { yid }^{\circ}-\mathrm{m}\end{array}$ & $\begin{array}{l}x \wedge m d a l a . \\
\text { xømta-la- }\end{array}$ \\
\hline Вася & вода-АСС & лить-INCH-GFS.3SG.S \\
\hline \multicolumn{3}{|c|}{ 'Вася начал лить воду.' } \\
\hline 10) $j i ?$ & xımdali. & \\
\hline yiq & xømta-li & \\
\hline вода & лить-INCH. & \\
\hline
\end{tabular}

${ }^{7}$ Форма аориста 3SG.S у всех альтернирующих глаголов образуется одинаково (см. таблицу 1), поэтому только по примерам типа (8) невозможно понять, имеем ли мы дело с основой на $\varnothing^{i}$, лохомбӑлӑ(cb) \{loxompøløi\}, или с основой на $(y)$, лохомбӑлё $(c b)$ \{loxompølyo\} (см. подробнее [Татевосов, 2018]).

${ }^{8}$ В отличие от форм субъектного спряжения, формы возвратного спряжения от обоих глаголов описывают вхождение в результирующий процесс. В (i) и (iii) показано возвратное спряжение от глаголов на -a: лохомбӑла(сb) \{loxompøla\} и хӑмдала(сb) \{xømtala\}, в (ii) и (iv) - от их альтернирующих аналогов:

(i) ji? loxombalej? yiq loxo-m-pø-le-yo-q 


\section{'Вода льется.'}

Каузативные глаголы демонстрируют тот же диапазон возможностей, что и инхоативные. В (11)-(12) показан каузатив глагола мӑнза(cb) \{mønса\} 'шевелиться'.

(11) $w_{a s}^{j} a$ wasya

Вася nac ${ }^{j}$ ekim

ngacyeki-m

'Вася пошевелил ребенка.' mınza-pta.

mønca-bta- ${ }^{\circ}$

шевелиться-CAUS-GFS.3SG.S

(12)
yacieki
mınzapti.
ngacyeki
mønca-bti
ребенок
шевелиться-CAUS.GFS.3SG.S
'Ребенок шевелится.'

С морфологической точки зрения, (9)-(10) и (11)-(12) параллельны (7)-(8): основа на - $а$ в (9) и (11), альтернирующая основа в (10) и (12). Как и в (8), ситуации, описываемые в (10) и (12), не представляется возможным описывать как стативные. Стативность как общий семантический знаменатель для альтернирующих глаголов делается эмпирически неприемлемой.

\section{3. Исходное и результирующее состояния}

Опираясь наблюдения над глаголами типа (7)-(12), а также на ту часть соображений из [Урманчиева, 2013], которые не вызывают

вода кипеть-M-DUR-INCH-SFS -3SG.R

'Вода закипела.'

(ii) ji? loxombali?.

вода кипеть-M-DUR-INCH.SFS-3SG.S

'Вода закипела.'

(iii) ji? $\quad \mathrm{x} \wedge$ mdalej?.

yiq xømta-le- ${ }^{\circ}-\mathrm{q}$

вода лить-INCH-SFS-3SG.R

'Вода начала литься.'

(iv) ji? $\quad \mathrm{x}$ m mdali?.

yiq xømta-li-q

вода лить-INCH.SFS-3SG.R

'Вода начала литься.'

Это, видимо, происходит потому, что показатели возвратного спряжения не являются семантически нейтральными (в отличие от показателей субъектного) и модифицируют событийную структуру, возникающую на предшествующих этапах деривации (см. [Татевосов, 2016b], где выдвигается гипотеза, что роль возвратного спряжения состоит в создании отношения между двумя событиями). Из-за этого семантика форм в (i)-(vi) практически не различается. Поэтому, если мы хотим увидеть подлинную роль «альтернирующих ауслаутов», следует ограничиться формами субъектного спряжения.

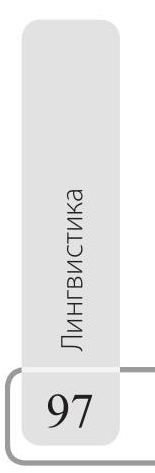


содержательных возражений, можно попытаться сформулировать новое обобщение.

Сравним глаголы в (7), (9) и (11) с их аналогами на альтернирующий гласный в (8), (10) и (12). (7) описывает событие, которое состоит в том, что описываемая ситуация достигает кульминации, после которой возникает процесс кипения. (8) вводит в рассмотрение сам этот процесс. Двухместный предикат 'начать лить' в (9) описывает неспецифицированную деятельность агенса (например, взял бочку, наклонил, открыл кран), в результате которой пациенс (вода) достигает кульминации, после чего возникает процесс 'литься'. Альтернирующий дериват в (10) вновь описывает этот последний процесс. В результирующем процессе участвует только пациенс, но не агенс (роль агенса ограничена участием в каузирующем подсобытии). Поэтому альтернирующий дериват оказывается одноместным пациентивом, как видно из неприемлемости (13), у которого сохранены оба аргумента.

$\begin{array}{lll}* \text { was }^{j a} & \text { jidm } & \text { xımdali. } \\ \text { wasya } & \text { уid }^{\circ}-\mathrm{m} & \text { хømta-li } \\ \text { Вася } & \text { вода-АCС } & \text { лить-INCH.GFS.3sG.S } \\ \text { 'Вася начал лить } \| \text { льет воду.' }\end{array}$

Сравнение форм субъектного спряжения исходного каузатива и альтернирующего деривата в (11)-(12) вновь показывает, что во втором предложении речь идет о событии, которое имеет место после кульминации события из первого предложения.

Эти примеры подводят нас к следующему семантическому обобщению по поводу альтернирующих глаголов:

(14) Альтернирующий гласный ауслаута основы представляет собой морфему, которая выделяет результирующее подсобытие (состояние или процесс) из события, описываемого исходным глаголом.

(14) отменяет (5a). Согласно (14), роль альтернирующих гласных модификация структуры события, а не просто придание глаголу стативной акциональной характеристики. (14), однако, не затрагивает (5b-c).

Гипотеза в (14) полностью совместима с фактами, которые мы видим в (7)-(12). Однако можно ли на этом основании говорить о том, что любые альтернирующие глаголы описывают результирующее подсобытие, вычленяемое из той событийной структуры, которая соотносится с неальтернирующим вариантом?

В этом вопросе требуется большая осторожность, поскольку материал, по меньшей мере, частично совместим и с другим анализом. 'Кипеть' 
в (8) и 'литься' в (10) - это не результирующие процессы, а исходные. Не 'кипеть' получается из 'закипеть' выделением результирующего подсобытия, а 'закипеть' из 'кипеть' посредством перехода от дескрипции процесса к дескрипции события, приводящего к его возникновению. Точно так же, в (9)-(10), возможно, исходен не 'начать лить', а 'литься'. Соответственно, в таком случае вместо (14) верное обобщение начинает выглядеть как (15):

(15) Альтернирующий гласный является морфологической этикеткой простой событийной структуры (состояния или процесса). Неальтернирующий гласный указывает на приращение подсобытия, ведущего к ее возникновению.

(15) отменяет не только (5a), но и (5b). Согласно (15), альтернирующие гласные указывают на событийно-структурную элементарность предиката. Состояния и процессы вводятся в рассмотрение не как результирующие, а как непроизводные.

Провести (15) в жизнь для всех альтернирующих глаголов, однако, невозможно. Это становится очевидно, как только мы вспоминаем, что bta $\{\mathrm{bta}\}$ в (11)-(12) - это каузативный показатель. Событийная структура каузатива не может быть элементарной: она по необходимости содержит минимум два подсобытия (см., например, [Lyutikova, Tatevosov, 2014] и цитируемую там литературу). Соответственно, альтернирующий гласный в (12) не может находиться в составе этого глагола по причинам, описанным в (15).

В этом месте мы готовы предложить основную гипотезу этого исследования, для которой ключевым допущением выступает отказ от (5c). Альтернирующие элементы $\varnothing^{i}$ и $(y) o$ играют разную роль в простроении событийной структуры:

(16) Альтернирующий $\varnothing^{i}$ вводит простую событийную структуру (состояние или процесс) в рассмотрение как исходную, в соответствии с (15), а (y)o - как результирующую, сообразно (14).

В следующем разделе мы представим несколько наблюдений, подкрепляющих эту гипотезу.

\section{4. Событийные структуры}

Первый аргумент в пользу (16) опирается на следующее соображение. Если некоторая дескрипция возникает путем извлечения ее из более сложной дескрипции, последняя должна быть представлена отдельной 
лексической единицей. Например, результатив ([Недялков, Яхонтов, 1988] и последующая литература) со значением 'сидеть' - только тогда результатив, когда есть глагол со значением 'сесть', от которого он образуется. Если такого нет, то 'сидеть' - не результатив, а непроизводный глагол состояния.

В более общем случае семантическое отношение вида «вхождение в результирующее подсобытие vs само результирующее подсобытие» возможно, только если в языке есть оба элемента. Если (16) верно, глаголы на $y(o)$ должны находиться в регулярных морфологических отношениях с глаголами, описывающими соответствующие изменения состояния. Для любого (y)o-глагола должен найтись производящий глагол, обозначающий переход в новое состояние или возникновение нового процесса.

Насколько мы можем судить по нашему материалу и по материалу словарей Н.М. Терещенко и Т. Салминена, предсказание выполняется. В этом убеждает наличие пар непроизводных глаголов вида хона(сb) \{xona\} 'идти спать, ложиться спать' и хонё(сь) \{xonyo\} 'спать' в (3a), ңзамдӑ(сь) \{ngamtø\} 'садиться' и нцамдё(сь) \{ngamtyo\} 'сидеть' и т.д., а также отсутствие непарных $y(o)$-глаголов. Мы заключаем, что альтернирующий (y)o действительно выделяет из сложной событийной структуры элементарное результирующее подсобытие.

Этот показатель имеет семантику, сходную описанной для результатива в [Недялков, Яхонтов, 1983], но не идентичную последней. Результативы вводят в рассмотрение только результирующее состояние и не у всех глаголов, а у только у предельных, описывающих вхождение в состояние, таких как 'открывать', 'ломаться', 'засыпать' или 'садиться'. Результативы от них означают соответственно 'быть открытым', ‘быть сломанным', 'спать' и 'сидеть'. В случае с (y)o мы получаем возможность выделить не только результирующие состояния, но и результирующие процессы.

Глаголы с альтернирующим $\varnothing^{i}$ устроены, как кажется, иначе. Выше уже упоминались дуратив и хабитуалис из (4d-e). Соответствующие примеры представлены в (17) и (18).
(17) was $^{\mathrm{j} a}$ xid $^{\mathrm{j} a m}$ wasya xidya-m $\mathrm{x} \wedge l$ lamb ${ }^{\mathrm{j}} \mathrm{i}$ Вася тарелка-АсС xøl' ${ }^{\circ}$ ta-mpyi *xıltamb $\Lambda$ $\mathrm{x} ø \mathrm{l}^{\circ}$ ta-mpø- ${ }^{\circ}$ *xultamba. xøl ${ }^{\circ}$ ta-mpa- ${ }^{\circ}$ мыть-DUR-GFS.3SG.S 'Вася моет тарелку.' 


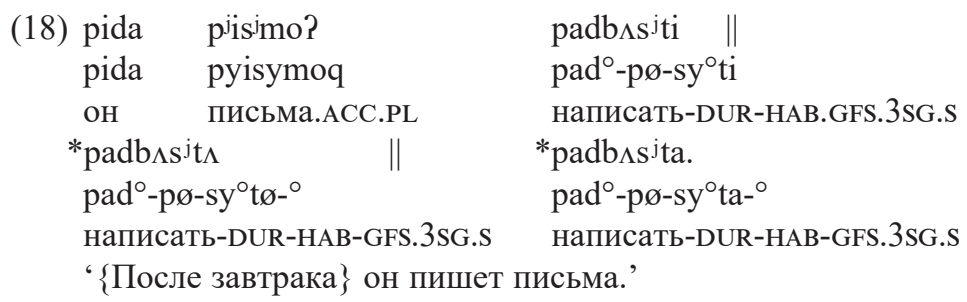

Можно ли содержание этих предложений понимать как результирующее подсобытие какого-то события? Полностью исключить такую возможность нельзя. Соответствующие дескрипции имели бы значение 'войти в процесс мытья тарелки' и 'войти в состояние постоянного писания...'. Однако здесь выясняется примечательный факт: мы никогда не находим предикатов с таким значением. Его могли бы иметь варианты с $a$ или неальтернирующим $\varnothing^{\wedge}$, но дуратив и хабитуалис - это ровно те деривации, которые не образуют таких вариантов. В (16)-(17) [xлltambs] и $\left[\mathrm{padb} \Lambda \mathrm{s}^{\mathrm{j} t \Lambda}\right.$ - это формы субъектного спряжения гипотетических глаго-

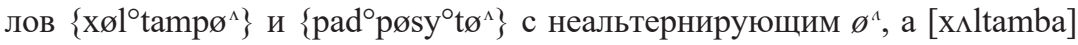

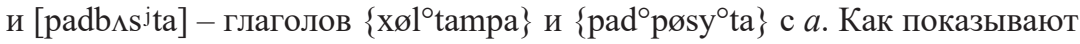
(16)-(17), такие формы неграмматичны. Дуративы на $\left\{m p \varnothing^{\wedge}\right\}$ и $\{\mathrm{mpa}\}$, а также хабитуалисы на $\left\{\right.$ sy $\left.^{\circ} \boldsymbol{t}^{\wedge}\right\}$ и $\left\{\mathrm{sy}^{\circ} \mathrm{ta}\right\}$ не зафиксированы ни в словарях, ни в нашей базе данных. Это отсутствие выглядит слишком систематическим, чтобы объяснять его случайным совпадением.

Самое естественное предположение состоит в том, что значение типа 'вхождение в результирующее подсобытие' для хабитуалиса и дуратива вовсе недоступно. Следовательно, состояние или процесс, который обозначают эти дериваты, не описывается как результирующее.

Именно так, по-видимому, устроены и пары типа (2), повторяемые в (19). 'Быть заснеженным' - это не результирующее подсобытие для 'наполнить, набить что-либо снегом, букв. заснежить', а 'быть прикушенным, зажатым, прищемленным' - для 'впиться чем-либо во что-

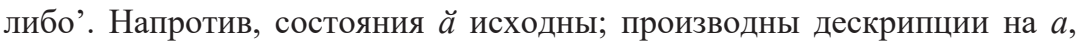
описывающие их возникновение.

(19) a. cырumă(cb) \{siryitø\}

'быть заснеженным, быть покрытым снегом'

сырита (cb) \{siryita\}

'наполнить, набить что-либо снегом'

b. сяклӑ(сь) $\left\{\operatorname{syak}^{\circ} \mathrm{l} \varnothing\right\}$

'быть прикушенным, зажатым, прищемленным'

сякла(сь) $\quad$ syak $\left.^{\circ} \mathrm{la}\right\}$

'впиться чем-либо во что-либо.' 
Если эта линия рассуждения верна, начинают выстраиваться определенные ожидания по поводу дистрибуции $\varnothing^{i}$ и $(y) o$ у глаголов с показателем каузатива. Выше мы видели каузатив мӑнзабта(сb) \{møncabta\} 'шевелить' с показателем бта \{bta\}. Этот каузатив имеет в ауслауте неальтернирующий - $a$. Каузативы по необходимости имеют сложную событийную структуру, как минимум содержащую каузирующее и каузируемое подсобытия. Из этой структуры можно выделить элементарное процессное или стативное подсобытие, однако оно с неизбежностью будет производным: соответствующая дескрипция будет результатом преобразования исходной каузативной структуры. Если же верно, что $\varnothing^{i}$ маркирует процессы и состояния как непроизводные, мы предсказываем, что каузатив с таким ауслаутом невозможен. Насколько можно судить по имеющемуся материалу, это действительно так: ни в наших данных, ни в словарях не зафиксировано ни одного каузатива с показателем бтӑ $\{\mathrm{btø}\}$.

Вторая часть предсказания также очевидна: поскольку процессное или стативное подсобытие, вычленяемое из каузативной структуры, это результирующее подсобытие, а не исходное, для построения соответствующей дескрипции используется элемент (y)o. Эта часть также выполняется: в словаре представлено достаточное количество глаголов с показателем каузатива, различающихся именно на $a$ и $(y) o$, причем различающихся ожидаемым образом. Некоторая их часть иллюстрируется в (20):

(20) а. нцадабта (сь) \{ngadabta\}

'приподнять (один конец чего-либо)'

нзадабтё $($ сь $) \quad$ ngadabtyo\}

'быть припо́днятым (об одном конце чего-либо)'

b. нуодабта (сь) \{ngodabta\}

'запрокинуть назад голову, задрав кверху нос.'

нзодабтё (cb) \{ngodabtyo\}

'быть с запрокинутой головой, с задранным кверху носом'

c. пӑщ̧гӑбта (сь) \{pøngøbta\}

'скрутить (например нитки, жилы для шитья)'

пӑңгӑбтё $(c b) \quad$ \{pøngøbtyo\}

'быть кривым, искривленным (например о дереве, туловище человека)'

d. поркабта (сь) \{porkabta\}

'поднять, поставить что-либо вертикально'

поркабтё $(\mathrm{cb}) \quad$ \{porkabtyo

'быть выставленным, высунутым; быть поднятым торчком.' 
В каждой из этих пар второй компонент описывает результирующее состояние, возникающее при осуществлении события, обозначаемого первым компонентом, как и ожидается.

Точно так же соотносятся и глаголы в (11)-(12) выше. В (11) представлена форма субъектного спряжения каузативного глагола мӑнзабта (cb) \{møncabta\} 'шевелить', а в (12) - глагола мӑнзабтё( $(c b)$ $\{$ møncabtyo\} 'шевелиться'.

\section{5. Альтернирующие глаголы с $\varnothing^{i}$}

Если (16) верно, то неальтернирующие глаголы с $a$ или $e$ противопоставлены альтернирующим глаголам с $\varnothing^{i}$ не как вхождение в результирующую ситуацию и результирующая ситуация, а как исходная ситуация и вхождение в эту ситуацию.

В этом разделе мы рассмотрим дополнительные факты, с одной стороны, подкрепляющие этот вывод, в с другой - вносящие в него некоторое уточнение.

Среди пар глаголов, различающихся на неальтернирующий $a$ (или $e$ ) и альтернирующий $\varnothing^{i}$, обнаруживаются такие, где элемент с $\varnothing^{i}$ вовсе невозможно анализировать как описание результирующого состояния, обозначаемого элементом с $a$ или $e$. Вот несколько примеров:

(21) а. хавопятӑ $($ сь $) \quad\{$ xawopyatø\}

'носить металлические подвески в ушах (о женщине)'. хавопята $($ сь $) \quad\{$ xawopyata\} 'надеть кому-либо металлические подвески в уши'.

${ }^{9}$ По форме аориста 3SG.S mınza-pti \{mønca-bti\} невозможно определить, имеем ли мы дело с глаголом мӑнзабтё (cb) \{møncabtyo\} с (y)о или мӑнзабтӑ(cb) \{møncabtøi\} с $\emptyset^{i}$. Аористы 3SG.S этих двух глаголов омонимичны. На помощь приходит отрицательный аорист, который образуется с использованием вспомогательного глагола в комбинации с коннегативом. В коннегативе глаголов $\emptyset^{i}$ ауслаутный сегмент преобразуется в $u$, а у глаголов на $(y) o-$ в $y u$ :

(i) $*^{*} \mathrm{n}_{\mathrm{i}} \quad$ mınzabtu? nyi mønca-btu-q

NEG.3SG.S шевелиться-CAUS-CNG

(ii) $\mathrm{n}^{\mathrm{ji}} \quad \mathrm{m} \wedge$ nzabtiu? nyi mønca-btyu-q

NEG.3SG.S шевелиться-CAUS-CNG

(i) и (ii) показывают, что отрицательный аорист 3SG.S имеется у мӑнзабтё(сb) $\left\{\right.$ møncabtyo\} в (ii), но не у мӑнзабтӑ(cb) \{møncabtøi ${ }^{\text {\} }}$. Экстраполируя это обобщение на утвердительные формы, мы приходим к выводу, что (12) - также форма мӑнзабтё(сь) $\{$ møncabtyo $\}$. 
(21) b. хӑлакӑтӑ(cb) $\quad$ xølakøtø\}

'быть одетым в верхнюю одежду с закрытыми рукавичками (о ребенке)'.

хӑлакӑта $(\mathrm{cb}) \quad\{$ xølakøta $\}$

'пришить закрытую рукавичку к детской одежде'.

с. сындӑ(сb) \{sintø\}

'заниматься тем, что доставать продукты из продуктовой

нарты' = 'использовать запас'

сында

'отложить про запас'

d. вӑдетӑ $(c b) \quad\{$ wødyetø\}

'удить, заниматься ужением' (неперех.)

вӑдета $(c b) \quad\{$ wødyeta\}

'поддеть, зацепить крючком'

(21a) очень похож на соотношение 'вхождение в состояние' - 'результирующее состояние'. Однако если присмотреться внимательнее, становится ясно, что 'носить серьги' - это не результат 'надеть кому-либо серьги'. Результирующее состояние - это ‘быть в серьгах”. Между “быть в серьгах’ и 'носить серьги' есть небольшая, но ненулевая семантическая дистанция. Первое - это состояние, а второе - деятельность, участник которой имеет агентивные свойства. 'Носить серьги' - это 'делать так, чтобы в релевантных ситуациях имело место состояние 'быть в серьгах'.

В (21b) глагол на $\varnothing^{i}$ отстоит еще на один шаг дальше от результирующего состояния той ситуации, которую описывает глагол на $a$. Состояние, соотносящееся с 'пришить закрытую рукавичку к детской одежде' (глагол хӑлакта $(c b)\{$ xølakøta\}), - это 'иметь в качестве составной части пришитую рукавичку’. В значении хӑлактӑ(cb) \{xølakøtøi\} этот компонент есть, но есть и некоторое приращение: 'быть одетым в верхнюю одежду с закрытыми рукавичками' - это 'использовать по назначению предмет, находящийся в состоянии 'иметь в качестве составной части пришитую рукавичку".

В (21c) соотносимое состояние для 'отложить про запас' - это 'быть в запасе' ( $\approx$ ‘находиться в продуктовой нарте'). 'Заниматься тем, что доставать продукты из продуктовой нарты’ - это другая ситуация, которая, однако же, тоже имеет непосредственное отношение к этому состоянию. Ее можно описать как 'использовать по назначению объект, находящийся в состоянии 'быть в запасе'.

В (21d) семантика глагола на $\varnothing^{i}$ уходит еще дальше от глагола на $a$. Ситуации 'подцепить на крючок' соответствует состояние 'быть на крючке'. Глагол на $\varnothing^{i}$ вновь включает это состояние в свое толкование, 
однако иначе, чем в предыдущих случаях. На этот раз он описывает ситуацию 'делать так, чтобы некоторые объекты входили в состоянии ‘быть на крючке'.

Семантика глаголов на $\varnothing^{i}$ из (21) постепенно проясняется. Все они представляют собой вендлеровские деятельности, которые некоторым образом опираются на заданное состояние. В (22a) общий знаменатель дан в неформальной формулировке; в (22b) - на несколько более эксплицитном теоретико-модельном языке.

(22) Семантический шаблон для глаголов из (21):

а. X делает так, чтобы между ним и состоянием $\mathrm{s}$ с дескриптивными свойствами $\mathbf{S}$ имело место отношение $\mathbf{R}$.

b. $\left\|\mathrm{V}^{ø}\right\|=\lambda \mathrm{x} . \lambda \mathrm{e}$. activity $(\mathrm{e}) \wedge \operatorname{agent}(\mathrm{x})(\mathrm{e}) \wedge \exists \mathrm{s} . \mathrm{R}(\mathrm{x})(\mathbf{S})(\mathrm{s})(\mathrm{e})$

Схема в (22) представляет собой шаблон одноместного агентивного глагола, семантика которого строится вокруг состояния с заданными дескриптивными свойствами. Положительный компонент значения каждого такого глагола - это информация о характеристиках состояния, заключенная в дескрипции S («лексическая константа» в терминах [Rappaport Hovav, Levin, 1998]; в (22b) выделена полужирным). Она отвечает за семантическое своеобразие каждого глагола. Остальные компоненты у всех единиц этого класса одинаковы. Отношение R, однако, допускает некоторую подвижность в интерпретации, определяемую контекстными и энциклопедическими знаниями.

Подставляя в качестве $\mathrm{S}$ конкретную дескрипцию состояний и фиксируя значение R, мы получаем лексические значения для (21a-d). Bозможные варианты реализации $\mathrm{R}$ для этих случаев показаны в (23a-c).

Для 'носить серьги' в (21a) задействуется отношение REPRESENT из (23a), а состояние S фиксируется как 'быть в серьгах’. Глагол хаво$n я m a ̆(c b)\{$ xawopyatø\} получает толкование ' $x$ делает так, чтобы в любой контекстно-релевантной ситуации $v$ он находился в состоянии $s$, удовлетворяющем дескрипции 'быть в серьгах'. Как представляется, именно в этом и состоит представленное в словаре значение 'носить серьги'.

Для (21b-c) с помощью отношения MAKE.USE из (23b) возникает толкование ' $x$ делает так, чтобы в любой контекстно релевантной ситуации $v$ он использовал по назначению сущности, находящиеся соответственно в состоянии 'иметь в качестве составной части пришитую рукавичку' и 'быть отложенным про запас в продуктовую нарту', Эти сущности не являются актантами результирующего глагола: они подвергаются семантической инкорпорации через связывание квантором существования, как в (23b). 
(23) Доступные значения для отношения R

a. $\operatorname{REPRESENT}(\mathrm{x})(\mathrm{S})(\mathrm{s})(\mathrm{e})=1 \equiv$ в любой контекстно-релевантной подситуации $v$ ситуации $e, v \subseteq e, x$ находится в состоянии $s$, удовлетворяющем дескрипции $\mathrm{S}$

b. MAKE.USE(x)(S)(s)(e) = 1 в любой контекстно-релевантной подситуации $v$ ситуации $e, v \subseteq e, x$ использует по назначению некоторый $y$, находящийся в состоянии $s$, удовлетворяющем дескрипции $\mathrm{S}$;

c. $\operatorname{ACQUIRE}(\mathrm{x})(\mathrm{S})(\mathrm{s})(\mathrm{e})=1 \equiv$ в любой контекстно-релевантной ситуации $v$ ситуации $e, v \subseteq e, x$ приобретает некоторый $y$, находящийся в состоянии $s$, удовлетворяющем дескрипции $\mathrm{S}^{10}$.

В (21d), наконец, толкование ' $x$ делает так, чтобы в любой контекстно-релевантной ситуации $v$ он приобретает некоторый $y$, находящийся в состоянии $s$, удовлетворяющем дескрипции 'быть на крючке' получается при помощи отношения в (23c), в котором участвует состояние 'быть на крючке'.

Важное отличие (23a) от (23b-c) состоит в том, что только в первом случае внешний аргумент, агенс, выступает также носителем состояния. В прочих случаях это другой индивид, соответствующий связанной квантором существования переменной. Такая семантическая структура представляется типологически достаточно необычной для глаголов класса деятельностей. Классические деятельности в более описанных языках не никогда не содержат семантически инкорпорированного актанта (см., среди многих других [Clark, Clark, 1979; Rappaport Hovav, Levin, 1998; Hale, Kayser, 2002; McIntyre, 2014]). В этом отношении ненецкий материал представляет особый интерес для теории аргументной структуры, однако у нас нет возможности обсуждать этот сюжет подробнее в пределах этой статьи.

Основное обобщение, которое позволяют сделать эти наблюдения, состоит в том, что пары в (21a-d) не связаны друг с другом отношением непосредственной семантической деривации. Напротив, они оба представляют собой семантические дериваты, независимо возникающие из одного источника, дескрипции состояний, как показано на схеме в (24) для пары в (21d).

\footnotetext{
${ }^{10}$ Для вӑдетӑ(cb) \{wødyetø\} 'удить, заниматься ужением’ значение, близкое к наблюдаемому, можно было бы получить и иным путем - антипассивной деривацией от вӑде$m a(c b)$ \{wødyeta\} 'поддеть, зацепить крючком'. При такой деривации позиция внутреннего аргумента с ролью пациенса связывается квантором, в результате чего образуется непереходный глагол, описывающий деятельность агенса. Такой сценарий, однако, неприменим для других ø-глаголов в (20), и с этой точки зрения предложенный нами вариант выглядит предпочтительнее.
} 
СОсТОЯнИЕ

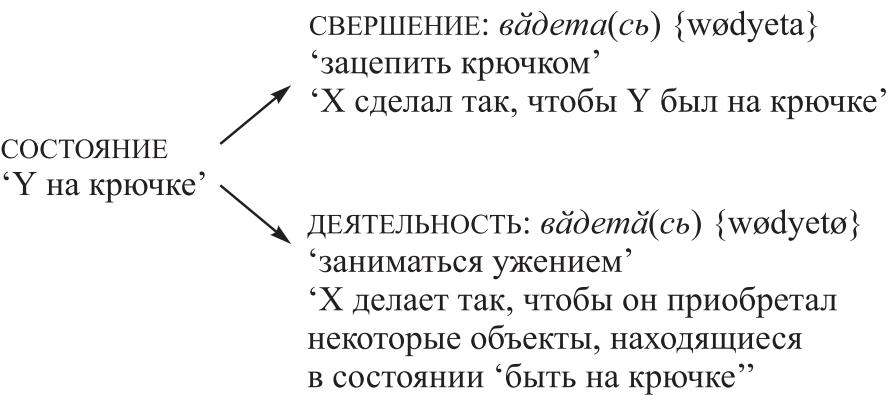

В теоретико-модельных терминах каждой их этих возможностей можно сопоставить анализ в (25):

(25) а. Состояние: $\lambda$ x. $\lambda$ s.на.крючке(x)(s)

b. Свершение: $\lambda y . \lambda x . \lambda e$. activity $(\mathrm{e}) \wedge \operatorname{agent}(\mathrm{x})(\mathrm{e}) \wedge$ $\exists$ s: cause(s)(e) $\wedge$ на.крючке(y)(s)

с. Деятельность: $\lambda$ x. $\lambda$ e. activity $(\mathrm{e}) \wedge \operatorname{agent}(\mathrm{x})(\mathrm{e}) \wedge$ $\exists \mathrm{y} \exists \mathrm{s}$ : acquire(x)((на.крючке)(y))(s)(e).

Семантическое представление деятельностей в (25c), где в него встраивается дескрипция состояния, непосредственно соотносится с идеей, содержащейся в первом декомпозициональном анализе глаголов этого класса, предложенном Д. Даути [Dowty, 1979]. Анализ показан в (26):

(26) Шаблон деятельностей Д. Даути

DO $\left(\mathrm{x}, \pi\left(\mathrm{x}, \mathrm{y}, \mathrm{y}^{\prime}, \ldots\right)\right)$

В этом шаблоне предикат $\pi$ - это предикат над состояниями, выступающий аргументом оператора DO. Второй аргумент DO - индивид, представленный переменной $x$, а все вместе это значит ' $x$ делает так, чтобы имело место состояние $\pi$ '. Сам $x$ - обязательный участник $\pi$, но кроме него, допускаются и любые другие участники $y, y^{\prime}$ и т.д. Последующие теории предикатной декомпозиции отказались от этой идеи Д. Даути: деятельность представляет собой усилия агенса по созданию и поддержанию состояния. В большой степени это, по-видимому, произошло из-за отсутствия на тот момент убедительных эмпирических аргументов в пользу такой декомпозиции. Ненецкие данные можно рассматривать именно как аргумент такого рода. В (25c) аналогом Dо выступает компонент activity, а состояние вступает в более сложные отношения с агенсом, которые заданы в (23). В прочих аспектах (25c) можно рассматривать как близкий семантико-событийный аналог шаблона деятельностей из (26). 


\section{6. Общая картина}

Соединяя наблюдения из (19a-b) с анализом глаголов типа вӑдетӑ(cb) \{wødyetø\} 'удить, заниматься ужением’ из (21d), мы подходим к завершающему обобщению об альтернирующих $\emptyset^{i}$-глаголах в (27), которое графически представлено в (28):

(27) Альтернирующие $\emptyset^{i}$-глаголы могут описывать любой член тройки (НЕПРОИЗВОДНОЕ) СОСТОЯНИЕ - ДЕЯТЕЛЬНОСТЬ - СВЕРШЕНИЕ, имеющий простую событийную структуру.

(28) Непроизводные состояния, деятельности и свершения

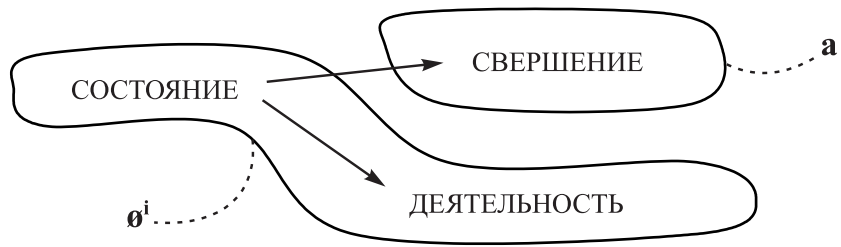

Согласно (27) и (28), $\varnothing^{i}$-глаголы могут обозначать как элементарные состояния, так и производные от них деятельности.

Важный дополнительный аргумент в пользу анализа, где $\varnothing^{i}$ привязан и к состояниям и к деятельностям, дают некоторые глагольные основы с множественными вариантами ауслаута, где $\varnothing^{i}$-вариант неоднозначен. Насколько можно судить по нашей базе данных и словарному материалу из [Терещенко, 1965], такая неоднозначность всегда одинакова: одно значение представляет собой состояние, а второе - производную от него деятельность. Это иллюстрируется примерами типа (29):

(29) а. ватӑ(cb) \{watø\} 'быть загороженным'

b. ватӑ $(c b)\{$ watø\} 'загораживать, заниматься загораживанием'.

c. вата $($ cb) \{wata\} 'загородить, обнести забором, изгородью; отгородить'

Глагол ватӑ (cb) \{watø\} описывает и непроизводное состояние в (29a), аналогичную (19a-b), и производную деятельность в (29b), которая похожа на (21a-d). Глагол вата(cb) \{wata\} в (29c) представляет собой переходное свершение. Ровно такую дистрибуцию и следует ожидать, исходя из (27)-(28).

В систему в (27)-(28) легко интегрируются глаголы на (y)o. Они, согласно (16), описывают результирующее состояние. Добавляя их к схеме (28), мы получаем (30): 
(30) Состояния, деятельности и свершения

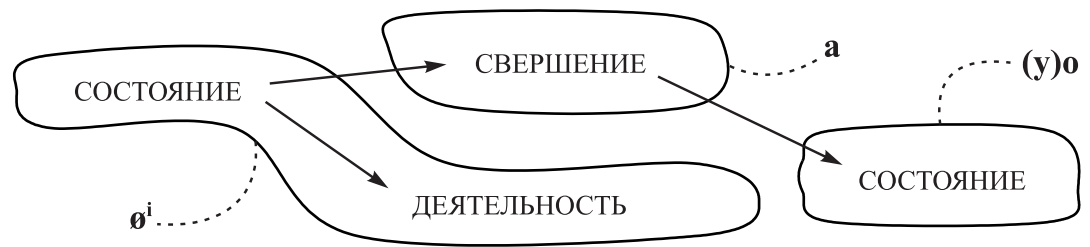

Схема в (30) придает общей картине относительную законченность. Она складывается из двух важнейших элементов. Первый - гипотеза о том, что глаголы с ауслаутом на $a$ и $e$ систематически образуют предикаты, имеющие сложную событийную структуру - два подсобытия, разделенные точкой кульминации. Такова, в частности, структура свершений. Это же, вероятно, верно (возможно, с оговорками и уточнениями) для глаголов с ауслаутом на другие неальтернирующие гласные, например, $е$ или $\varnothing^{\wedge}$.

Второй элемент - идея, что $\varnothing^{i}$-глаголы и $y(o)$-глаголы соотносятся с разными состояниями и процессами. Первые - с «исходными», вторые - с результирующими. Как кажется, для такого хода есть достаточно эмпирических оснований, которые не были в должной мере оценены в предшествующих исследованиях.

Такая недооценка неудивительна: различие между двумя типами состояний и процессов трудно увидеть, поскольку оно заключается не в их дескриптивных свойствах, а в указании на предшествующее событие. Характерный пример такого же рода - английское прилагательное open, описывающее непроизводное состояние, и причастие opened с семантикой результирующего состояния. И open, и opened обозначают состояния 'быть открытым', а в русском языке обоим соответствует отглагольный адъектив открыт(ый). Различие связано с тем, что для opened, предиката над результирующими состояниями, имплицируется предшествующая кульминация, приводящая к его возникновению, тогда как open, предикат над непроизводными состояниями, не несет никакой информации на этот счет. Дверь, удовлетворяющая описанию opened door, находится в состоянии 'открыта' постольку, поскольку имело место событие открывания. Open door ничего не сообщает о том, откуда возникло состояние. Всякая дверь из экстенсионала opened door входит в экстенсионал open door, и предикаты тем самым связаны отношением подмножества: opened $\subseteq$ open, а соответствующие предложения - отношением асимметричного следования. Тем не менее, их дескриптивные свойства не различаются вовсе, и именно из-за этого, по-видимому, 
суждения носителей об условиях истинности не отличаются достаточной отчетливостью ${ }^{11}$.

Хорошая иллюстрация к сказанному - тройка глаголов в (4), повторяемая как (31), где представлены все морфологические элементы из (30):

(31) а. ваңзлӑ (сь) $\left\{\right.$ wangk $\left.^{\circ} \varnothing \varnothing\right\}$

1) быть в берлоге (о медведе);

2) быть в снежной ямке (о куропатке);

b. вандла (сь) $\left\{\right.$ wangk $^{\circ}$ la\}

1) залечь в берлогу (о медведе);

2) зарыться в снежную ямку (о куропатке).

с. ванцлё $(c b)\left\{\right.$ wangk $^{\circ}$ lyo $\}$

1) лежать в берлоге (о медведе);

2) находиться в снежной ямке (о куропатке)

[Терещенко, 1965, с. 43].

Чем отличаются ‘быть в берлоге' в (30a) от 'лежать в берлоге’ в (30c)? Если наше предположение верно, то мы имеем дело с состоянием с одинаковыми дескриптивными свойствами. Семантическое различие, котоpoe H.M. Терещенко отразила как 'быть' vs 'лежать', сводится к тому, что к ваңзлё̈ $(c b)\left\{w^{\circ}{ }^{\circ} k^{\circ} l y o\right\}$ прилагается следующий элемент смысла: на некотором интервале, предшествующем фокусному времени, осуществилась ситуация 'залечь в берлогу', описываемая как ваңзла(сь) $\left\{\right.$ wangk $\left.^{\circ} \mathrm{la}\right\}$ из (30b).

Можно думать и о других аргументах в пользу того, что $\varnothing^{i}$-глаголы описывают непроизводные, а $y(o)$-глаголы - результирующие состояния. Например, есть один класс предикатов, где отношение подмножества между непроизводными и результирующими состояниями не возникает, и это можно пытаться использовать для того, чтобы подтвердить гипотезу в (30).

По крайней мере, в языках типа русского существуют непроизводные состояния, которые обозначаются параметрическими прилагательными, привязанными к открытой шкале, такие как длинный или холодный. Соответствующие предложения утверждают истинность положительной степени этих прилагательных: Cуn холодный описывает такое положение вещей, в котором температура супа оказывается ниже контекстно заданного стандарта. От этого прилагательного образуется

\footnotetext{
11 Заметим, что этому способствует и синкретизм в парадигме: $\varnothing^{i}$-глаголы и $y(o)$ глаголы, как мы видели, имеют идентичные формы аориста как в субъектном, так и в возвратном спряжении.
} 
глагол-свершение охлаждать, а затем с помощью пассивного причастия - дескрипция соответствующего результирующего состояния охлажден. Известная особенность этого деривационного процесса состоит в том, что истинность положительной степени при деривации не сохраняется: из охлажденный не следует холодный. Если предположить, что ненецкий язык в этом отношении устроен так же, мы можем пытаться найти такие глагольные основы, которые создают тройку типа (31), где есть и $\varnothing^{i}$-глагол, обозначающий параметрическое свойство, и (y)o-глагол. Если окажется, что отношения подмножества между экстенсионалами этих единицами нет, это будет весомый аргумент в пользу исходности состояний на ø и производности состояний на $(y) o$. Эмпирическую проверку этой возможности, однако, еще предстоит осуществить.

В завершающем разделе мы сформулируем самые общие соображения о месте ненецких «ауслаутов» на более широком типологическом и теоретическом фоне.

\section{7. Морфология событийной структуры}

Явления, о которых шла речь в предыдущих разделах, имеют в основном семантическую природу: они связаны с вариативностью в структуре глагольного значения, в составе и свойствах его компонентов и т.д. Сегмент в ауслауте основы, отражает, согласно нашей гипотезе, эту событийно-структурную вариантивность. Какой механизм обеспечивает взаимодействие событийной структуры и морфологии?

Свойства ненецких ауслаутных элементов, как кажется, неожиданным образом перекликаются с тем, как в последние годы стало возможно понимать роль так называемых «тематических элементов» в славянских языках. Русские тематические элементы показаны в (32):

(32) Тематические элементы в русском языке
а. -a(j)- дел-а-ть
ср. дел-о
b. -e(j)- бел-е-ть
ср. бел-ый
c. -ova- голос-ова-ть
ср. голос
d. $-\mathbf{i}-$
голос-И-Ть
ср. голос
e. -nu-
cox-Hy-ть
ср. сух-ой
$e^{\prime}$. -nu-
свист-ну-ть
ср. свист
f. $-\mathbf{a}-$
пис-а-ть
ср. пись-м-о
g. $-\mathbf{e}-$
обид-е-ть
ср. обид-а
h. -o-
кол-о-ть
ср. кол 
Благодаря статье А. Маранца [Marantz, 1997] и ряду последующих работ, возникла традиция анализа элементов такого рода как грамматических показателей глагольности - таких единиц, которые, соединяясь с составляющей никакой части речи, превращают ее в глагол. В (33a) показан анализ в этом духе глагола делать; роль вершины $v$, выражаемой тематическом элементом - $a(j)$-, состоит в том, чтобы превратить акатегориальный корень $(\sqrt{ })$ дел- в глагольную группу и обеспечить синтаксическую реализацию его актантной структуры (т.е. «лицензировать» ее). Существительное дело в (33b) образуется от того же корня с помощью другого грамматического элемента $n$, который, в отличие от $v$, не допускает, чтобы его комплемент имел внутренний аргумент.

(33) Делать и дело в русском языке

a.

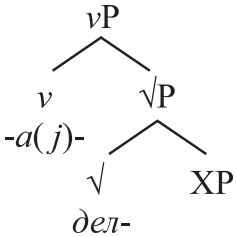

b.

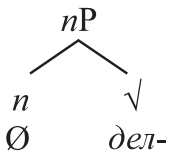

Таким образом, «тематические гласные/элементы» у глаголов - это показатели синтаксического класса, морфемы, которые представляют собой фонологические реализации вершины $v$.

В контексте нашего исследования существенно то, что благодаря такому подходу открывается возможность существенно изменить представления о морфосинтаксической функции тематических элементов. Поскольку они выступают фонологической реализацией вершины $v$, можно ожидать, что выбор элемента зависит от характеристик $v$. Характеристики $v$ могут варьировать по меньшей мере в двух измерениях: какой структурный вклад $v$ в вносит в деривацию и насколько она чувствительна к свойствам комплемента.

Это дает возможность объяснить, например, корреляцию между событийной структурой глаголов типа (по)белить и (по)белеть и выбором тематического элемента. Элемент -u- может выступать реализацией такой вершины $v$, которая способна создавать переходную глагольную группу с внутренним и внешним аргументами. Элемент -e-, с другой стороны, встречается только в непереходных структурах, в большинстве из которых описывается изменение состояния единственного актанта. В этом смысле каждый тематический элемент становится фонологической этикеткой определенного класса событийно-структурных конфигураций (хотя, конечно, не для всех единиц в (32) такие корреляции устанавливаются так же легко, как для -u- и -e-). 
Между русскими тематическими элементами и ненецкими «гласными ауслаута» начинает прорисовываться отчетливое сходство. Различия в асулауте, как выясняется, имеют в ненецком языке четкие событийно-структурные корреляты, которые описываются, например, в терминах вендлеровских классов в варианте Д. Даути [Dowty, 1979]. Конечно, они функционируют немного по-другому: дистрибуция «тематических элементов» в русском языке не чувствительна к предельности, а дескрипции результирующих состояний деривируются принципиально иначе, чем в ненецком, - при помощи причастий. Тем не менее, общие контуры системы в том и другом языке оказываются похожи.

Вот простейший набросок ненецкой системы на примере тройки в (31), где реализованы все элементы:

(34) a.

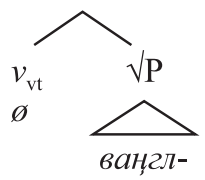

b.

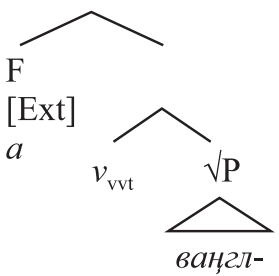

c.

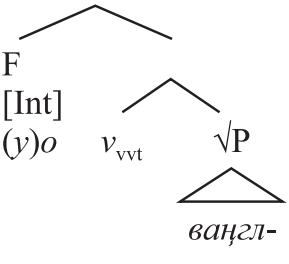

В (34a-c) мы опираемся на предположение, что в ненецком языке максимальные проекции корней, которые приобретают глагольные свойства в процесс деривации, интерпретируются как предикаты состояния или процесса. (В (34a-c) мы следуем за А. Маранцем в том, что корень лишен категориальной спецификации, но от этого допущения в последующих рассуждениях ничего не зависит.) Проекция корня соединяется с глагольной вершиной $v$, для которой мы предполагаем две разновидности с разным логическим типом. Первая, которая представлена в (34a) и обозначена как $v_{\mathrm{vt}}$, создает простую событийную структуру, денотат которой представляет собой событийный предикат логического типа $<\mathrm{v}, \mathrm{t}>$. Она допускает две семантические реализации, которые показаны в (35):

$$
\left\|v_{v t}\right\|=\left\{\begin{array}{l}
\lambda S . S \\
\lambda S . \lambda x . \lambda \text { e. activity }(e) \wedge \operatorname{agent}(x)(e) \wedge \exists s . R(x)(S)(s)(e)
\end{array}\right.
$$

Благодаря (35), выстраиваются структуры состояний и деятельностей в духе Д. Даути. Вариант (1), функция эквивалентности, соединяясь с денотатом $\sqrt{\mathrm{P}}$, дает предикат над состояниями или (неагентивным) процессами. Вариант (2) добавляет к $\sqrt{\mathrm{P}}$ агентивный компонент и дает, 
в частности, событийную структуру деятельностей. У тройки в (31) корень обозначает состояние, а при интерпретации $v_{\mathrm{vt}}$ задействуется, по-видимому, вариант (1). В (21) выше мы видели примеры глаголов на $\varnothing^{i}$ с вариантом (2).

Другая разновидность $v$, обозначенная как $v_{\text {vvt }}$, производит глагольную группу, которая имеет логический тип отношений между двумя событиями $<\mathrm{v},<\mathrm{v}, \mathrm{t}>>$. Она отвечает за сложные событийные структуры - свершения и достижения, как показано в (36):

$$
\left\|\mathrm{v}_{\mathrm{vvt}}\right\|=\left\{\begin{array}{l}
\lambda \mathrm{S} \cdot \lambda \mathrm{e}^{\prime} \cdot \lambda \mathrm{e} \cdot \operatorname{activity}(\mathrm{e}) \wedge \text { cause }\left(\mathrm{e}^{\prime}\right)(\mathrm{e}) \wedge \mathrm{S}\left(\mathrm{e}^{\prime}\right) \\
\lambda \mathrm{S} \cdot \lambda \mathrm{e}^{\prime} \cdot \lambda \mathrm{e} \cdot \operatorname{INCEPT}\left(\mathrm{e}^{\prime}\right)(\mathrm{e}) \wedge \mathrm{S}\left(\mathrm{e}^{\prime}\right)
\end{array}\right.
$$

Вариант (3) создает каузативную структуру свершений, и глагольная группа представляет собой отношение между каузариующим и каузируемым событиями. С помощью варианта (4) деривируется структура достижений, которая представляет собой отношение между состоянием или процессом и событием, в котором они начинаются иметь место. INCEP, таким образом, следует рассматривать как событийно-семантический вариант оператора BECOME у Д. Даути. Определения INCEP мы не даем, см., например, [Piñón, 2001], где предлагается анализ весоме в событийных терминах.

Вариант (3) представлен, очевидно, у переходных глаголов типа (31b), а также, например, всех глаголов на $a$ в (19)-(21). Примером структуры, которая интерпретируется с применением варианта (4), могут служить (7) и (9).

Чтобы участвовать в дальнейшей деривации, отношение между событиями должно быть преобразовано в событийный предикат. Этого, в частности, требуют вышерасположенные операторы вида и времени. Мы предполагаем, что это происходит при помощи операторов Ext и Int, которые представляют собой денотаты признаков [Ext] и [Int]. Признаки размещаются в функциональной вершине $\mathrm{F}$, присоединяющей глагольную группу в качестве комплемента. Ее точная идентификация не имеет решающего значения. [Ext] и [Int] показаны в (37):

$$
\begin{gathered}
\text { (37) a. }\|[E x t]\|=\lambda \text { R. } \lambda \text { e. } \exists \mathrm{e}^{\prime}: \mathrm{R}\left(\mathrm{e}^{\prime}\right)(\mathrm{e}) \\
\text { b. }\|[\mathrm{Int}]\|=\lambda \text { R. } \lambda \text { e. } \exists \mathrm{e}^{\prime}: \mathrm{R}\left(\mathrm{e}^{\prime}\right)(\mathrm{e})
\end{gathered}
$$

Оба оператора обеспечивают экзистенциальное закрытие одного из аргументов отношения между событиями и создают событийный предикат. Ext связывает «внутренний» аргумент, т.е. каузируемое событие в случае (3) или инициируемое событие в случае (4). 
Int - зеркальное отражение Ext; он связывает «внешний» аргумент и оставляет семантически активным «внутренний». Int - точный аналог оператора стативизации Stat («стативизатор»), предложенного впервые в [Kratzer, 2000], a Ext - оператора Event («эвентизатор»), используемого в работах А. фон Штехова, начиная с [Paslawska, von Stechow, 2003]. Таким образом, в одном случае возникает дескрипция каузирующих/инициирующих подсобытий, в другом - каузируемых/инициируемых.

Отдельный компонент системы - механизм, ответственный за внедрение в структуру внешнего аргумента. Можно допустить, что внешний аргумент рождается в спецификаторе F. Притягательная сторона такого решения состоит в том, что оно открывает возможность увязать свойства F ([Ext] или [Int]) с наличием спецификатора. Спецификатор проецируется только в том случае, если присоединение F создает предикат «внешних» подсобытий, которые нуждаются в синтаксически реализованной информации об участнике. В противном случае «внешние» подсобытия закрываются квантором, и их аргумент в деривации не возникает (хотя, возможно, вводится с помощью адъюнктов). Вершину $\mathrm{F}$ можно тем самым отождествить с вершиной Voice, которая, судя по всему, необходима в теории по независимым соображениям [Harley, 2013]. Более подробную проработку теории ненецкого залога (а тем более общей теории залога) мы отложим на будущее. (Весьма вероятно, что в действительности для ненецкого языка за вершиной Voice следует закрепить не Ext и Int, а грамматические характеристики более высокого уровня, в частности, те, которые отвечают за выбор «типа спряжения» и его морфосинтаксическое обеспечение.)

Последнее соображение относится к морфологической стороне (34a-c). В соответствии с (34a), сегмент $\varnothing^{i}$ рассматривается как морфологическая реализация вершины $v_{\mathrm{vt}},(y) o-$ вершины F [Int], а неальтернирующие гласные - вершины F [Ext]. Вершина $v_{\text {vvt }}$ в этом случае не имеет поверхностного выражения. Возможная альтернатива состоит в том, чтобы признать возможность реализации нескольких смежных вершин одним и тем же морфологическим материалом (например, в духе наносинтаксиса [Starke, 2010]). Неальтернирующие элементы будут тогда закреплены за последовательностью $\left[v_{\mathrm{vvt}}-\mathrm{F}[\mathrm{Ext}]\right]$, a $(y) o-$ a $\left[v_{\mathrm{vvt}}-\mathrm{F}[\operatorname{Int}]\right]$.

При таком анализе альтернирующие $\varnothing^{i}$ и $y(o)$ не образуют естественный грамматический класс. Их членство в общем (мор)фонологическом классе в таком случае должно иметь не грамматическую, а фонологическую подоплеку. 
Таковы самые общие контуры анализа системы ненецких ауслаутов. Более полное описание, безусловно, нуждается в проработке дополнительных деталей, как содержательных, так и технических. В частности, (34a-c) следует распространить на те случаи, когда ауслаутные гласные соединяются не непосредственно с глагольным корнем, а с основой, содержащей, кроме него, разнообразные деривационно-морфологические элементы. Решение этой задачи, однако, остается за пределами наших заметок.

\section{8. Заключение}

Мы надеемся, что обсуждение было полезно по крайней мере в двух отношениях. Во-первых, были предложены некоторые дополнения и уточнения к сумме обобщений о деривационной морфологии ненецкого языка и месте в ней событийно-структурных морфем, расположенных в ауслауте глагольной основы. Во-вторых, появляется надежда, что семантическая интерпретация этих компонентов более предсказуема, систематична и композициональна, чем обсуждавшийся до сих пор материал позволял предположить.

\section{Библиографический список / References}

Буркова, 2010 - Буркова С.И. Краткий очерк грамматики тундрового диалекта ненецкого языка // Диалектологический словарь ненецкого языка / Под ред. Н.Б. Кошкаревой. Екатеринбург, 2010. С. 180-349. [Burkova S.I. Kratkij očerk grammatiki tundrovogo dialekta neneckogo jazyka [A concise grammatical sketch of Tundra Nenets grammar]. Ekaterinburg, 2010. Pp. 180-349.]

Гусев, 2010 - Гусев В.Ю. Стативы и декаузативы на *-w в самодийских языках // Материалы 3-й международной научной конференции по самодистике. Новосибирск, 26-28 октября 2010. Новосибирск, 2010. С. 54-65 [Gusev V.Y. Stativy i dekauzativy $\mathrm{v}$ samodijskikh yazykakh [Statives and anticausatives in Samoyedic languages]. Proceedings of the Third international conference on Samoyedic languages. Novosibirsk, 2010. Pp. 54-65.]

Недялков, Яхонтов, 1983 - Недялков В.П., Яхонтов С.Е. Типология результативных конструкций // Типология результативных конструкций (результатив, статив, пассив, перфект). Л., 1983. С. 5-41. [Nedyalkov V.P., Yakhontov S.E. Typology of resultative constructions. Tipologiya rezul'tativnykh konstruktsij (rezul'tativ, stativ, passiv, perfekt). Leningrad, 1983. Pp. 5-41.]

Татевосов, 2016 - Татевосов С.Г. Структура и интерпретация ненецкого глагола: Актантно-акциональные классы и типы спряжения // Вопросы языкознания. 2016. № 3. C. 81-114. [S.G. Tatevosov. Structure and interpretation of Tundra Nenets verbs: Eventuality types and conjugation classes. Voprosy yazykoznaniya. 2016. № 3. Pp. 81-114.]

Татевосов, 2018 - Татевосов С.Г. Несколько наблюдений об основах ненецкого глагола. Рукопись. МГУ имени М.В. Ломоносова, 2018. [S.G. Tatevosov. 
Neskol'ko nablyudeniy ob osnovah neneckogo glagola [Observations about Tundra Nenets verb stems]. Ms. Lomonsov Moscow State Univeristy, 2018.]

Терещенко, 1947 - Терещенко Н.M. Очерк грамматики ненецкого (юракосамоедского) языка. Л., 1947. [Tereshchenko N.M. Ocherk grammatiki nenezkogo (jurako-samojedskogo) jazyka [A sketch of the Nenets (Jurak-Samoyed) grammar]. Leningrad, 1947.]

Терещенко, 1965 - Терещенко Н.М. Ненецко-русский словарь. М., 1965. [Tereshchenko N.M. Nenecko-russkij slovar' [Nenets-Russian dictionary]. Moscow, 1965.]

Терещенко, 1973 - Терещенко Н.М. Синтаксис самодийских языков. Простое предложение. Л., 1973. [N.M. Tereshchenko. Sintaksis samodijskih yazykov. Prostoe predlozhenie [Syntax of Samoyedic Languages. Clausal structure] Leningrad, 1973.]

Урманчиева, 2013 - Урманчиева А.Ю. Образование форм аориста в самодийских языках // Acta Linguistica Petropolitana. Труды Института лингвистических исследований. 2013. Т. 9. № 2. С. 734-767. [Urmanchieva A.Yu. Aorist formation in Samoyedic languages. Acta linguistica Petropolitana. 2013. Vol. 9. № 2. Pp. 734-767.]

Bennett, Partee, 1978 - Bennett M., Partee B. Towards the logic of tense and aspect in English. Bloomington. Indiana, 1978.

Clark, Clark, 1979 - Clark E., Clark H. When nouns surface as verbs. Language. 1979. № 55. Pp. 767-811.

Comrie, 1976 - Comrie B. Aspect: An introduction to the study of verbal aspect and related problems. Cambridge, 1976.

Dowty, 1977 - Dowty D.R. Towards a semantic analysis of verb aspect and the English 'imperfective' progressive. Linguistics and philosophy. 1977. Vol. 1. Pp. 45-77.

Dowty, 1979 - Dowty D.R. Word meaning and Montague grammar: The semantics of verbs and times in generative semantics and in Montague's PTQ. Dordrecht, 1979.

Hale, Keyser, 2002 - Hale K., Keyser S.J. Prolegomena to a Theory of Argument Structure. Cambridge, 2002.

Harley, 2013 - Harley H. External arguments and the Mirror Principle: On the independence of Voice and v. Lingua. 2013. Vol. 28. Pp. 34-57.

Kavitskaya, Staroverov, 2010 - Kavitskaya D., Staroverov P. When an interaction is both opaque and transparent: The paradox of fed counterfeeding. Phonology. 2010. Vol. 27. Pp. 1-34.

Kratzer, 2000 - Kratzer A. Building statives. Proceedings of the 26th Annual Meeting of the Berkeley Linguistic Society. Conathan L., Good J., Kavitskaya D., Wulf A., Yu A. (eds.). Berkeley, 2000. Pp. 385-399.

Krifka et al., 1995 - Krifka M., Pelletier F.J., Carlson G.N., ter Meulen A., Link G., Chierchia G. Genericity: An Introduction. The generic book. Carlson G., Pelletier F.J. (eds.). Chicago, London, 1995. Pp. 1-124.

Lyutikova, Tatevosov, 2014 - Lyutikova E., Tatevosov S. Causativization and event structure. Causation in Grammatical Structures. Copley B., Martin F. (eds.). Oxford, 2014. Pp. 279-327.

Marantz, 1997 - Marantz A. No escape from syntax: Don't try morphological analysis in the privacy of your Own Lexicon. University of Pennsylvania Working Papers in Linguistics. 1997. Vol. 4. № 2. Pp. 201-225. 
McIntyre - McIntyre A. Denominal verbs: An overview. Word-Formation: An International Handbook of the Languages of Europe. P. Müller, I. Ohnheiser, S. Olsen, F. Rainer (eds.). Berlin, 2014. Pp. 434-450.

Nikolaeva, 2014 - Nikolaeva I. A grammar of Tundra Nenets. Berlin, 2014.

Paslawska, von Stechow, 2003 - Paslawska A.. von Stechow A. Perfect Readings in Russian. Perfect Explorations. Rathert M., Alexiadou A., von Stechow A. (eds.). Berlin, 2003. Pp. 307-362.

Piñón, 2001 - Piñón Ch. Modelling the causative-inchoative alternation. Linguistische Arbeitsberichte. 2011. Vol. 76. Pp. 273-293.

Rappaport Hovav, Levin, 1998 - Rappaport Hovav M., Levin B. Building verb meanings. The projection of arguments: lexical and compositional factors. Butt M., Geuder W. (eds.) Stanford, 1998.

Salminen, 1997 - Salminen T. Tundra Nenets inflection. Helsinki, 1997.

Salminen, 1998 - Salminen T. A morphological dictionary of Tundra Nenets. Helsinki, 1998.

Starke, 2010 - Starke M. Nanosyntax: A short primer to a new approach to language. Nordlyd. 2010. Vol. 36. № 1. Special issue on Nanosyntax. Pp. 1-6.

Taylor, 1977 - Taylor B. Tense and Continuity. Linguistics and philosophy. 1977. Vol. 1. № 2. Pp. 199-220.

Vlach, 1993 - Vlach F. Temporal Adverbials, Tenses and the Perfect. Linguistics and Philosophy. 1993. Vol. 16. Pp. 231-283.

Статья поступила в редакцию 1.07.2018

The article was received on 1.07.2018

Татевосов Сергей Георгиевич - доктор филологических наук; заведующий кафедрой теоретической и прикладной лингвистики филологического факультета, Московский государственный университет им. М.В. Ломоносова; заведующий лабораторией общей семантики Института современных лингвистических исследований, Московский педагогический государственный университет

Tatevosov Sergei G. - Dr. Phil. Hab.; Head of the Department of Theoretical and Applied Linguistics of the Philological Faculty, Lomonosov Moscow State University; Head of the Laboratory of General Semantics of the Institute of Modern Linguistic Research, Moscow Pedagogical State University

E-mail: tatevosov@gmail.com 


\section{О.Д. Черепанова}

Московский государственный университет им. М.В. Ломоносова, 119991 г. Москва, Российская Федерация

\section{Фонетические особенности немецкого и русского языков через призму скороговорок}

В статье рассматриваются результаты сопоставительного фонетического анализа немецких и русских скороговорок. Цель исследования состояла в том, чтобы выявить, в какой мере особенности звуковой системы конкретного языка находят отражение в скороговорках и насколько целесообразно использование последних при обучении произношению на иностранном языке, в том числе, в качестве материала для компьютерных произносительных тренажеров. Ключевые слова: фонетика, немецкий язык, сопоставительный анализ, скороговорки, произносительные ошибки, овладение иностранным языком.

\section{O.D. Cherepanova}

Lomonosov Moscow State University, Moscow, 119991, Russian Federation

\section{Contrastive phonetic analysis of Russian and German tongue twisters}

This article is a review of a contrastive phonetic analysis of German and Russian tongue twisters. The aim of the survey was to examine in which way tongue twisters reflect peculiarities of a language sound system and whether it is efficient to turn to tongue twisters while improving foreign language pronunciation, e.g. to use them in computer-aided pronunciation training systems. 
Key words: phonetics, German language, contrastive analysis, tongue twisters, pronunciation errors, second-language acquisition.

Данная статья посвящена фонетическому анализу немецких и русских скороговорок, оценке их произносительных трудностей: как универсальных, так и связанных с особенностями звукового состава и фонотактики русского и немецкого языков.

В Малом толковом словаре термин «скороговорка» определяется как «специально придуманная фраза с труднопроизносимым набором звуков, которую нужно произнести быстро, не запинаясь» [Лопатин, Лопатина, 1990, с. 576]. Сегодня скороговорки все чаще используются в качестве упражнений для тренировки дикции и произношения: как логопедами для коррекции и совершенствования речевого аппарата и развития артикуляторных навыков у детей, так и артистами, дикторами, теле- и радиоведущими и другими специалистами, профессия которых связана с речью на публику.

Существует много разновидностей скороговорок: короткие и длинные, рифмованные и нерифмованные, с повторами и без повторов. В нашей работе рассматриваются самые разные типы скороговорок, т.к., вне зависимости от назначения, каждый тип, так или иначе, основан на произносительных трудностях конкретного языка.

Научный интерес к скороговоркам появился лишь недавно, и тема, которой посвящена данная работа, до сих пор остается практически не изученной. В чем же ее актуальность? В то время как изучение иностранных языков становится все более востребованным, научиться правильному произношению, особенно если нет возможности общения с носителями языка, бывает довольно сложно. Скороговорки, правильно подобранные под особенности фонетической системы изучаемого языка, возможно, могли бы помочь иностранцу освоить непривычные звуковые сочетания, отсутствующие в его родном языке.

Однако существующие на сегодняшний день сборники русских скороговорок либо составлены логопедами для работы с детьми (http:// www.chertyaka.ru/skorogovorki), либо представляют собой бессистемное собрание различных, случайно выбранных скороговорок (http://www. umopit.ru/jokes/tonguetwist.htm; http://www.heilpaedagogik-info.de; http:// www.uebersetzung.at/twister/de.htm). Лингвистический анализ фонетических особенностей языка, «отражаемых» в скороговорках, мог бы помочь в дальнейшем выделять или создавать скороговорки, наиболее подходящие для специализированных сборников и произносительных тренажеров. 
Научная литература о скороговорках и их источниках крайне скудна. Несмотря на то, что скороговорки возникли в глубокой древности, первое большое собрание опубликовал в своем хрестоматийном труде В.И. Даль [Даль, 1879]. Одновременно Даль ввел уже существовавшие в быту термины «прибаутки», «скороговорки» и др. в научный язык. И все же в сборнике Даля насчитывалось всего 49 скороговорок, а предназначались они для развлечения. Лишь в XX в. скороговорки начинают создавать целенаправленно для коррекции детской речи. Здесь стоит отметить книгу И.Г. Сухина «Веселые скороговорки для “непослушных" звуков», в которой автор собрал множество (в том числе новых) скороговорок и близкий к ним речевой материал, классифицированный для работы с детьми, имеющими дефекты в произношении [Сухин, 2005].

Одной из немногочисленных научных работ, посвященных скороговоркам, является курсовая работа М. Шукшина «National-kulturelle Spezifik der deutschen Zungenbrecher» ('Национально-культурная специфика немецких скороговорок'), которую автор защитил в 2010 г. в Киеве [Shukshyn, 2010]. В ней описывается артикуляционный и фонационный аспект немецких скороговорок, а также уделяется внимание их культурному значению в немецком обществе.

В нашей работе было проанализировано 124 скороговорки на немецком языке (сайт http://www.heilpaedagogik-info.de), и 158 русских скороговорок (сайт http://www.umopit.ru/jokes/tonguetwist.htm). Прежде чем перейти к результатам анализа, кратко опишем звуковую систему немецкого и русского языков.

В рамках настоящего исследования описание звуковых систем обоих языков дается в усеченном виде на уровне сегментной фонетики. Транскрипция русских и немецких звуков приводится в терминах основных аллофонов, для фонетической записи используется система транскрипционных знаков МФА.

\section{1. Особенности звуковых систем немецкого и русского языков в сопоставлении}

Система гласных русского языка в значительной степени отличается от немецкой. В то время как русские гласные различаются по признаку подъема, ряда и лабиализации, в немецком языке есть еще один смыслоразличительный признак - долгота (cp. bitten ['bitən] 'просить'; bieten ['bi:tən] 'предлагать'). Отметим, что противопоставление немецких гласных по долготе связано с изменением их качества. Краткие гласные произносятся с меньшим напряжением, более широким открытием рта, меньшей активностью губ и языка. В связи с этим, краткие гласные 
в немецкоязычной литературе часто описываются как ненапряженные, а долгие - как напряженные [Duden, 2015].

Стоит также подчеркнуть, что в русском языке гласные подвергаются качественно-количественной редукции, в результате которой безударные гласные сокращаются по длительности и, в большинстве случаев, в слабых безударных позициях утрачивают отчетливое звучание [Кодзасов, Кривнова, 2001]. В немецком языке редуцируется только гласный $[\varepsilon]$, причем только в определенных суффиксах и окончаниях (окончания -e, -en, -er, -est и др., префиксы be-, ge-).

Системы согласных фонем в русском и немецком языках также имеют множество отличий. В первую очередь, отметим отсутствие фонологического противопоставления согласных по признаку твердости-мягкости (палатализации) в немецком языке. Кроме того, немецкие взрывные согласные (прежде всего, глухие [p], [t], [k]) произносятся с большой напряженностью и характеризуются придыханием, которое обычно отсутствует у согласных звуков в русском языке. Другим отличием немецкой звуковой системы является отсутствие долгих согласных: две одинаковые согласные буквы в слове соотносятся не с долготой соответствующей согласной фонемы, а с краткостью предшествующего гласного (сp. Ebbe ['єbə] '(морской) отлив', но eben ['e:bən] 'гладкий'; ср. русское ванна с долгим [n]). Также в немецком языке отсутствует ассимиляция согласных по глухости/звонкости, свойственная русскому

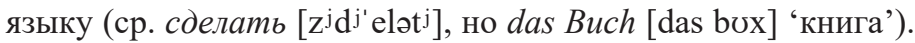

Более детально ознакомиться со звуковой системой немецкого языка можно в учебном пособии Л.И. Хицко для преподавания фонетики немецкого языка русским обучающимся [Хицко, 2011].

\section{2. Фонетический анализ немецких скороговорок}

Чтобы понять, как фонетические особенности языка отражаются в скороговорках, необходимо сначала разобраться в том, что обуславливает произносительную трудность скороговорок. Именно в этом заключалась основная задача проведенного фонетического анализа. Для всех 282 немецких и русских скороговорок были выделены фонетические явления, делающие их труднопроизносимыми. В основном, это сочетания или чередования звуков, трудные с точки зрения артикуляции либо непривычные для носителя языка; повторы части слова или слова целиком и т. д. Данные, полученные в результате анализа, представлены ниже в виде таблиц.

В следующем разделе представлены основные результаты проведенного анализа. Следует отметить, что сведения о наиболее частых произносительных сбоях в конкретных скороговорках, а также степень 
их произносительной трудности оценивались автором только на основе личного опыта и требуют дальнейшего подтверждения экспериментальными данными.

\section{1. Скороговорки на сочетания согласных}

Данные, полученные в результате анализа немецких скороговорок, представлены в таблице 1, где указано количество скороговорок, в которых чередуются указанные звуки или звукосочетания (чередование звуков обозначается знаком /).

Таблийа 1

Частота встречаемости сочетаний и чередований согласных в немецких скороговорках

\begin{tabular}{|c|c|}
\hline Сочетания и чередования согласных & Количество скороговорок \\
\hline \multicolumn{2}{|l|}{ Сибилянты } \\
\hline $\int \mathrm{p} / \int \mathrm{t} ; \mathrm{ts} / \mathrm{ks} / \mathrm{ps} / \mathrm{kst} / \mathrm{sk}$ & 9 \\
\hline $\int / \mathrm{t} \int / \mathrm{ts} / \mathrm{s}$ & 5 \\
\hline $\int / \mathrm{s} / \mathrm{z}$ & 6 \\
\hline $\int / \mathrm{t} \int / \mathrm{ts} / \mathrm{s} / \mathrm{ts}$ & 5 \\
\hline $\int 1 / \int \mathrm{r} / \int \mathrm{m} / \int \mathrm{n} / \int \mathrm{v} / \int$ & 11 \\
\hline $\mathrm{tsw} / \mathrm{ts} / \mathrm{t} \int ; \int \mathrm{w} / \int 1$ & 7 \\
\hline Итого & 43 \\
\hline \multicolumn{2}{|c|}{ Другие сочетания с сонорными } \\
\hline $\mathrm{fr} / \mathrm{fl} / \mathrm{f}$ & 11 \\
\hline $\mathrm{gr} / \mathrm{gl} / \mathrm{kr} / \mathrm{kl} ; \mathrm{br} / \mathrm{bl} / \mathrm{pl} / \mathrm{pr}$ & 9 \\
\hline $\mathrm{kr} / \mathrm{kn} / \mathrm{kl} / \mathrm{k}$ & 10 \\
\hline $\operatorname{tr} / \mathrm{kr}$ & 3 \\
\hline $\mathrm{br} / \mathrm{b}$ & 4 \\
\hline Итого & 37 \\
\hline \multicolumn{2}{|c|}{ Другие чередования } \\
\hline $\mathrm{f} / \mathrm{m} / \mathrm{w}$ & 2 \\
\hline $\mathrm{h} / \mathrm{c}$ & 1 \\
\hline И того г & 3 \\
\hline Итого всего & 83 \\
\hline
\end{tabular}


По результатам анализа можно сказать, что наиболее частыми в немецких скороговорках являются звукосочетания «шумный согласный + сонорный». Данный тип сочетаний встречается в более чем 40\% из 124 изученных в работе скороговорок. Стоит подчеркнуть, что наибольшие трудности при произнесении вызывают сочетания шумных согласных с плавными сонорными [r] и [1]. Таким образом, приведенную ниже скороговорку можно считать одной из наиболее репрезентативных:

(1) Brautkleid bleibt Brautkleid und Blaukraut bleibt Blaukraut.

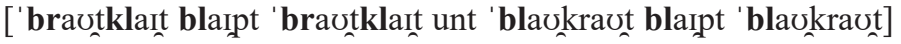

'Подвенечное платье остается подвенечным платьем, а красная капуста остается красной капустой'.

В данной скороговорке чередуются сочетания шумных взрывных согласных разного места образования с плавными сонорными [br], [bl], $[\mathrm{kr}],[\mathrm{kl}]$. Сложность артикуляции частично объясняется тем, что [b] по месту образования губно-губной, в то время как $[\mathrm{k}]$ - задненёбный. При произнесении слова Brautkleid сложность вызывают не только наличие двух разных сонорных, но и необходимость быстро сменять позицию языка: от альвеол при артикуляции [r] и [t] к мягкому небу ([k]) и обратно к альвеолам для артикуляции сонорного [1].

Из сочетаний «взрывной + сонорный» в немецких скороговорках наиболее часто встречается сочетание [kl] (таблица 2).

Таблицуа 2

Частота встречаемости сочетания «взрывной + сонорный» в немецких скороговорках

\begin{tabular}{|c|c|c|c|c|c|c|c|}
\hline & \multicolumn{6}{|c|}{ Взрывные } & \multirow{2}{*}{ Итого } \\
\hline & [p] & [b] & {$[\mathrm{t}]$} & [d] & {$[\mathrm{k}]$} & [g] & \\
\hline$+[1]$ & 15 & 20 & 1 & - & 41 & 2 & 79 \\
\hline$+[\mathrm{r}]$ & 8 & 30 & 13 & 10 & 29 & 20 & 110 \\
\hline$+[\mathrm{n}]$ & - & - & 5 & - & 21 & 0 & 26 \\
\hline Итого & 23 & 50 & 19 & 10 & 91 & 22 & 215 \\
\hline
\end{tabular}

Аналогичные артикуляционные затруднения появляются при произнесении следующей скороговорки на кластеры согласных [pl] и [kl]:

(2) Der Kaplan Klapp plant ein klappbares Pappplakat.

[dev kap'la:n klap plant Pain 'klapbarəs 'papplaka:t]

'Капеллан Клап планирует складной картонный плакат'. 
Немецкие глухие взрывные согласные произносятся с придыханием, что усложняет артикуляцию в данной скороговорке: сонорные контрастируют с придыхательными согласными.

Как видно из таблицы 1, в немецких скороговорках определенную произносительную трудность представляют также шипящие и свистящие фрикативные ([s], [z], [J]) и аффрикаты (например, [ts] и [t $\left.\left.\int\right]\right)$. Скороговорки на сибилянты встречаются очень часто, в том числе, в сочетаниях с сонорными:

(3) Zwischen zwei Zwetschgenzweigen sitzen zwei zechenschwarze tschechisch zwitschernde Zwergschwalben.

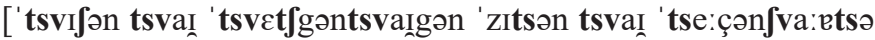

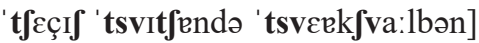

'Между двумя ветвями сливы сидят две иссиня-черные по-чешски щебечущие карликовые ласточки’.

Здесь чередуются [ts] (zwei) / [J] (zwischen) / [t $]$ ] Zwetschgen) / [z] (sitzen) и т.д.

В следующем примере артикуляцию осложняет нагромождение звукосочетаний «шипящий + сонорный» $\left[\int \mathrm{n}\right],\left[\int \mathrm{r}\right],\left[\int 1\right]$ и $\left[\int \mathrm{m}\right]$ :

(4) Schnecken erschrecken wenn sie an Schnecken schlecken, denn zum Schrecken vieler Schnecken manche Schnecken, Schnecken nicht schmecken.

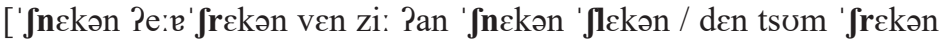

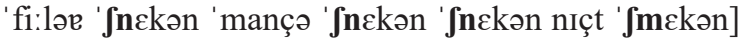

'Улитки пугаются, когда лижут улиток, так как, к ужасу многих улиток, некоторым улиткам не нравятся на вкус улитки'.

При этом Schnecken, schlecken и schmecken отличаются друг от друга только одной фонемой (сонорным, следующим за [J]), что значительно повышает вероятность произносительного сбоя именно в данных словах.

Сложность скороговорки резко повышается, если в ней одновременно сочетаются разные классы согласных:

(5) Fischers Fritze fischt frische Fische;

Frische Fische fischt Fischers Fritze.

['fifes ' fritsə fift 'frifo ' fif $\int$ /

'fri $\int \partial$ ' fif $\int \partial$ fift ' fifes 'fritsə]

'Фриц рыбака ловит свежую рыбу;

свежую рыбу ловит Фриц рыбака'. 
Данная скороговорка не зря является одной из самых известных в Германии и немецкоговорящих странах. Помимо шипящих и аффрикат ([S], [s] - Fischers, fischt, Fische; [ts] - Fritze), скороговорка в значительной степени усложняется фрикативным [f] и его сочетанием с сонорным [fr], с которых начинается каждое слово в предложении. В случае произносительного сбоя по понятным причинам произносится [frift] вместо [fIft], [fif $\int$ ] вместо [frIfə], и, наоборот, [frif $\left.\int \partial\right]$ вместо [fifə] и т.п. При этом произнесение слова Fritze кажется более легким - возможно, в связи с тем, что звук [ts] выделяет его из остальных похожих друг на друга слов.

Также часто встречаются скороговорки на звукосочетание [ks] (в немецком языке этому звуку соответствуют буквосочетания $x, c h s$ ) в чередовании с $[\mathrm{sk}]$ и $[\mathrm{x}]$ :

(6) Max macht Wachsmaskenwachs, Wachsmaskenwachs macht Max.

[maks maxt 'vaksmaskənvaks / 'vaksmaskənvaks maxt maks]

'Макс делает воск для восковых масок,

для восковых масок воск делает Макс'.

Здесь наиболее вероятны произносительные ошибки в словах Max и macht, где вместо [ks] часто произносится [xt] и наоборот. То же самое касается части слова -masken в Wachsmaskenwachs. Но произносительная трудность скороговорки заключается не только в этом. В данном предложении все слова начинаются с губно-губного [m] или губнозубного [v]. Max [maks] и Wachs [vaks] отличаются друг от друга только первой фонемой, что приводит к дополнительным оговоркам.

\section{2. Скороговорки на гласные}

Данные о гласных в проанализированных немецких скороговорках представлены в таблице 3 .

Таблий 3

Частота встречаемости гласных в немецких скороговорках

\begin{tabular}{|l|c|}
\hline \multicolumn{1}{|c|}{ Гласные } & Количество скороговорок \\
\hline \multicolumn{2}{|c|}{ По долготе } \\
\hline a / a: & 6 \\
\hline$\varepsilon /$ e: & 2 \\
\hline y / y: & 2 \\
\hline o / o: & 1 \\
\hline
\end{tabular}


Окончание таблицьы 3

\begin{tabular}{|c|c|}
\hline Гласные & Количество скороговорок \\
\hline \multicolumn{2}{|c|}{ Дифтонги } \\
\hline aṽ, aI & 2 \\
\hline \multicolumn{2}{|c|}{ Другие чередования } \\
\hline $\mathrm{a} / \varepsilon$ & 2 \\
\hline $\mathrm{e}: / \varepsilon:$ & 2 \\
\hline v / ø: & 2 \\
\hline y: / o: & 1 \\
\hline у: / a: / o: / ع и др. & 5 \\
\hline ॰ / i: / ø: & 3 \\
\hline $\mathrm{a} / \mathrm{o} / \mathrm{v}$ & 2 \\
\hline $\mathrm{i} / \mathrm{Y}$ & 1 \\
\hline Итого & 31 \\
\hline
\end{tabular}

Прежде всего, напомним, что в немецком языке гласные имеют фонологическое различие по долготе и краткости. Так, приведенная ниже скороговорка - на краткое [а], которое находится в контрасте с долгим [a:]: $\alpha \beta$ [?as] 'ел, ела' - Aas [?a:s] 'падаль'.

(7) Als Anna abends aß, aß Anna abends Ananas.

[?als '?ana ' ?abəns ?as / ?as ' ?ana ' 'abəns ?ananas]

'Когда Анна ела вечером, Анна ела вечером ананас'.

Другой особенностью немецких гласных является их достаточно тонкое различие по качеству. Гласные в немецком языке бывают открытыми и закрытыми: при этом долгие гласные обычно закрытые, а краткие - открытые. В основе следующей скороговорки лежит именно это различие:

(8) Müller Lümmer frühstückt schüsselweise grünes Gemüse.

Müller Rümmel schlürft eine Schüssel trübe Brühe.

['myle 'lyme 'fry:ftykt ' 'ysəlvaizə 'gry:nəs gə' my:zə /

'myle 'ryməl flyeft ' Painə ' Jysəl 'try:bə 'bry:ə]

'Мельник Люммер ест на завтрак мисками зеленые овощи.

Мельник Рюммель хлебает миску мутного бульона'. 
В данной скороговорке чередуются краткий [ү] (Müller, Lümmer, -stückt, schüsselweise) и долгий закрытый [у:] (früh-, grünes, Gemüse).

Возможно также и чередование открытых и закрытых долгих гласных разного типа, как в примере (9), где долгий закрытый [e:] в denen 'тем' и dehnen 'растягивать' чередуется с долгим открытым [ع:] в Dänen 'датчане':

(9) Denen Dänen, denen Dänen Dänen dehnen, dehnen deren Dänen.

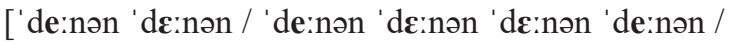

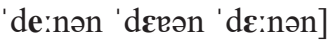

'Тем датчанам, которым датчане вытягивают датчан, вытягивают их датчан’.

Как видно из примера (10), причиной произносительной трудности может быть и контраст, основанный на огубленности/неогубленности гласных:

(10) Chinesisches Schüsselchen, chinesisches Schüsselchen, chinesisches Schüsselchen.

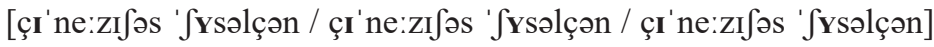

'Китайское блюдечко, китайское блюдечко, китайское блюдечко'.

Открытый неогубленный [I] в Chinesisches противопоставляется в данной скороговорке огубленному [Y] в Schüsselchen.

\subsection{1. Твердый приступ в немецком языке}

Немецкие гласные и дифтонги в начале корня (или приставки) произносятся с так называемым твердым приступом. Твердый приступ образуется из-за смыкания голосовых связок перед произнесением гласного звука. При разрыве гортанной смычки струя выдыхаемого воздуха создает шум. В немецком языке образующаяся смычка называется Knacklaut 'щелкающий звук'. Похожий звук встречается в таких русских словах, как эx, не- $а$ при их энергичном произнесении.

В немецком языке твердый приступ гласных - очень характерное явление. Он резко отделяет слово, начинающееся с гласного, от предыдущего слова, что делает немецкую речь отрывистой и резкой. Так, например, в русском языке словосочетание в отличие произносится как одно фонетическое слово, в немецком же zum Unterschied - как отдельные два слова (тем не менее, предлог zит обладает меньшей фонетической самостоятельностью, чем знаменательное слово). 
Скопление в одном предложении нескольких слов, начинающихся с твердого приступа, затрудняет произнесение скороговорки. В проанализированном материале нам встретилось 5 скороговорок на твердый приступ. Одна из них уже была представлена в примере (7), приведем еще несколько примеров:

(11) Esel essen Nesseln gern, Nesseln essen Esel gern.

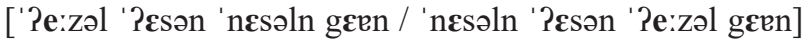

'Ослы с удовольствием едят крапиву, крапиву с удовольствием едят ослы'.

В примере (11) произнесение также затрудняет чередование долгого [е:] в Esel и короткого [ع] в essen, а также чередование согласных [s] и $[\mathrm{z}]$.

(12) In Ulm und um Ulm und um Ulm herum.

In Ulm, um Ulm und um Ulm herum.

[?in Polm Pont Pom ?olm ?ont ?om Polm he'rom //

?In Polm / Pom Polm ?ont ?ơm Polm he'rom]

'В Ульм, и около Ульма, и вокруг Ульма.

В Ульм, около Ульма и вокруг Ульма'.

Твердый приступ, с которого начинается практически каждое слово в скороговорке (12), вызывает сложности при произнесении даже у взрослых. Произносительную трудность повышает относительно малая длина слов, чередование [nt] в und с билабиальным [m] в um, в результате которого при сбое зачастую вместо [ชm] произносится [ชn]; а также чередование $[\mathrm{m}]$ и $[\mathrm{lm}]$ (в Ulm), которое при быстром произнесении может привести к пропуску звука [1].

\section{3. Фонетический анализ русских скороговорок}

\section{1. Скороговорки на сочетания согласных}

Данные о наиболее частых сочетаниях и чередованиях согласных, полученные в результате анализа русских скороговорок, представлены в таблице 4.

Как и в немецком языке, в русском существует множество скороговорок на свистящие и шипящие согласные и звукосочетания с ними. Из проанализированных скороговорок более $20 \%$ - на этот класс согласных. Не случайно одной из наиболее известных скороговорок является эта:

(13) Шла Саша по шоссе и сосала сушку.

[șla 'sașa pașa'se isa'sala 'suṣku] 
Таблица 4

Частота встречаемости сочетаний и чередований согласных в русских скороговорках

\begin{tabular}{|c|c|}
\hline Сочетания и чередования согласных & Количество скороговорок \\
\hline \multicolumn{2}{|c|}{ Сонорные (и [v]) } \\
\hline $1 / \mathrm{r} / \mathrm{n} / \mathrm{v}$ & 26 \\
\hline $\mathrm{m} / \mathrm{n} / 1 / \mathrm{b}$ & 5 \\
\hline $\mathrm{r} / \mathrm{r}^{\mathrm{j}}$ & 7 \\
\hline $1 / 1 \mathrm{j} ; \mathrm{m} / \mathrm{m}^{\mathrm{j}}$ & 4 \\
\hline Ит ого & 42 \\
\hline \multicolumn{2}{|c|}{ Сибилянты } \\
\hline 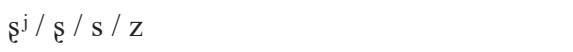 & 10 \\
\hline $\mathrm{s}^{\prime}$ & 6 \\
\hline $\mathrm{s}$ & 3 \\
\hline $\mathrm{ts} / \mathrm{tc}^{\mathrm{j}} / \mathrm{s}$ & 2 \\
\hline $\mathrm{ts}^{\mathrm{j}}$ & 8 \\
\hline$s / s^{j}$ & 6 \\
\hline $\mathrm{s} / \mathrm{z}$ & 3 \\
\hline Итого & 38 \\
\hline \multicolumn{2}{|c|}{ Другие сочетания с сонорныли (и [v]) } \\
\hline $\mathrm{pr} / \mathrm{dr} / \mathrm{tr} / \mathrm{dv} / \mathrm{kv} / \mathrm{bv}$ & 15 \\
\hline $\mathrm{br} / \mathrm{bl} / \mathrm{b}$ & 6 \\
\hline $\mathrm{pl} / \mathrm{pr}$ & 3 \\
\hline $\mathrm{kl} / \mathrm{gl} / \mathrm{kr} / \mathrm{gr} / \mathrm{g} ; \mathrm{rl}$ & 13 \\
\hline $\mathrm{fr} / \mathrm{vr} / \mathrm{rv} / \mathrm{nr} / \mathrm{pr}$ & 4 \\
\hline Итого & 41 \\
\hline \multicolumn{2}{|c|}{ Другие чередования } \\
\hline $\mathrm{b} / \mathrm{p} / \mathrm{t} / \mathrm{d} / \mathrm{k} / \mathrm{t} / \mathrm{b}^{\mathrm{j}} / \mathrm{p}^{\mathrm{j}}$ и т.д. & 5 \\
\hline Итого всего & 126 \\
\hline
\end{tabular}


Здесь чередуются фонемы [s] и [s] - как раз они часто вызывают у детей затруднения. Скороговорка (14) - на чередование [s] и [s] :

(14) Везет Сеня Саню с Соней в санках. Санки скок! Сеню - с ног, Саню - в бок, Соню - в лоб. Все в сугроб - хлоп!

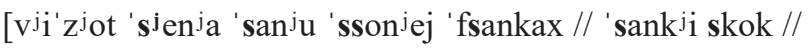

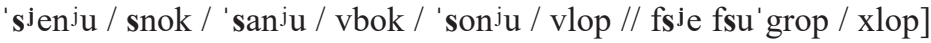

Слова, в которых чередуются вышеупомянутые звуки (Сеню, Саню, Соню и т.д.) очень похожи друг на друга, что вызывает дополнительные трудности. К произносительному сбою может также привести кластер из двух согласных [s] (с Соней).

Второй группой скороговорок на согласные, которую хотелось бы выделить, является группа на сочетание «шумный взрывной + вибрант $[\mathrm{r}]$ ». На данный тип скороговорок приходится около 15\% проанализированного материала.

(15) Краб крабу сделал грабли, подарил грабли крабу.

Грабь граблями гравий, краб!

[krap 'krabu 'zdjelal 'grabliji / pada' ${ }^{\mathrm{j}}{ }^{\mathrm{j} l}$ ' $g r a b{ }^{\mathrm{j} i}$ ' krabu // grap' grab'liamiji 'gravijij / krap]

Практически в каждом слове в данной скороговорке встречается последовательность $/ \mathrm{gr} /$ или $/ \mathrm{kr} /$, при этом взрывные $[\mathrm{k}]$ и [g] отличаются друг от друга только признаком глухости/звонкости, что увеличивает вероятность произносительного сбоя. На данном смыслоразличительном признаке построена и известная всем со школы скороговорка про дрова:

(16) На дворе трава, на траве дрова, на траве двора не коли дрова. [nadva'r ${ }^{\mathrm{j}} \mathrm{e}$ tra'va / natra' $\mathrm{v}^{\mathrm{j}} \mathrm{e}$ dra'va / natra'v ${ }^{\mathrm{j} e}$ dva'ra njika' $\left.{ }^{\mathrm{j} i \mathrm{~d}} \mathbf{d r a}{ }^{\prime} \mathrm{va}\right]$

Именно чередование звукосочетаний $/ \mathrm{dr} /, / \mathrm{tr} /$ и $/ \mathrm{dv} /$ делает скороговорку труднопроизносимой. В данной фразе стоит также выделить слова дрова и двора. В них сонорный [r] и фрикативный [v] меняются местами, обуславливая тем самым большое количество произносительных сбоев именно на этой паре слов.

Произносительная сложность скороговорок повышается, если в предложении чередуются звукосочетания не только с дрожащим [r], но и с другими сонорными, как, например, в скороговорке (17), которую часто используют логопеды для коррекции произношения у детей:

(17) Карл у Клары украл кораллы, Клара у Карла украла кларнет. [karl u'klari u'kral ka'rali / 'klara u'karla u'krala klar'n'et] 
В данном предложении трудность вызывают многочисленные кластеры «шумный согласный + плавный сонорный» и «сонорный + сонорный»: $/ \mathrm{kl} /, / \mathrm{kr} /, / \mathrm{rl} /, / \mathrm{rn} /$. Сложность заключается и в том, что сонорные примерно одного места, но разного способа образования меняются позициями (ср. украла и кларнет).

Сонорные вызывают трудности при произнесении не только в сочетании с взрывными или другими сонорными согласными. Даже в интервокальной позиции при частом чередовании [r], [1] и [v] произносительные сбои достаточно вероятны:

(18) Кавалеры к королеве припльвали в каравелле.

[kava' ljeri k kara' $\mathbf{l}^{\mathrm{j}} \mathrm{ev}^{\mathrm{j}} \mathrm{e}$ pripli'valji fkara'velje]

Помимо скороговорок на сонорные, часто встречаются скороговорки с чередованиями твердых и мягких взрывных согласных разного места образования:

(19) Купи кипу пик.

\section{[ku'p $\left.\mathbf{p}^{\mathrm{j} \mathrm{i}} \mathbf{k}^{\mathrm{j}} \mathrm{ipu} \mathbf{p}^{\mathrm{j}} \mathrm{ik}\right]$}

Несмотря на то, что фраза в примере (19) очень короткая, при ее произнесении возникают определенные трудности. В каждом из слов чередуются взрывные $[\mathrm{p}] /\left[\mathrm{p}^{\mathrm{j}}\right]$ и $[\mathrm{k}] /\left[\mathrm{k}^{\mathrm{j}}\right]$, при этом $[\mathrm{p}]$ по месту образования губно-губной, a [k] - велярный. Наиболее вероятным нам кажется сбой на слове кипу (например, вместо него говорящий может произнести «пику»).

Помимо скороговорок, произносительные трудности которых связаны с фонетическими (артикуляционными) особенностями русских согласных, существуют также скороговорки, которые просто содержат длинные слова. К данной категории можно отнести более $10 \%$ скороговорок из проанализированного материала. Очень часто длина слов в скороговорках искусственно повышается за счет одной или нескольких приставок:

(20) Деидеологизировали-деидеологизировали, и додеидеологизировались.

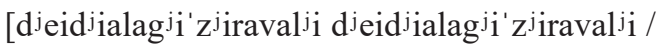

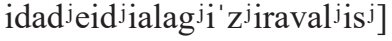

\section{2. Скороговорки на гласные}

В рассмотренном нами материале скороговорки на гласные практически отсутствуют. Скороговорок только на гласные звуки (как, например, немецкий пример (9)) нам не встретилось. Вероятно, это 
обусловлено тем, что в русском языке смыслоразличительная функция гласных достаточно невелика. Так, в примере (21) чередуются гласные звуки [i] и [i], однако данное предложение можно было бы также классифицировать как скороговорку на чередование согласных $[\mathrm{m}]$ и $\left[\mathrm{m}^{\mathrm{j}}\right]$ :

(21) Не жалела мама мыла, мама Милу мылом мыла.

Мила мыла не любила, мыло Мила уронила.

[njiZa'ljela 'mama 'mila / 'mama 'mijilu 'milam 'mila //

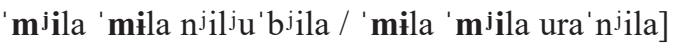

\section{4. Заключение}

В результате анализа 124 немецких и 158 русских скороговорок и сравнения наиболее частых звукосочетаний, вызывающих произносительные трудности, нами были сделаны следующие выводы.

1. В скороговорках ярко отражаются отличия русской системы гласных от немецкой. В немецком языке от долготы или краткости гласного (его открытости или закрытости) часто зависит правильное опознание слова: das Matt [mat] 'мат', der Maat [ma:t] 'старшина, приятель'. Около $25 \%$ рассмотренных немецких скороговорок - полностью или частично на гласные. Твердый приступ, присутствующий в немецком языке перед гласными в начале корня или приставки, усложняет их произнесение и является тем самым основой для построения скороговорок на гласные. В русском языке такие скороговорки практически отсутствуют.

2. В обоих языках самыми распространенными являются скороговорки на сибилянты и аффрикаты. В русском языке на данный вид скороговорок приходится около $17 \%$, в немецком - $20 \%$.

3. Сонорные звуки как в русских, так и в немецких скороговорках также часто являются причиной произносительного сбоя. Необходимо заметить, что в обоих языках к сочетаниям, наиболее проблематичным с фонетической точки зрения, относятся группы согласных «шумный взрывной + плавный сонорный» (например, $/ \mathrm{kl} /, / \mathrm{kr} /, / \mathrm{kn} /$ в немецком и $/ \mathrm{kr} /, / \mathrm{kl} /, / \mathrm{tr} /, / \mathrm{dr} /$ в русском).

4. В то время как в немецком языке основные трудности в скороговорках создают именно кластеры согласных («шумный взрывной + сонорный», «шумный сибилянт + взрывной», «шумный сибилянт + сонорный»), в русском языке существует также большое количество скороговорок, в которых нет нагромождения согласных, а идет просто их чередование в различных интервокальных позициях.

Подводя итог, отметим, что скороговорки действительно в определенной степени отражают свойства фонетической системы конкретного 
языка. Об этом свидетельствует наличие множества скороговорок на чередование гласных в немецком языке и практически полное их отсутствие среди русских скороговорок. Нам представляется, что такие скороговорки можно эффективно использовать при обучении носителей русского языка значительно более сложной системе немецких гласных звуков. При этом важно учитывать, что носители русского языка зачастую могут не слышать разницу между краткими и долгими немецкими гласными (или не обращать на нее внимания), а также забывать про приступ перед гласными в начале слога.

Чтобы работа со скороговорками была результативной, необходимо, чтобы обучающийся, во-первых, знал, на что обращать внимание при ее прочтении, а во-вторых, сразу получал обратную связь о корректности своего произношения. Возможно, в будущем в этих целях можно будет использовать компьютерные фонетические тренажеры, которые смогут автоматически оценивать произношение обучающегося, выделять неправильно произнесенные звуки и давать пользователю советы по корректировке произношения. Такие произносительные тренажеры активно разрабатываются в настоящий момент для английского языка (в англоязычной литературе их обычно называют CAPT-systems Computer Aided Pronunciation Learning systems 'система обучения произношению при помощи компьютера'). Скороговорки можно было бы использовать в качестве дополнительного материала в произносительных тренажерах для отработки произношения наиболее проблематичных для пользователя звуков. Однако для этого необходимо создание систематизированного сборника, в котором для различных проблемных звуков (пар звуков) немецкого языка были бы подобраны скороговорки, позволяющие отрабатывать их произнесение.

\section{Библиографический список / References}

Даль, 1879 - Даль В.И. Пословицы русского народа. Изд. 2-е. Т. 2. М., 1879. [Dal' V.I. Poslovitsy russkogo naroda [Proverbs of the Russian people]. 2nd edition. Vol. 2. Moscow, 1879.]

Кодзасов, Кривнова, 2001 - Кодзасов С.В., Кривнова О.Ф. Общая фонетика. M., 2001. [Kodzasov S.V., Krivnova O.F. Obshchaya fonetika [General phonetics]. Moscow, 2001.]

Лопатин, Лопатина, 1990 - Лопатин В.В., Лопатина Л.Е. Малый толковый словарь русского языка. M., 1990. [Lopatin V.V., Lopatina L.E. Malyi tolkovyi slovar' russkogo yazyka [Small explanatory dictionary of the Russian language]. Moscow, 1990.]

Сухин, 2005 - Сухин И.Г. Веселые скороговорки для «непослушных» звуков. Ярославль, 2005. [Sukhin I.G. Veselye skorogovorki dlya «neposlushnykh» zvukov [Funny tongue twisters for «naughty» sounds]. Yaroslavl, 2005.] 
Хицко, 2011 - Хицко Л.И. Практическая фонетика немецкого языка. М., 2011. [Khitsko L.I. Prakticheskaya fonetika nemetskogo yazyka [Practical phonetics of the German language]. Moscow, 2011.]

Duden, 2015 - Duden. Das Aussprachewörterbuch. 7-e Ausgabe. Kleiner S., Knöbl R. (ed.). Berlin, 2015.

Shukshyn, 2010 - Shukshyn M. National-kulturelle Spezifik der deutschen Zungenbrecher. Kiew, 2010.

Статья поступила в редакцию 15.04.2018

The article was received on 15.04 .2018

Черепанова Ольга Дмитриевна - аспирант отделения теоретической и прикладной лингвистики филологического факультета, Московский государственный университет им. М.В. Ломоносова

Cherepanova Olga D. - post-graduate student at the Department of Theoretical and Applied Linguistics of the Faculty of Philology, Lomonosov Moscow State University

E-mail: cherepanova.od@gmail.com 
Методика

\section{Н.В. Казанская}

Московский государственный областной университет, 141014 г. Мытищи, Московская обл., Российская Федерация

\section{Общие проблемы преподавания фонетики русского языка народам абхазо-адыгской группы: преодоление и устранение фонетической интерференции в условиях билингвизма}

Представленная статья посвящена вопросу преодоления фонетической интерференции. Основная цель данной работы - сопоставительный анализ фонологических систем русского и абхазо-адыгских языков, а также разработка стратегии предупреждения и преодоления интерференции родного языка в русской речи учащихся. В работе рассматриваются такие подходы к обучению русскому языку как неродному, которые делают учебный процесс более продуктивным и эффективным для учащихся. Практическая ценность представленного исследования видится в подборе основных методов и приемов в сочетании с инновационными технологиями, такими как визуализация процесса обучения, которые направлены на устранение интерференции на фонологическом уровне.

ключевые слова: фонетическая интерференция, контактирующий язык, неродной язык, акцент, консонантизм, вокализм, фонематический слух, визуализация. 


\section{N.V. Kazanskaya}

Moscow Region State University,

Mytischi, 141014, Moscow Region, Russian Federation

\section{General problems}

of teaching phonetics of the Russian language to Northwest Caucasian students:

Overcoming and eliminating phonetic interference

in the bilingual education conditions

The subject of the present article is overcoming phonetic interference. The main goal of the paper is to analyze and illustrate how the phonological systems of Russian and Northwest Caucasian languages distinguish, and then develop the strategy of lessening and avoiding mother tongue interference in pronunciation of Russian sounds. The paper examines approaches that help the teacher make the process of teaching and learning Russian as a second language (RSL) more productive and efficient for $\mathrm{L} 2$ students. This review focuses on using general language teaching methods and techniques based on innovations, such as visual means of learning that allow the elimination of interference on phonological level.

Key words: phonetic interference, contact language, second language (L2), accent, consonantism, vocalism, phonemic awareness, visualization.

\section{Введение}

Абхазо-адыгские языки относятся к северо-западной группе кавказских языков, поэтому их также называют северозападнокавказскими. Основная масса носителей абхазо-адыгских языков проживает в России (Адыгея, Кабардино-Балкария, Карачаево-Черкесия, некоторые районы Ставрополья и Кубани) и в Республике Абхазии. В современной языковой ситуации все более актуальным становится вопрос использования русского языка как родного и как неродного. В абхазо-адыгских семьях дети, наряду с национальным языком, владеют также и русским. Недостаточный развивающий потенциал русской речевой среды (общение 
дома с родителями происходит на родном языке) приводит к тому, что учащиеся часто допускают ошибки в использовании русского языка. Одна из причин - интерференция, которая заключается в привнесении определенных элементов системы родного языка в изучаемый язык. Чаще всего интерференция рассматривается как отрицательное явление, требующее коррекции и купирования.

Чтобы иметь полное понимание о проявлениях фонетической интерференции, необходимо познакомиться с фонетической системой того языка, из которого «перекочевывают» чужеродные для русского языка вкрапления. Наиболее частые ошибки кроются в неправильном восприятии звуков, которые кажутся совпадающими со звуками родной речи. Известный отечественный языковед, академик Л.В. Щерба призывал уделять этому вопросу отдельное внимание: «Особые трудности кроются даже не в тех звуках, которым нет аналогичных в родном языке учащихся, а как раз в тех, для которых в этом последнем имеются сходные звуки» [Щерба, 1963, с. 12].

\section{1. Общая характеристика фонетического строя абхазо-адыгских языков}

В типологическом отношении все абхазо-адыгские языки очень близки между собой. Их архаическая фонетика по-настоящему уникальна: базовых гласных фонем всего три: /a/, /ə/, /i/ (a, э, ы), а в абхазском, абазинском и убыхском и того меньше - всего две: /a/, /i/ (a, ы). А это значит, что при освоении русского языка, в котором 6 гласных, учащиеся столкнутся с определенными трудностями как при усвоении произносительных норм в устной речи, так и в применении орфографических правил на письме.

Необычайно бедный набор гласных компенсируется избыточным количеством согласных, которое варьируется от 45 в кабардинском языке до 80 в убыхском. По соотношению гласных и согласных с перевесом в сторону последних абхазо-адыгские языки следует поставить во главе списка предельно консонантных языков. Кстати сказать, русский язык (82\% согласных фонем) также является предельно консонантным среди славянских языков [Исаченко, 2003].

\section{1. Типологические особенности системы гласных и согласных абхазо-адыгских языков}

Фонетический минимум гласных является общей характерной чертой для всех абхазо-адыгских языков. Вспомним, что для абхазского, абазинского и убыхского языков характерен двучленный вокализм а - ы, с открытой «а» и закрытой «ы», а для адыгейского и кабардино-черкесского языков вокализм будет трёхчленным а - ы - э. 
Помимо гласных и согласных звуков, в северозападнокавказских языках встречаются полугласные, у которых нет специального графического начертания, пишутся они так же, как и гласные: $u$ [й], $y$ [ў]. Но по своим характеристикам эти звуки ближе к согласным и встречаются только перед гласными или после них, образуя дифтонги при слиянии с этими гласными: иа [йа], ои [ой], ya [ўа], oy [оў] и др. В настоящее время наблюдается преобразование дифтонгов в монофтонги, которое совершается естественным путем и отчасти под влиянием русского языка, в результате чего в абхазо-адыгских языках начинают появляться фонемы $<\mathrm{e}>,<_{\text {и }}>,<_{\mathrm{O}}>$, $<\mathrm{y}>$, но данный процесс нельзя считать завершенным [Табулова, 1976].

В абхазо-адыгских языках имеются все согласные звуки русского языка, в произношении которых различия не так существенны для восприятия на слух. Какие-то согласные могут отсутствовать в отдельно взятых языках, например, в кабардино-черкесском языке нет фонемы $<\mathrm{k}>$, что приводит к замене этой фонемы чаще всего на имеющиеся [къ], [к1], [ч], [дж] и др., а в очень редких случаях на [т] при заимствовании слов из русского языка: мужик - [мыжьыкъ], стакан - [стэчэн], корешки - [джырышкІий], килограмм - [телджырам] [Кумахов, 2006, c. 43].

Есть и специфические, так называемые кавказские звуки, в основном, согласные, отсутствующие в русском языке, для обозначения которых используются диграфы, состоящие из специальных знаков $b, b, 1$, $y$ в сочетании с основными, при этом реализуется один звук (фонема). Это ларингальные (гортанные): $1, x b$; абруптивные (надгортанные): 1 ,

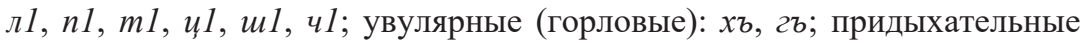
(напряженные): $n, m, \kappa y$; фарингальные (глотальные): къу: къ; латеральные (боковые): л, ль, л1; лабиализованные (огубленные): гу, гъу, жъу,

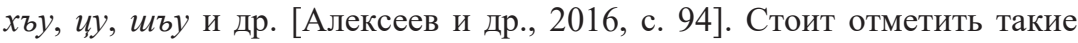
типологические согласные звуки, как альвео-палатальные «шепелявые»

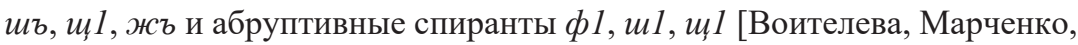
2017, с. 44-45].

Мы видим, что такой богатый арсенал согласных, по сравнению с русским языком, набирается в основном за счет добавочных признаков, таких как, например, аспирация или лабиализация, у ядерных элементов, которые в IPA (International Phonetic Alphabet, Международный фонетический алфавит) выделяются по месту и способу образования и есть практически во всех языках мира. В одной ячейке таблицы IPA оказывается сразу несколько звуков, различающихся именно этими периферийными элементами, которые не свойственны или редко встречаются в других языках. 
Казалось бы, при таком широком выборе согласных звуков не должно возникать трудностей на фонетическом уровне у носителей абхазоадыгских языков при изучении русского, по крайней мере, в отношении произношения согласных. Тем не менее, интерференция всегда будет проявляться, если в системах родного и изучаемого языка есть различия, которые можно поделить на три группы:

1) языковые явления, не имеющие аналогов в родном языке (например, отсутствие фонемы $<$ к> в кабардино-черкесском языке);

2) языковые явления, частично совпадающие в родном и изучаемом языках (например, признак твердости-мягкости согласных есть в обоих языках, но набор звуков для реализации фонемы существенно отличается, т.к. в абхазо-адыгских языках твердые согласные всегда остаются твердыми, а мягкие всегда мягкими, независимо от занимаемой ими позиции в фонетическом слове, в отличие от русского языка);

3) языковые явления, полностью совпадающие в родном и изучаемом языках (например, наличие одинаковых согласных звуков).

\section{2. Прогнозирование проблемных мест в фонетике изучаемого неродного русского языка}

Учителю обязательно нужно ознакомиться с типологическими особенностями обеих языковых систем, чтобы работать на опережение интерференции, т.е. стремиться предупреждать ее появление. Иными словами, необходимо знать, где конкретно может возникать интерферентная ошибка и как создать неблагоприятные условия для ее активации.

Несмотря на то, что всем абхазо-адыгским языкам свойственна аккомодация, редукция и выпадение гласных, эти процессы имеют несколько иной характер, нежели в русском языке. В абхазо-адыгских языках нет позиционной редукции гласных, отчего в русской речи носителей данных языков безударные гласные произносятся четко, как в позиции под ударением - получается [жаба] вместо [жаб^] и т.п.). С другой стороны, в абазинском языке, как и в абхазском, возможно выпадение гласного основы под влиянием ударения, вследствие чего появляются усеченные формы слов, в абазинском наряду с полногласными: абари 'этот'; абани 'тот'; арат, абарат 'эти'; анат, абанат 'те' - арт, ант; а в абхазском - вместо полногласных: абри 'этот', абни 'тот', арm/абамрт 'эти', анту/абамнт 'те' [Бгажба, 1988]. В кабардино-черкесском языке количественная редукция гласных наблюдается только в открытом слоге, причем возможен не только переход долгих гласных в краткие, но и наоборот, вследствие чего в русских словах долгие ударные гласные подменяются краткими: бэбушка вместо бабушка. 
Что касается произношения согласных, то трудности будут возникать при звуковых изменениях согласных в определенных позициях. Например, в абазинском и адыгейском языках конечные согласные не оглушаются, значит этот фонетический закон родного языка может отражаться в русской речи учащихся: гри[б] вместо гри[n].

И в русском, и в северозападнокавказских языках имеются твердые и мягкие согласные, но в русском языке все мягкие согласные палатализованные (кроме «й»), т.е. мягкая артикуляция является дополнительной (при подъеме средней части спинки языка к твердому небу), а в абхазо-адыгских языках мягкие согласные палатальные, т.е. мягкая артикуляция является основной и не зависит от позиции мягкого согласного в слове. Носители этих языков постоянно путают мягкие и твердые русские согласные звуки. Допуская ошибки в устной речи, учащиеся переносят их на письмо: одын вместо один, огон вместо огонь, вилька вместо вилка и т.п.

Несмотря на то, что объем раздела фонетики в школьной программе небольшой, он тесно связан с последующим изучением морфологии и синтаксиса. Поэтому учителю очень важно знать отличительные особенности контактирующих языков при работе над изучением фонетики. Также не стоит забывать, что абхазо-адыгские языки по своему грамматическому строю относятся к агглютинативному типу, следовательно, из русской речи учащихся-носителей этих языков могут выпадать флексии слов. Ярким примером этому служит тот факт, что при заимствовании северозападнокавказскими языками слов русского языка теряется окончание - $а$ : школа (рус.) - шкІол (абаз.), газета (рус.) - газет (абаз.) [Баталова, 2017, с. 196]. А для абхазского языка характерно начинать слово с префикса $a$-, который выполняет примерно такую же функцию, как определенный артикль the в английском языке, что может отражаться в русской речи абхазов: атеатр вместо театр, аспектакль вместо спектакль и т.п.

\section{2. Методы и приемы обучения правильному произношению в процессе обучения фонетике русского языка}

В педагогической литературе можно встретить определение метода как способа деятельности учителя и учащихся; как совокупности действий и приемов работы; как пути, по которому учитель ведет учащихся от незнания к знанию [Лоркипанидзе, 1957, с. 153]. Наиболее полное определение метода дает известный отечественный дидакт И.С. Лернер, понимавший под методом способ достижения цели обучения, представляющий собой систему последовательных и упорядоченных действий учителя, организующего с помощью определенных средств, 
практическую и познавательную деятельность учащихся по усвоению социального опыта [Лернер, 1976]. Прием - частное применение метода, его реализация. Причем метод может быть и приемом в другом методе, например, за основу берется имитационный метод, который реализуется с помощью артикуляционного приема, например, учащиеся повторяют за учителем (проговаривают или пропевают) сочетания согласных и гласных звуков ба-бе-би-бо-бу-был-бэ-бю; ва-ве-ви-во-ву-вblвэ-вю... Если учитель понимает, что [а] произносится слишком открыто, то для его «сужения» он может использовать артикуляционный прием, добавив новые звуковые ряды, где пара с [а] будет следовать за парой с лабиализованными [о] или [y]: бо-ба, бу-ба; во-ва, ву-ва; го-га, гу-га... Наоборот, если [а] звучит недостаточно открыто, пары с ним следует проговаривать после комбинаций пар согласных с ['э] или [и]: бе-ба,

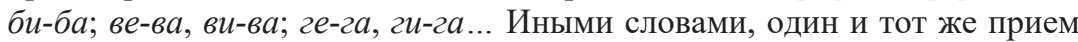
может быть элементом разных методов, а один и тот же метод, в зависимости от условий обучения, может иметь разные наборы приемов. Также один и тот же способ взаимодействия учителя и ученика в учебном процессе будет считаться методом или приемом в зависимости от того, какую функцию он выполняет. Так, визуализация может выступать самостоятельным методом, а может быть составной частью другого метода для более рационального его использования. Например, если объяснение учителя сопровождается одновременным конспектированием того же материала на доске с помощью такого приема, как скрайбинг (арт-конспектирование), то визуализация здесь функционирует как основной метод. В том случае, когда происходит обращение к визуализации в ходе другой работы, например, отсылка учащегося к инфографике во время выполнения упражнения, визуализация задействуется как прием. Совокупность же всех методов и приемов визуализации, визуально-технические способы передачи информации, структура содержания учебной информации и ее наглядное представление, а также формы визуального мышления, направленные на интенсификацию обучения, составляют технологию визуализации учебного процесса.

Для методики преподавания русского как иностранного или неродного характерно использование имитационного, артикуляционного и сопоставительного методов. Серьезный вклад в разработку данных методов внесли выдающийся российский и советский языковед, академик Л.В. Щерба, известные отечественные методисты И.Л. Бим, С.К. Фоломкина, К.М. Колосов, И.А. Грузинская и др. В разных источниках имитационный, артикуляционный и сопоставительный методы рассматриваются как приемы [Алиева, 2000] и как подходы [Шибко, 2015], причем в некоторых контекстах термины метод и подход употребляются как синонимы [Сакаева, Баранова, 2016]. 


\section{1. Сущность и функциональная направленность имитационного, артикуляционного и сопоставительного методов}

Имитационный метод основан на подражании, копировании говорящимся и заключается в том, что во время урока учитель четко произносит, а затем просит повторять за ним слоги, слова, фразы. Иногда данный вид работы требует многократного повтора, и формат урока не всегда позволяет полностью реализовать имитационный метод. Чтобы не свести использование метода к применению его лишь как приема обучения, крайне важным автору статьи видится обучение учащихся самостоятельной работе над правильностью русского произношения с привлечением возможностей интернет-ресурсов. В первую очередь, для тренировки произношения можно порекомендовать сайт Forvo, который дает возможность не только услышать практически любое слово на выбранном языке, записанное носителем, но и проверить качество своего собственного произношения, записать и послушать его в разделе «Произношение». Чтобы правильно произносить звуки, важно научиться их слышать. Если какие-то звуки русского языка не даются учащемуся, возможно, он, будучи носителем абхазоадыгской группы языков, пропускает их через фильтр родного языка и не может ухватить нюансы. На отработку конкретных звуков русского языка полезно создавать колоды минимальных пар слов на развитие фонематического слуха со звуковыми файлами для Anki, программы, позволяющей прочно запоминать информацию с помощью интервальных повторений.

Артикуляционный метод нацелен на сознательное усвоение произносительных норм и корректировку произношения учащихся, он не сводится к простому дифференцированному подражанию. Здесь учитель не только показывает, но и объясняет, как нужно правильно произносить, делая акцент на положение и движение органов речи во время артикуляции отдельного звука. Не всегда получается объяснить или ощутить, как порождается звук. В этом случае следует прибегнуть к приему использования звуков-помощников. Эти опорные звуки образуются с помощью одинаковых движений тех же органов речи, что и проблемный звук. Для постановки твердых русских звуков [ж] и [ш], при произношении которых поднятие задней части спинки языка вверх не ощущается, используются согласные звуки-помощники [г], [к], [х] и гласные $[\mathrm{o}],[\mathrm{y}]$, образующиеся при поднятой задней части спинки языка. Произнесение с напряжением сочетаний этих звуков с [ж] и [ш] помогает поднять нужную часть языка вверх и ощутить это движение. Комбинации звуков могут быть следующими: гжо, гжу, ожо, ужу; кшо, кшу, ошо, ушу; хжо, хжу; хшо, хшу. Отработать [ц] помогут 
звуки-помощники [т] и [д], стоящие в разных словах перед $u$ : двадц̧ать,

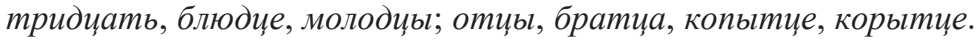

Учителю-словеснику обязательно нужно уделять пристальное внимание анализу орфоэпических и орфографических ошибок, которые являются следствием неправильного произношения. Нельзя оставлять ни единой неисправленной или необъясненной ошибки ни в устной, ни в письменной речи. После проверки письменной работы необходимо каждый раз проводить работу над ошибками с подробными комментариями и разбором явлений интерференции. При неправильном произношении слов с проблемными русскими звуками важно не только поправлять и объяснять ошибку, но и пытаться ее устранять, добиваясь сознательного управления артикуляцией. Достаточно эффективно будет использование различных приемов визуализации для создания яркого образа нормы употребления твердых и мягких согласных, например, можно повесить на стену в классе два плаката: на одном поместить изображение всегда твердых [ж], [ш], [ц] на деревянной твердой скамейке; на другой - гласные буквы $e, \ddot{e}, u, ю, я$, а также $b$ на мягком диване, именно перед этими буквами согласные звуки становятся мягкими, на кресло рядом можно «посадить» всегда мягкие согласные звуки [й’], [ч'], [щ'] - получается простая, но действенная ассоциативная памятка.

Сопоставительный метод строится на сравнении фонетико-фонологических систем контактирующих языков с помощью выделения сходств и отличий:

1) звуки русского языка, которых нет в родном языке;

2) звуки похожие, но не тождественные в разных языках;

3) звуки, совпадающие в обоих языках.

Этот метод призван помогать учащимся находить точки соприкосновения в двух языковых системах и ориентироваться на них при изучении русского языка. Например, в кабардино-черкесском языке отсутствует взрывной $[г]$, но есть фрикативный $\left[\Gamma^{\mathrm{x}}\right]$, который сохранился в южнорусских диалектах, а также допускается в некоторых словах: Господи, Бог, бухгалтер, ага, угу, ого. Для тренировки взрывного [г] целесообразно разучивать с учащимися скороговорки с этим звуком, предварительно проанализировав фонетические явления, которые встретились в тексте, и сравнив, как они проявляют себя в родном языке.

Говорил попугай попугаю: «Я тебя, попугай, попугаю!». Отвечает ему попугай: «Попугай, попугай, попугай!». Эта скороговорка, помимо проработки взрывного [г], интересна наличием омоформ: nonyzaй, nonyгаю (сущ.) - попугай, попугаю (гл.).

На дворе галка, на берегу - галька. Здесь также прорабатываем чередование твердого и мягкого [л] - [л’], причем в кабардино-черкесском языке [л] имеет промежуточное звучание между русскими [л] и [л’]. 
Нёс Григорий пирог через порог. Встал на горох и упал на порог. На примере этой скороговорки показывается оглушение [г] на конце слова, а в абхазо-адыгских языках не происходит оглушения согласных в данной позиции. Также учитель может показать разницу между [г], [к], $[\mathrm{x}]$ и $\left[\Gamma^{\mathrm{x}}\right]$, обратив внимание и на слово горох, а также провести параллель со словом бог, в котором не произойдет оглушения последнего согласного, иначе получится другое слово - бок, однако произойдет его замена на фрикативный $\left[\Gamma^{x}\right]$, который имеет промежуточное звучание между русскими $[г]$ и $[\mathrm{x}]$.

В данном случае опора на материал родного языка рассматривается как позитивная трансференция, а это не что иное, как положительное проявление интерференции. С другой стороны, сопоставительный метод направлен на вычленение инородных для русского языка элементов, привносимых из родного языка, и избавление от них как от негативной трансференции, вызывающей интерферентные ошибки.

\section{2. Сочетание методов и приемов,} направленных на предупреждение и устранение фонетической интерференции

Работа над произношением на русском как втором языке всегда будет ориентирована, в первую очередь, на формирование и развитие фонематического слуха. Фонематический слух - это способность слышать, воспринимать, узнавать, различать и воспроизводить отдельные звуки или фонемы. А без этого невозможно уловить смысл сказанного, особенно в тех случаях, когда слова или словоформы схожи по звучанию.

Артикуляция звука, его звучание и восприятие на слух взаимосвязаны: если неправильно услышать звук, то нельзя правильно его произнести. Поэтому начинать тренировать аудирование следует с простых упражнений на узнавание конкретного звука в слове. Зная, что современные школьники - это визуалы, запоминающие яркие образы, краткие цепляющие заголовки, эффектную раскадровку и т.п., учителя на уроках все чаще прибегают к разным приемам визуализации процесса обучения [Лапшева, Храмова, 2011, с. 53-56].

Применение игровых приемов усиливает эффект метода визуализации. Очень простое в исполнении, но достаточно полезное для развития фонематического слуха упражнение «Мухобойка». Задание состоит в том, что учащиеся должны сделать хлопок, когда слышат определенный звук, ассоциируя этот звук с мухой, которую мы ловим мухобойкой. Мы можем отработать любые проблемные звуки в этом упражнении, возьмем, например, слова со звуком [к]. В данной работе ранее упоминалось о том, что в кабардино-черкесском языке не имеется фонемы <к>, значит, учащихся-черкесов нужно научить слышать ее, а потом 
и произносить. Заготовим заранее слова с этим звуком: каникульл, урок, книга, ручка, учебник, карандаш, доска, окно, потолок, класс, маркер, звонок (буква, обозначающая звук [к], должна быть выделена шрифтом).

Другое упражнение, «Прогноз погоды», с использованием тех же самых слов, нацелено на определение места звука [к] в слове. Здесь мы будем использовать такой прием, как скрайбинг, т.е. в процессе выполнения упражнения на доске будет появляться графическая зарисовка, представляющая собой арт-конспект всего сказанного. Для слов, в которых [к] стоит в начале, учитель закрашивает первый квадратик из трех пустых (рис. 1), обозначенных на шкале; к нему пририсовываем облако и вписываем в него слова, начинающиеся на к - «облачно в начале дня». Если [к] встречается в середине слова, закрашиваем центральный квадратик, пририсовываем теперь к этой шкале облако и вписываем в него все слова, где «к» стоит не в конце и не в начале - «облачно в середине дня». То же делаем со словами, в которых [к] - конечный согласный: закрашиваем последний квадратик, пририсовываем к нему облако, вписываем в него слова с «к» на конце - «облачно в конце дня».

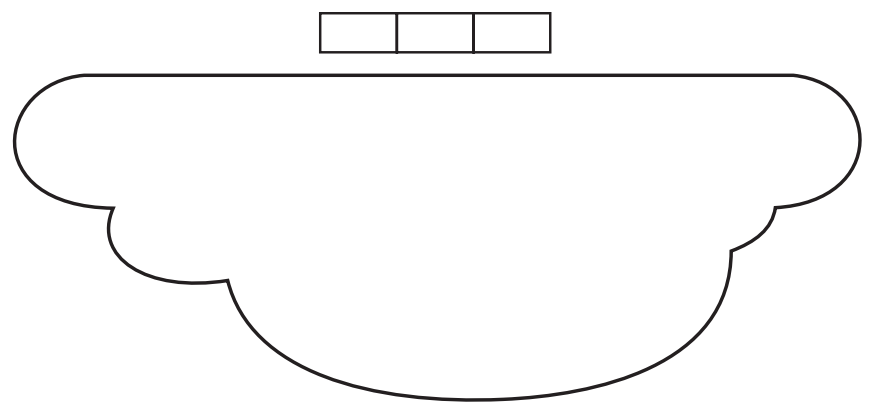

Рис. 1. Упражнение «Прогноз погоды»

Игровые приемы помогают создать ситуацию реальности, пусть даже игровой, сделать условия выполнения упражнения более естественными [Milenski, 2004, p. 21-27]. Например, в игре «Я иностранец» не только учитель, но и учащиеся могут примерить на себя роль человека, говорящего с акцентом, а чужие ошибки замечаются быстрее, чем свои собственные, благодаря чему легче усваивается произносительная норма. Правила игры просты. Учитель, или в дальнейшем ученик, играющий иностранца, рисует на доске предмет, в названии которого содержатся звонкие согласные звуки, имеющие глухие пары; остальные участники называют этот предмет вслух. «Иностранец» пытается повторить слово, но постоянно оглушает звонкие, на что класс может реагировать 
возмущенным топотом. Наконец, «иностранец» произносит слово абсолютно правильно и награждается аплодисментами. Можно брать такие цепочки: терево - дерефо - терефо - дерево; горота - корода - корота - города; порода - борота - порота - борода; федро - ветро фетро - ведро; сабор - запор - сапор - забор и т.п. Данное упражнение показывает, что неправильное произношение звука может не просто затруднить понимание, но и исказить смысл. Это мы наблюдали при произнесении слова забор с иностранным акцентом, в одном из вариантов мы получили слово, имеющееся в русском языке, но обозначающее совершенно другой объект, запор (или сабор, воспринимаемое на слух как собор). Для более полного понимания значения слов следует заготовить заранее наглядный материал - картинки к каждому слову. Некоторые цепочки неправильно произносимых слов можно продолжить с помощью замены мягкого согласного звука на твердый: [тэ]рево $\left[m^{\prime} э\right]$ рево - $[$ дэ]рефо - [d'э]рефо - терефо - дерево .

Правило мягкости-твердости перед гласными легче запоминается, когда оно опирается на такой прием метода визуализации, как составление интеллект-карт (mind maps). Такой графический способ объяснения материала урока очень похож на то, как обрабатывает информацию наш мозг. Британский психолог Тони Бьюзен, автор интеллект-карт, сделал их схематически похожими на процесс мышления, показывая его не линейную, а многомерную радиантную структуру [Buzan, 2004]. В интеллект-карте из центра, служащего для обозначения основной идеи, выходят в разные стороны лучи, связанные непосредственно с центральным понятием. Составим простейшие интеллект карты на правило обозначения мягкости (рис. 2) и твердости (рис. 3) на письме перед гласными. Лучи тоже могут разветвляться, если они связаны с другими вопросами второстепенного характера. Мы сможем разветвлять лучи наших интеллект-карт, добавляя слова-примеры на каждый конкретный случай применяемого правила, причем положение согласного перед гласным будет меняться: в первом, втором, третьем, последнем слоге. Так, от «А» (рис. 2) могут отходить лучи-слова: вагон, батарея, шоколадка, пенал и др.; от «Е» (рис. 3) - такие слова, как: перемена, осень, день, учитель, буфет и др.

Как мы видим, визуализация и наглядность не всегда обозначают одно и то же. Последнее часто носит исключительно иллюстративный характер, тогда как визуализация всегда выполняет более сложную, комплексную функцию. Точное определение метода визуализации сформулировано известным российский психологом А.А. Вербицким: «Процесс визуализации - это свертывание мыслительных содержаний в наглядный образ; будучи воспринятым, образ может быть развернут 
и служить опорой адекватных мыслительных и практических действий» [Вербицкий, 1991, с. 110].

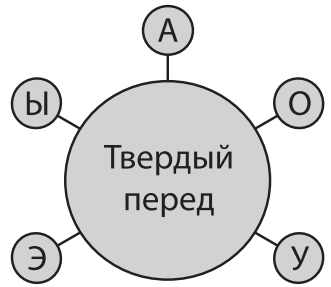

Рис. 2. Обозначение твердости согласных

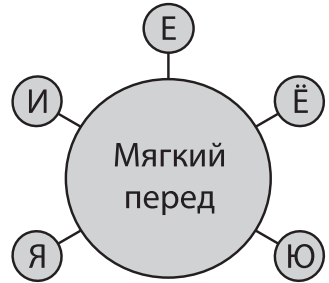

Рис. 3. Обозначение мягкости согласных

Примерами наглядности могут служить простые схемы и таблицы, которые составляются в процессе выполнения упражнений. Для профилактики и коррекции интерференции, связанной с произношением гласных под ударением, эффективными будут следующие тренировочные упражнения.

1. Выпишите слова в две колонки: в левую с ударным [э], в правую с ударным [и]: хлеб, мир, веер, свет, пир, сапфир, тема, кумир, свет, упражнение, тариф, музей, синий, малина. (Могут встречаться ошибки типа $x л[u] б$ вместо $х л[э] б$.

2. Поставьте ударение в парах слов и обратите внимание, что на один или на разные слоги ударение падает в однокоренных и похожих словах: холодный - холодильник, балерина - балетный, пастушок - поступок, ученица - учебник, рукава - нарукавник, около - молоко, дерево деревья. Составьте схемы, показывая, на какой слог падает ударение в каждом слове пары, например, слово - словарь (____ _ _ ).

3. Образуйте от следующих слов новые слова с тем же корнем:

a) с тем же самым ударяемым гласным;

б) с другим ударяемым гласным друг, круг, звон, рукав, холод, вход, место, каблук, стол, груз.

Запишите результаты в таблицу (табл. 1).

Таблийа 1

Ударение в однокоренных словах

\begin{tabular}{|c|c|}
\hline $\begin{array}{c}\text { Родственные слова } \\
\text { с ударением на один слог }\end{array}$ & $\begin{array}{c}\text { Родственные слова } \\
\text { с ударением на разные слоги }\end{array}$ \\
\hline мороз - морозныци & мороз - морозильник \\
\hline
\end{tabular}


В последнем упражнении следует несколько слов выборочно давать учащимся для фонетического разбора, чтобы они умели наблюдать и анализировать количественную редукцию гласных в безударной позиции.

Для каждой аудитории, где изучается русский язык как неродной, будет характерен определенный набор типичных интерферентных ошибок на фонетическом уровне. Эффективность преподавания русского языка в классах с многонациональным составом учащихся во многом зависит от организации процесса обучения с учетом билингвальных характеристик определенного этнического состава.

\section{Заключение}

Знание русского языка - это практическая необходимость для всех граждан РФ, поэтому все нерусское население страны в определенной степени владеет русским языком, что способствует распространению и функционированию национально-русского двуязычия в государстве.

Сегодня, вследствие активных миграционных процессов во многих регионах России, все чаще совместно обучаются русскоязычные дети, а также дети с родным (нерусским) и русским (неродным) языком обучения. Обучение в многонациональных классах становится больше правилом, нежели исключением. Явление билингвизма представляет собой одну из основных форм существования, когда в условиях разноязычия национальная и языковая ограниченность становится невозможна. Тем не менее, в результате взаимодействия фонетических систем контактирующих языков часто происходит искажение звукового состава русского слова при его воспроизведении под влиянием фонетических законов родного языка.

Изучение и сопоставление фонетических систем русского и абхазоадыгских языков наряду с анализом ошибок, допускаемых учащимися на фонетическом уровне, помогут учителю:

1) понять суть интерференции в конкретных условиях русско-северозападно-кавказского двуязычия;

2) выявить закономерности отклонения от произносительной нормы на базе имеющихся различий звукового строя национального родного и русского неродного языков;

3) выстроить учебный процесс с учетом возникающих при обучении русскому языку трудностей и возможных путей их преодоления. 


\section{Библиографический список / References}

Алексеев и др., 2001 - Языки мира: Кавказские языки / Под ред. М.Е. Алексеева, Г.А. Климова, С.А. Старостина, Я.Г. Тестельца. М., 2001. [Yazyki mira: Kavkazskie yazyki [Languages of the World: Caucasian Languages]. M.E. Alekseev, G.A. Klimov, S.A. Starostin, Ya.G. Testelets (eds.). Moscow, 2001.]

Алиева, 2000 - Алиева Н.Г. Формирование и развитие русской речи в связи с обучением произношению в начальных классах аварской школы: Дис. ... канд. пед. наук. Махачкала, 2000. [Alieva N.G. Formirovanie i razvitie russkoj rechi v svyazi s obucheniem proiznosheniyu v nachal'nykh klassakh avarskoj shkoly [Formation and enriching of children's Russian speech at mastering the literary pronunciation classes in Avar primary school]. PhD diss. Makhachkala, 2000.]

Баталова, 2017 - Баталова Е.М. Вопросы изучения фонетики абазинского языка в школе // Филологические науки. Вопросы теории и практики. 2017. № 12 (78). Ч. 1. C. 195-199. [Batalova E.M. Phonetic problems of the Abaza language encountered in schools. Filologicheskie nauki. Voprosy teorii i praktiki. 2017. № 12 (78). Part 1. Pp. 195-199.]

Бгажба, 1988 - Бгажба Х.С. Труды. Книга вторая: Исследования и очерки. Сухуми, 1988. [Bgazhba X.S. Trudy. Kniga vtoraya: Issledovaniya i ocherki [Scientific works. Book two: Studies and essays]. Sukhumi, 1988.]

Вербицкий, 1991 - Вербицкий А.А. Активное обучение в высшей школе: контекстный подход. М., 1991. [Verbitskij A.A. Aktivnoe obuchenie v vysshej shkole: kontekstnyj podkhod [Active learning at Universities: Context approach]. Moscow, 1991.]

Воителева, Марченко, 2017 - Воителева Т.М., Марченко О.Н. Обучение русскому языку как неродному: Учебно-методическое пособие. М., 2017. [Voiteleva T.M., Marchenko O.N. Obuchenie russkomu yazyku kak nerodnomu [Teaching Russian as a second language]. Teaching aid. Moscow, 2017.]

Исаченко, 2003 - Исаченко А.В. Грамматический строй русского языка в сопоставлении со словацким. Морфология. М., 2003. [Isachenko A.B. Grammaticheskij stroj russkogo yazyka v sopostavlenii so slovatskim. Morfologiya. [Grammatical system of the Russian language in relation to the Slovak language. Morphology]. Moscow, 2003.]

Кумахов, 2006 - Кабардино-черкесский язык / Под ред. М.А. Кумахова. Нальчик, 2006. T. I. [Kabardino-cherkesskij yazyk. [Kabardino-Circassian language]. M.A. Kumakhov (ed.). Nal'chik, 2006. Vol. I.]

Лапшева, Храмова, 2011 - Лапшева Е.Е., Храмова М.В. Развитие визуальной грамотности обучаемых средствами информационно-коммуникационных технологий // Психолого-педагогический журнал Гаудеамус. 2011. Т. 2. № 18. C. 53-56. [Lapsheva E.E., Khramova M.V. Development of visual literacy of learners by means of information and communication technologies. Psikhologo-pedagogicheskij zhurnal Gaudeamus. 2011. Vol. 2. № 18. Pp. 53-56.]

Лернер, 1976 - Лернер И.Я. Дидактическая система методов обучения. М., 1976. Вып. 3. (Сер. «Педагогика и психология»). [Lerner I.Ya. Didakticheskaya sistema metodov obucheniya [Didactic system of teaching methods]. Moscow, 1976. Issue 3. (Series «Pedagogika i psikhologiya»).] 
Лоркипанидзе, 1957 - Лоркипанидзе Д.О. Принципы организации и методы обучения. М., 1957. [Lorkipanidze D.O. Printsipy organizatsii i metody obucheniya [Principles of the organization and teaching methods]. Moscow, 1957.]

Сакаева, Баранова, 2016 - Сакаева Л.Р., Баранова А.Р. Методика обучения иностранным языкам. Казань, 2016. [Sakaeva L.R., Baranova A.R. Metodika obucheniya inostrannym yazykam [Methods of teaching foreign languages]. Kazan', 2016.]

Табулова, 1976 - Табулова Н.Т. Грамматика абазинского языка. Фонетика и морфология. Черкесск, 1976. [Tabulova N.T. Grammatika abazinskogo yazyka. Fonetika i morfologiya [Grammar of the Abaza language. Phonetics and Morphology.] Cherkessk, 1976.]

Шибко, 2015 - Шибко Н.Л. Общие вопросы методики преподавания русского языка как иностранного: Учебное пособие для иностранных студентов филологических специальностей. СПб., 2015. [Shibko N.L. Obshhie voprosy metodiki prepodavaniya russkogo yazyka kak inostrannogo [General questions of the methodology of teaching Russian as a foreign language]. Textbook for foreign students of philological specialties. St. Petersburg, 2015.]

Щерба, 1963 - Щерба Л.В. Фонетика французского языка. Очерк французского произношения в сравнении с русским. М., 1963. [Shherba L.V. Fonetika frantsuzskogo yazyka. Ocherk frantsuzskogo proiznosheniya v sravnenii s russkim [Phonetics of the French language. French pronunciation profile in relation to the Russian language]. Moscow, 1963.]

Buzan, 2004 - Buzan T. The mind map handbook: The ultimate thinking tool. New York, 2004.

Milenski, 2004 - Milenski Iv. Development and supervision of games in mentally retarded children. Special education. 2004. № 1. Pp. 21-27.

Статья поступила в редакцию 26.08.2017

The article was received on 26.08.2017

Казанская Наталья Владимировна - аспирант кафедры методики преподавания русского языка и литературы факультета русской филологии Историкофилологического института, Московский государственный областной университет, г. Мытищи Московской обл.; руководитель, студия английского языка «English \& I», г. Москва

Kazanskaya Natalia V. - post-graduate student at the Department of Methods of Teaching Russian Language and Literature of the Historical-Philological Institute, Moscow Region State University, Mytischi, Moscow Region; Head teacher, English \& I Studio, Moscow

E-mail: english-and-i@mail.ru 
Издание подготовили к печати:

Rhema. Рема редактор А. А. Козаренко, корректор А. А. Алексеева, обложка, макет, 2018.3 компьютерная верстка Н. А. Попова

|

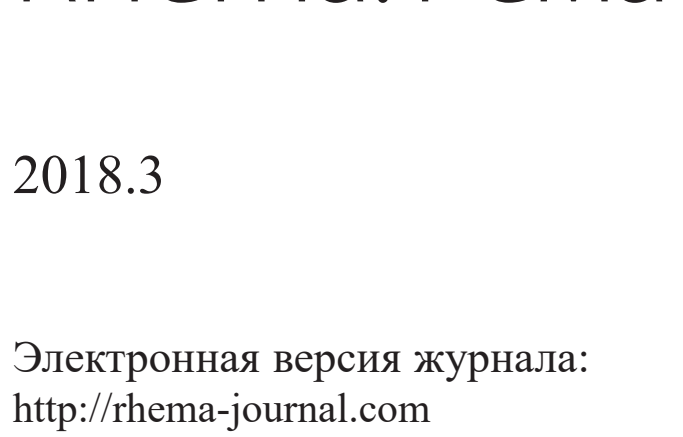

Подписано в печать 19.09.2018 г.

Формат 60×90 1/16. Гарнитура «Times New Roman».

Объем 9,5 п. л. Тираж 1000 экз. 